PNL-4604

NUREG/CR-3136

PNL-4604

\title{
Aquifer Restoration at In-Situ Leach Uranium Mines: Evidence for Natural Restoration Processes
}

Prepared by W. J. Deutsch, R. J. Serne, N. E. Bell, W. J. Martin

Pacific Northwest Laboratory

Operated by

Battelle Memorial Institute

Prepared for

U.S. Nuclear Regulatory

Commission 
This report was prepared as an account of work sponsored by an agency of the United States Government. Neither the United States Government nor any agency thereof, or any of their employees, makes any warranty, expressed or implied, or assumes any legal liability of responsibility for any third party's use, or the results of such use, of any information, apparatus, product or process disclosed in this report, or represents that its use by such third party would not infringe privately owned rights.

\section{Availability of Reference Materials Cited in NRC Publications}

Most documents cited in NRC publications will be available from one of the following sources:

1. The NRC Public Document Room, 1717 H Street, N.W. Washington, DC 20555

2. The NRC/GPO Sales Program, U.S. Nuclear Regulatory Commission, Washington, DC 20555

\section{The National Technical Information Service, Springfield, VA 22161}

Although the listing that follows represents the majority of documents cited in NRC publications, it is not intended to be exhaustive.

Referenced documents available for inspection and copying for a fee from the NRC Public Document Room include NRC correspondence and ir.ternal NRC memoranda; NRC Office of Inspection and Enforcement bulletins, circulars, information notices, inspection and investigation notices; Licensee Event Reports; vendor reports and correspondence; Commission papers; and applicant and licensee documents and correspondence.

The following documents in the NUREG series are available for purchase from the NRC/GPO Sales Program: formal NRC staH and contractor reports, NRC-sponsored conference proceedings, and NRC booklets and brochures. Also available are Regulatory Guides, NRC regulations in the Code of Federal Regulations, and Nuclear Regulatory Commission /ssuances.

Documents available from the National Technical Information Service include NUREG series reports and technical reports prepared by other federal agencies and reports prepared by the Atomic Energy Commission, forerunner agency to the Nuclear Regulatory Commission.

Documents available from public and special technical libraries include all open literature items, such as books, journal and periodical articles, and transactions. Federal Register notices, federal and state legislation, and congressional reports can usually be obtained from these libraries.

Documents such as theses, dissertations, foreign reports and translations, and non-NRC conference proceedings are available for purchase from the organization sponsoring the publication cited.

Single copies of NAC draft reports are available free upon written request to the Division of Technical Information and Document Control, U.S. Nuclear Regulatory Commission, Washington, DC 20555.

Copies of industry codes and standards used in a substantive manner in the NRC regulatory process are maintained at the NRC Library, 7920 Norfolk Avenue, Bethesda, Maryland, and are available there for reference use by the public. Codes and standards are usually copyrighted and may be purchased from the originating organization or, if they are American National Standards, from the American National Standards Institute, 1430 Broadway, New York, NY 10018.

GPO Printed copy price: $\$ \$ 5.50$ 
NUREG/CR-3136

PNL-4604

RU

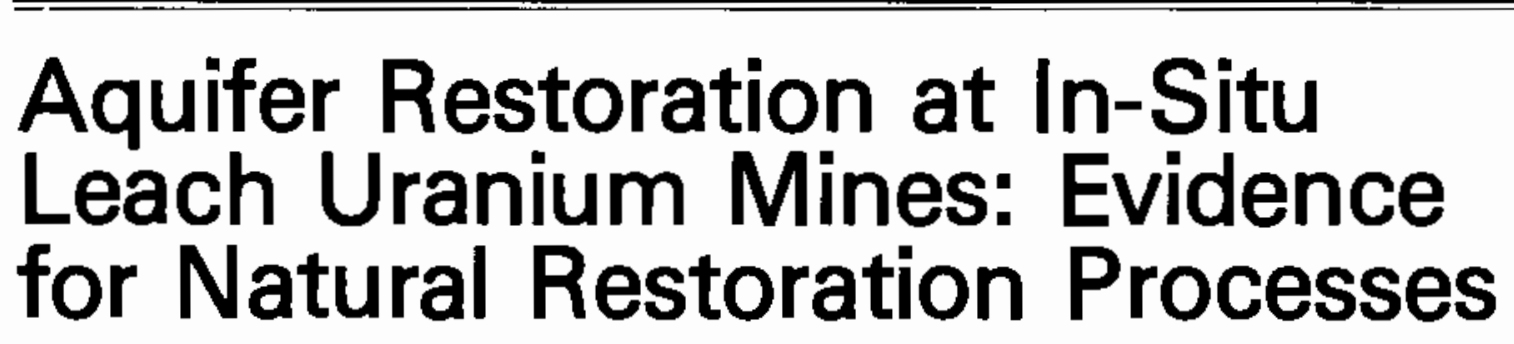

Manuscript Completed: March 1983

Date Published: April 1983

Prepared by

W. J. Deutsch, R. J. Serne, N. E. Bell, W. J. Martin

Pacific Northwest Laboratory

Richland, WA 99352

Prepared for

Division of Health, Siting and Waste Management

Office of Nuclear Regulatory Research

U.S. Nuclear Regulatory Commission

Washington, D.C. 20555

NRC FIN B2379 



\section{ABSTRACT}

Pacific Northwest Laboratory conducted experiments with aquifer sediments and leaching solution (lixiviant) from an in-situ leach uranium mine. The data from these laboratory experiments and inforination on the normal distribution of elements associated with roll-front uranium deposits provide evidence that natural processes can enhance restoration of aquifers affected by leach mining. Our experiments show that the concentration of uranium (U) in solution can decrease at least an order of magnitude (from 50 to less than $5 \mathrm{ppm} U$ ) due to reactions between the lixiviant and sediment, and that a uranium solid, possibly amorphous uranium dioxide, $\left(\mathrm{UO}_{2}\right)$, can limit the concentration of uranium in a solution in contact with reduced sediment. The concentrations of As, Se, and Mo in an oxidizing lixiviant should also decrease as a result of redox and precipitation reactions between the solution and sediment.

The lixiviant concentrations of major anions (chloride and sulfate) other than carbonate were not affected by short-tem (less than one week) contact with the aquifer sediments. This is also true of the total dissolved solids level of the solution. Consequently, we recommend that these solution parameters be used as indicators of an excursion of leaching solution from the leach field.

Our experiments have shown that natural aquifer processes can affect the solution concentration of certain constituents. This effect should be considered when guidelines for aquifer restoration are established. 



\section{ACKNOWLEDGMENTS}

This research was supported by the Methods of Minimizing Ground-Water Contamination from In-Situ Leach Uranium Mining Project conducted by Pacific Northwest Laboratory (PNL). The project is sponsored by the office of Nuclear Research of the Nuclear Regulatory Commission. We wish to acknowledge the guidance of Colleen 0strowski (NRC-Research) and John Linehan and Jeff Pohle (NRC-NMSS).

We wish to acknowledge the management efforts of the PNL Uranium Mill Tailings Program office, particularly Lysle Schwendiman and Mike Foley.

The following PNL staff contributed in the designated areas:

Andrew R. Felmy

Tom R. Gariand John W. Shade

Alan W. Lautensleger

Donald E. Rinehart

Thomas G. Walker

Marvin J. Mason

Clark 0. Harvey

Brenda K. Marshall

Glendon W. Gee
Geochemical modeling and experimental design Sample collection and field analyses

$X-r a y$ diffractometry

Ion chromatography

Inductively coupled plasma spectroscopy

Inductively coupled plasma spectroscopy

Atomic absorption spectroscopy

Pulsed laser fluorimetry

Technical editing

Technical review

We wish to acknowledge the efforts of Uranium Resources Incorporated (URI) in helping collect sediment, lixiviant, and water samples at their Benavides site in southern Texas. Bill McKnight, Kelly Biddle, and Steve Lampkins of URI are specifically acknowledged.

Finally, the efforts of our subcontractor, U.S. Bureau of Mines, Minneapolis, Minnesota, are acknowledged. In particular, Daryl Tweeton and Kent Peterson have offered advice on our laboratory and field work. 



\section{CONTENTS}

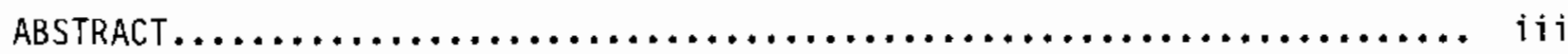

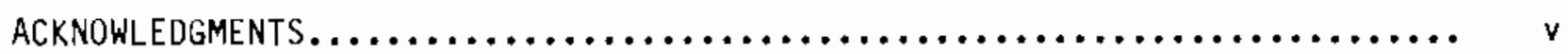

EXECUTIVE SUMMARY............................................. 1

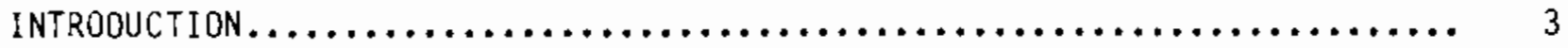

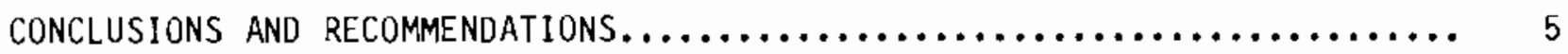

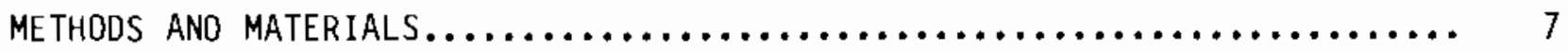

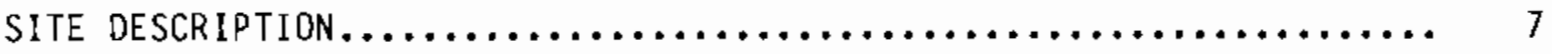

SAMPLING PROCEDURES $. \ldots \ldots \ldots \ldots \ldots \ldots \ldots \ldots \ldots \ldots \ldots \ldots \ldots \ldots \ldots, 10$

SAMPle Characterization.................................. 12

Mineralogy and Chemistry of Sediments..................... 12

Solution Analysis..................................... 13

SEOIMENT PREPARATION......................................... 16

BATCH EXPERIMENTS $\ldots \ldots \ldots \ldots \ldots \ldots \ldots \ldots \ldots \ldots \ldots \ldots \ldots \ldots \ldots \ldots \ldots, 17$

COLUMN EXPERIMENTS $. \ldots \ldots \ldots \ldots \ldots \ldots \ldots \ldots \ldots \ldots \ldots \ldots \ldots \ldots, 18$

Tracer Addition and Counting............................ 18

Experimental Design.................................., 20

GEOCHEMICAL MODELING $\ldots \ldots \ldots \ldots \ldots \ldots \ldots \ldots \ldots \ldots \ldots \ldots \ldots \ldots \ldots, 22$

RESULTS AND DISCUSSION................................... 27

LIXIVIANT AND GROUND WATER............................ 27

Solution Composition................................. 27

Excursion Detection Parameters......................... 31

Restoration Criteria.................................. 32

BATCH EXPERIMENTS $. \ldots \ldots \ldots \ldots \ldots \ldots \ldots \ldots \ldots \ldots \ldots \ldots \ldots \ldots \ldots \ldots \ldots \ldots \ldots, 32$ 
Response of Solution $\mathrm{pH}$, Eh, and Dissolved Oxygen Content

to Gas Purging and Sediment Interactions.................. 32

Solution Composition of the Batch Experiments............. 39

COLUMN EXPERIMENTS................................. 41

Series 1: Conducted with Equipment Exposed to Atmospheric

Oxygen and with Radiotraced Lixiviant as the Influent

Solution.

Series 2: Conducted in a Controlled Atmosphere (Argon)

Chamber with Untraced Lixiviant and Ground Water as the

Influent Solutions.................................... 44

Information on Chemical Processes from the Column Data........ 50

EXPERIMENTAL STUDIES APPLIED TD EXCURSION DETECTION AND AQUIFER

RESTORATION. ....................................... 55

EXCURSION DETECTION.............................. 55

NATURAL RESTORATION.............................. 58

REFERENCES........................................ Ref.1

APPENDIX A - COMPARISON OF CHEMICAL DATA AND RECOMMENDATIONS

FOR ANALYTICAL TECHNIQUES........................ A.I

APPENDIX B - COMPOSITION OF COLUMN EFFLUENTS................... B.1 


\section{FIGURES}

1 Location of Benavides In-Situ Leach Facility................ 8

2 Permitted Leach Fieids at Benavides and a Dip Section of the

Catahoula Formation................................... 9

3 Location of Sampling Wells at Benavides Site................ 11

$4 \quad X$-Ray Diffraction Patterns of Light (A) and Heavy (B) Mineral

Separations of Sediments............................... 14

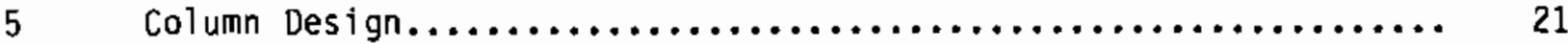

6 Schematic of Column Test Apparatus...................... 23

7 Schematic of Electrode Flow Cell ........................ 24

B Lixiviant Batch Tests $1 \mathrm{~A}$, 1B, and $1 \mathrm{C} \ldots \ldots \ldots \ldots \ldots \ldots \ldots \ldots \ldots \ldots$

$9 \quad$ Lixiviant/Reduced-Sediment Batch Tests $2 A, 2 B$, and $2 C \ldots \ldots \ldots \ldots$

$10 \quad$ Lixiviant/Leached-Ore Batch Tests $3 A$ and $3 B \ldots \ldots \ldots \ldots \ldots \ldots \ldots . \ldots . \ldots$

11 Distilled Water/Sediment Batch Tests $4 A, 4 B$, and $4 C \ldots \ldots \ldots \ldots . \ldots 38$

12 Concentration of Calcium and Sulfate in Effluents from

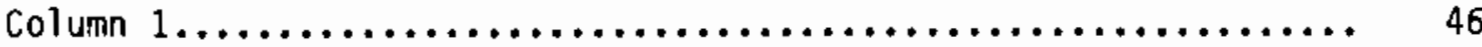

13 Concentration of Uranium in Effluents from Columns 2, 3 ,

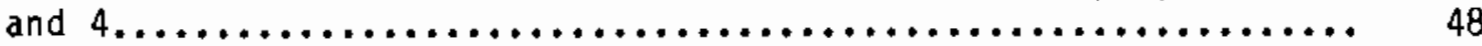

14 Effluent Eh Readings for Columns 2, 3, and $4 \ldots \ldots \ldots \ldots \ldots \ldots \ldots . \ldots 49$

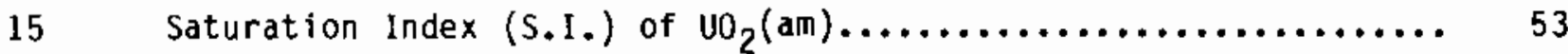

16 Distribution of Selenium Around a Roll-Front Uranium Deposit..... 60

17 Distribution of Arsenic Around a Roll-Front Uranium Deposit...... 61

18 Distribution of Molybdenum Around a Roll-Front Uranium Deposit... 62

\section{TABLES}

1 Chemical Analysis of Unmineralized Reduced-Zone Sediments from URI's Benavides Facility.............................. 13

2 Montmorillonite Element Analysis by XPS ................. 15 
3 Description of Stock Radiotracer Solutions................ 18

4 Comparison of Lixiviant Concentration of Metal with Amount of Tracer Added.......................................... 19

5 Concentration of Matrix Species Added by Tracer.............. 20

6 Details on Radiosiotope Counting...................... 20

7 Solution Characteristics of URI's Benavides Wells............ 28

8 Mean Concentration and Standard Deviation of Selected Constituents in the Ground Water and Lixiviant............... 30

9 Composition of Batch Solutions...................... 40

10 Radionuclide Content of Sediments After Lixiviant Flush......... 43

11 Percentage of Retained Nuclide that Travels Beyond Selected

Depths............................................

12 Mean Composition and Standard Deviation of Ground Water and

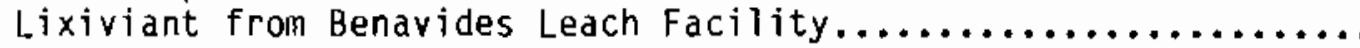

13 Ratios of Lixiviant and Selected Column Effluents to Ground-Water

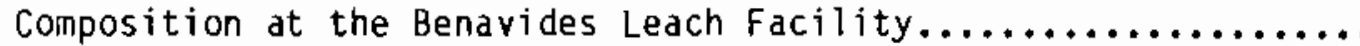

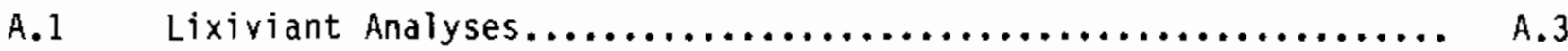

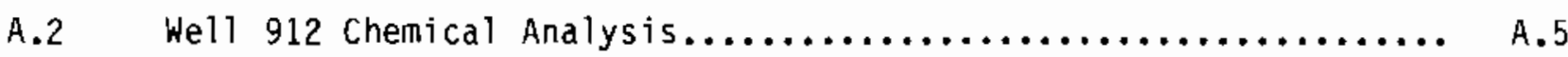

A.3 Recommended Analytical Techniques..................... A.7

B.1.1 Series 1 Column 1 Effluent Composition..................... B.2

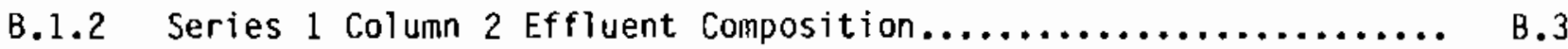

B.1.3 Series 1 Column 3 Effluent Composition................... B.4

B.1.4 Series 1 Column 4 Effluent Composition................... B.5

B.2.1 Series 2 Column 1 Effluent Composition..................... B.6

B.2.2 Series 2 Column 2 Effluent Composition................... B.7

B.2.3 Series 2 Column 3 Effluent Composition.................... B.9

B.2.4 Series 2 Column 4 Effluent Composition................... B.12 


\section{EXECUTIVE SUMMARY}

When uranium is mined by the in-situ leach method, a leaching solution (lixiviant) is injected into an aquifer containing the ore, and a uranium-rich solution (pregnant lixiviant) is recovered and processed at a local surface facility. Because the composition of the lixiviant differs from that of the original ground water in the aquifer, regulatory agencies require that the aquifer be restored when mining activities end, to prevent undesirable longterm changes in the chemical quality of the ground water. To restore the aquifer, its sediment and ground water must chemically re-equilibrate with the premining environmental condition of a deep, confined system. Natural restoration includes both the fast and slow reactions that occur in the aquifer as the water/sediment system moves toward equilibrium. Our laboratory experiments were designed to evaluate the effectiveness of natural restoration. This information can be used by NRC to set restoration criteria.

We used ground water, sediment, and lixiviant from an operating leach mine in southern Texas to simulate natural restoration in the laboratory. The composition of these materials provided baseline data on the site and was used for comparisons with experimental results. Our methods and equipment used for both the batch and flow-through column experiments were chosen to minimize contamination with oxygen in the atmosphere and to reflect actual deep aquifer conditions. The batch experiments provided short-term data on water/sediment interactions, whereas the column experiments allowed us to simulate lixiviant flow, through sediment representative of the aquifer, down the hydrologic gradient from a leached ore zone. We analyzed the solutions, as well as some of t\#e sediments, from the experiments.

The column experiments showed that the redox potential (Eh) and the concentrations of uranium and carbonate in the lixiviant are greatly affected by contact with a small amount of sediment. The Eh of the lixiviant changed from $+300 \mathrm{mv}$ to $-300 \mathrm{mv}$; the uranium concentration dropped from $52 \mathrm{ppm}$ to less than $5 \mathrm{pPm}$; and carbonate concentration decreased by half. The concentration of most of the major cations ( $\mathrm{Na}, \mathrm{Ca}, \mathrm{Mg}$, and $\mathrm{K}$ ) and anions ( $\mathrm{Cl}$ and $\mathrm{SO}_{4}$ ) in the column effluent was equal or close to that of the influent lixiviant. This suggests that these constituents of the lixiviant are not significantly retarded by chemical reactions as they pass through the column.

Our experiments showed that the dissolved oxygen level of the solution (either measured directly or inferred from the redox potential) is effectively lowered by water/sediment interactions. Uranium will precipitate in the columns because the redox condition changes; we expect a similar response from the redox-sensitive trace metals (e.g., As, Se, and Mo). The carbonate concentration changes in response to the precipitation of calcite. Carbonate minerals may scavenge trace metals from solution as they precipitate; this process would also lower the solution concentration of these metals. Because some of the dissolved constituents (e.g., $\mathrm{Cl}$ and SO4) of the lixiviant are not affected by flow through the columns, we believe that these constituents would be good indicators of the loss of control of lixiviant in the leach field. This loss of control of lixiviant and the lixiviant's movement into sediments 
surrounding the leach field is called an excursion. Excursions are detected by monitoring the composition of water in wells adjacent to the leach field. Our experiments have shown that the parameters that should be useful in identifying an excursion at a site include the total dissolved solids level and the solution concentrations of chloride and sulfate.

Our experiments are a first step in determining the effectiveness of natural restoration at a typical mine site. Our laboratory experinents indicate that natural restoration can reduce the concentration of at least some of the troublesome constituents $\left(\mathrm{CO}_{3}, \mathrm{U}, \mathrm{AS}\right.$, Se, and Mo) in the lixiviant. Field tests would verify these results and perhaps generate additional data on natural restoration processes. 
INTRODUCTION

Currently, about 14 pilot-scale operations and 26 commercial plants designed to mine uranium by the in-situ leach method are in various stages of development and production in Wyoming, Texas, New Mexico, and Colorado. This technique for recovering uranium involves the injection and removal of a leaching solution (lixiviant) from an aquifer containing the uranium ore zone. Because the lixiviant chemistry is significantly different from that of the original ground water, and because of the importance of preserving groundwater resources, various Federal and state agencies have set guidelines for restoring ground-water quality. Pacific Northwest Laboratory (PNL) conducted a series of laboratory experiments to investigate the potential for natural restoration of ground water in aquifers affected by in-situ leach mining of uranium. Natural restoration is defined as the natural capacity of an aquifer to restore itself by means of the normal physical and chemical processes that will occur in a water/rock system. This study was sponsored by the Nuclear Regulatory Commission (NRC) and is part of a research project to help the NRC formulate objective and defensible guidelines for in-situ mining regulations and restoration requirements. We plan additional research to complement this study on natural restoration to evaluate induced restoration techniques (e.g., ground-water sweeping, recirculation with chemical injection, and surface treatment).

Specifically, our laboratory experiments were designed to investigate the effects of natural chemical processes on restoration. Chemical reactions that would be expected to occur in the aquifer include oxidation-reduction, mineral precipitation and dissolution, ion complexation, and adsorption-desorption on solids. The theoretical influence of these processes on aquifer restoration is described in Riding and Rosswog (1979). Our experiments were designed to simulate lixiviant as it flows out of the ore zone and interacts with the sediments downgradient of the leached area and to determine the actual response of the solution composition to solution/sediment interactions.

This report describes types of solution and sediments used in the tests, the techniques used to evaluate natural restoration, and the results of the experiments. Possible solution parameters that are identified in this study to detect the excursion of lixiviant are also discussed. 



\section{CONCLUSIONS AND RECOMMENDATIONS}

The laboratory experiments in this report and on which the following conclusions are based consisted of 11 short-term (1-and 2-day) batch experiments and 2 series of flow-through column tests of two weeks and four weeks duration. The ground water, sediment, and leaching solutions (lixiviants) used in the experiments came from a single uranium leach facility in southern Texas. Geologic and geochemical conditions at this site can be considered representative of conditions throughout the extensive Texas Gulf Coast mining district. Although the results of our experiments strictly apply only to this region, the chemical processes identified as active in these aquifers should be representative of deep, confined aquifers in most places where uranium rollfront deposits occur. Our experiments show that:

- Batch tests and, particularly, flow-through column experiments adequately simulate the geochemical environment at depth in an orezone aquifer. These experiments can determine some of the important chemical reactions that will occur between lixiviant and aquifer sediment.

- The concentration of uranium in solution, and by inference the concentration of other redox-sensitive contaminants, will be lowered as secondary minerals and amorphous solids are formed.

- The concentration of major cations ( $\mathrm{Na}, \mathrm{Ca}, \mathrm{Mg}$, and $\mathrm{K}$ ) in solution may be changed by jon exchange, but their concentration in solution will not be limited by the formation of a solid phase, nor will the total dissolved solids level of the leaching solution be appreciably changed by interactions with the sediments.

- The fate of major anions in solution varies by constituent. Chioride concentrations are not expected to be affected by chemical processes in the aquifer. Carbonate concentration appears to be limited by the formation of carbonate minerals, especially calcite. The concentration of dissolved sulfate was not affected by solution/sediment interactions occurring in our experiments.

- Based on the changes in solution composition noted in the flowthrough tests and on the typical concentration of ground water surrounding the uranium ore zone, the chloride and sulfate concentration and total dissolved solids level of water in monitoring wells would be good indicators of excursions of the lixiviant from the leach field.

The results of the laboratory experiments must be verified by field studies; however, we can tentatively recommend that natural processes be included as an important mechanism of aquifer restoration when restoration criterid are established for certain ground-water constituents. Completed experiments show that the list of dissolved constituents affected by natural restoration processes includes uranium and carbonate, and possibly redoxsensitive trace metals (e.g., As, Se, and Mo). 


\section{-}




\section{METHODS AND MATERIALS}

This section contains information on the mining facility where we collected samples of aquifer sediments, ground water and lixiviant, and explains the methods we used to collect and characterize the solutions and sediment. We discuss the experimental methods as well as the use of geochemical models to analyze the data.

\section{SITE DESCRIPTION}

The Gulf Coast of Texas is one of the primary in-situ uranium mining districts in the U.S. Uranium ore is present in roll-front deposits located in a number of sedimentary aquifers. The Catahoula aquifer system in the southern portion of the Texas Coastal Plain contains a number of economically important roll-front deposits. The origin and subsequent geochemical evolution of the Catahoula have been discussed by Galloway (1977) and Galloway and Kaiser (1980), with emphasis on uranium mineralization. They have reconstructed the probable sequence of events leading to the current roll-front deposits as follows:

1. Weathering in the soil zone released uranium from tuffaceous deposits and mobilized it as a uranyl bicarbonate complex.

2. The uranium-rich ground water was reduced by reaction with pyrite and organic matter.

3. Uranium was concentrated in part by adsorption onto montmorillonite, amorphous $\mathrm{TiO}_{2}$, and/or organic material.

4. Following adsorption, U(VI) was reduced to U(IV) and amorphous uranous oxides and silicates were formed. The association of the uranium compounds with iron oxidation products at the redox interface results in the distinctive roll-front deposit (Granger and Warren 1974).

Many of these deposits are currently mined by the in-situ leach technique, which is an economical alternative to conventional mining methods when the ore is relatively deep and of low grade.

We collected samples of ground water, lixiviant, and uncontaminated aquifer sediments for the initial experimental studies on aquifer restoration from the Benavides in-situ uranium leach facility near Bruni, Texas (Figure 1), operated by Uranium Resources, Inc. (URI). URI has been leaching ore at the Benavides Site since February, 1980. Figure 2 shows the current permitted leach fields and also shows a dip section displaying the local stratigraphy of the Catahoula Formation. The $A, B$, and $C$ sands are production zones at this site. Wells in the D and $E$ sands are used for monitoring. A 60 foot thick impermeable tuffaceous clay layer underlies the A sand, effectively confining production fluid above it. 


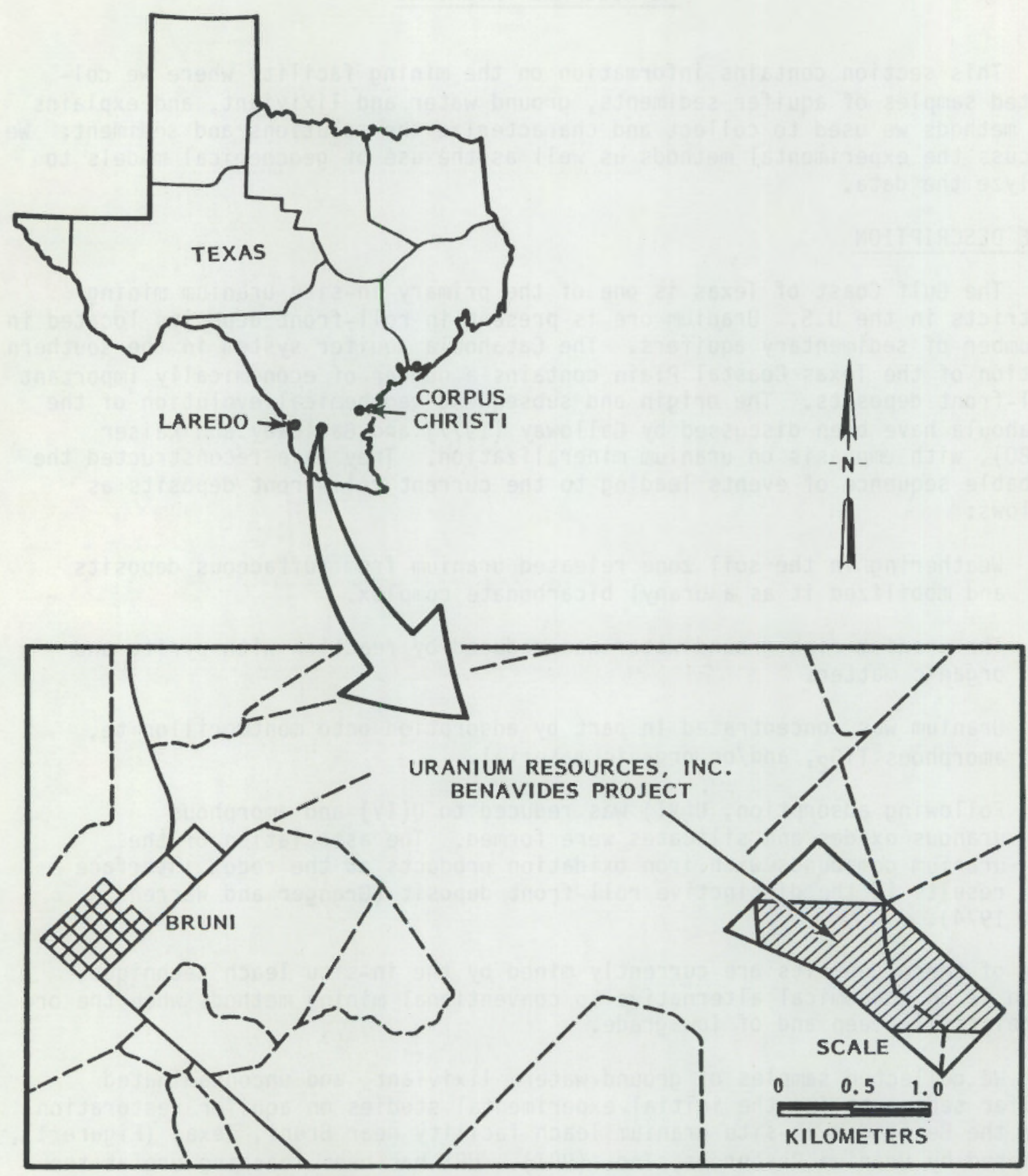

FIGURE 1. Location of Benavides In-Situ Leach Facility 


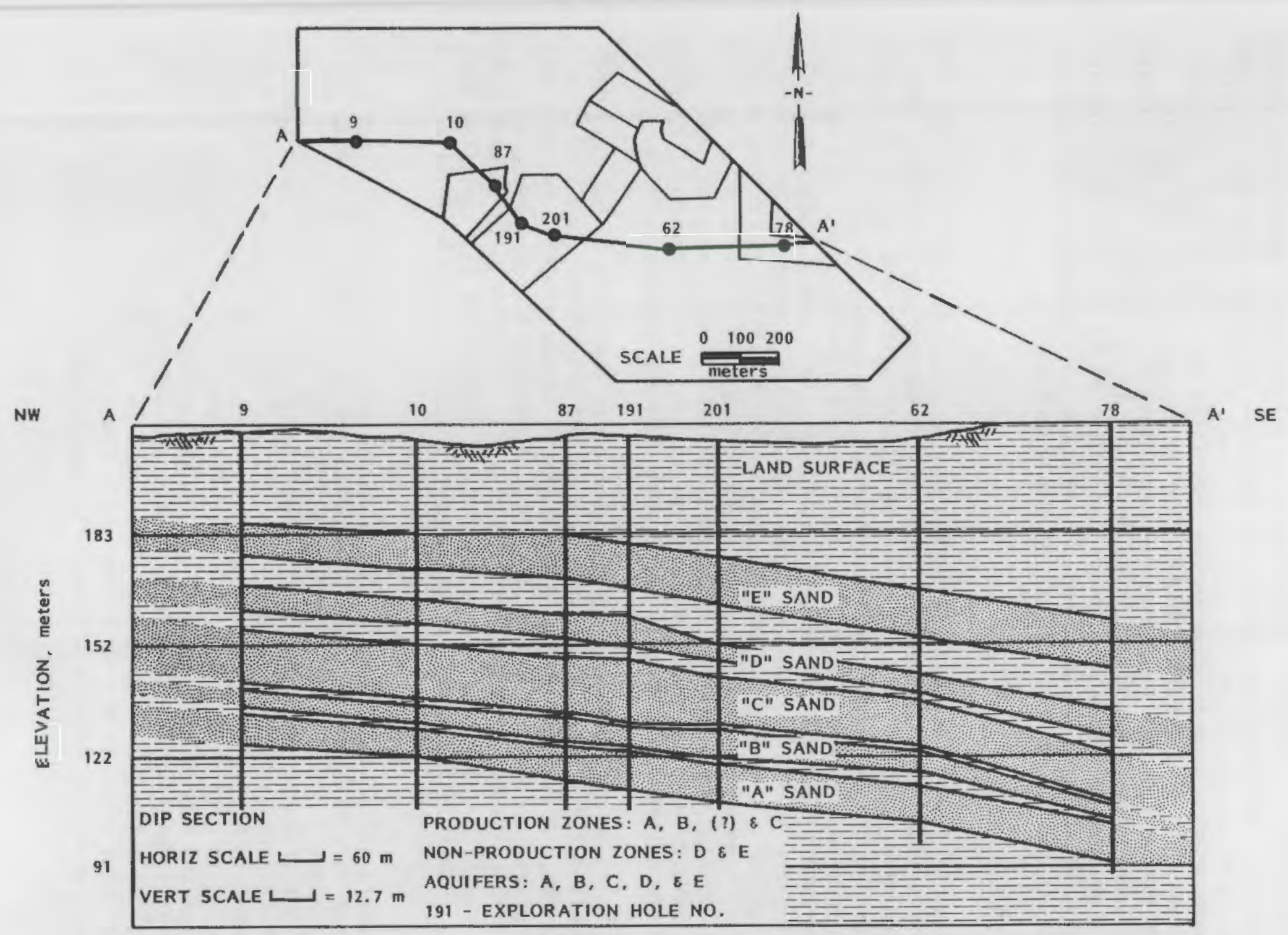

FIGURE 2. Permitted Leach Fields at Benavides and a Dip Section of the Catahoula Formation (After URI Staff 1979. Application and Technical Report: Benavides In Situ Uranium Leach Project. Uranium Resources, Inc., Richardson, Texas). 
The Benavides plant uses a leach solution consisting of $\mathrm{Na}-\mathrm{HCO}_{3}-\mathrm{Cl}$ ground water that has been fortified through the addition of carbon dioxide and oxygen gas. The lixiviant is pumped into the roll-front formation where it oxidizes and releases uranium from U(IV) minerals (uraninite and coffinite). The uranium combines with dissolved carbonate, forming mobile neutral and anionic $U(V I)$ complexes. The resulting uranium-rich solution is pumped to the surface where the uranium is stripped out. The lixiviant is refortified and reinjected. When uranium production from a particular field falls below a profitable level, the affected aquifers must be restored to a predetermined chemical quality based on the original quality of the ground water.

\section{SAMPLING PROCEDURES}

Samples of ground water and lixiviant were collected at the Benavides site during March, 1982, for analysis and use in the laboratory experiments. We took ground-water samples from the ore-zone aquifer within the ore zone itself and up and down the hydrologic gradient from the ore zone. Ground water was also sampled from the 0 sand aquifier above the ore-zone aquifer. All water samples were retrieved with submersible stainless steel pumps installed in fiberglass-cased wells. Galvanized piping connected the pump to the surface sampling equipment. Before collecting samples for analysis, the ground-water sampling wells were pumped until temperature, $\mathrm{pH}$, and Eh stabilized. Figure 3 shows the location of all the wells sampled for this study. We obtained lixiviant samples with high (54 ppm) and low (3 ppm) uranium content from wells in one of the active leach fields; these wells did not require purging.

Samples to be analyzed later were preserved in the field through acidification, cooling, or freezing according to accepted procedures (EPA 1979) and shipped to PNL. A suite of unstable ground-water parameters that included $\mathrm{pH}$, Eh, temperature, conductivity, and dissolved oxygen content were measured onsite. Alkalinity was determined in the field by titration with standardized acid, and ammonium and sulfide concentrations were measured with specific ion electrodes. The complete chemical analyses are discussed in the Results and Discussion Section on lixiviant and ground water.

To obtain sediment samples for batch and column laboratory experiments, we drilled four coreholes and recovered approximately $18 \mathrm{~m}$ (59 ft) of $7.6-\mathrm{cm}$ (3-in.) diameter core. The material represents samples of leached and unleached ore, reduced sediments downgradient from the roll front, and sediments from the aquifer above the ore zone. We photographed and described the core material in the field, then wrapped each $50-\mathrm{cm}$ length of core in plastic and placed it in a tight-fitting PVC tube. The core material displaced most of the air from the tube, which was then capped and sealed with a silicone rubber sealant. This description and preservation procedure took 30 minutes to 1 hour for each three-meter core recovered. This packaging procedure appears to have effectively kept the sample from drying out. However, as will be discussed later, some air was apparently trapped with the sediment in the container; this oxidized some of the minerals. 


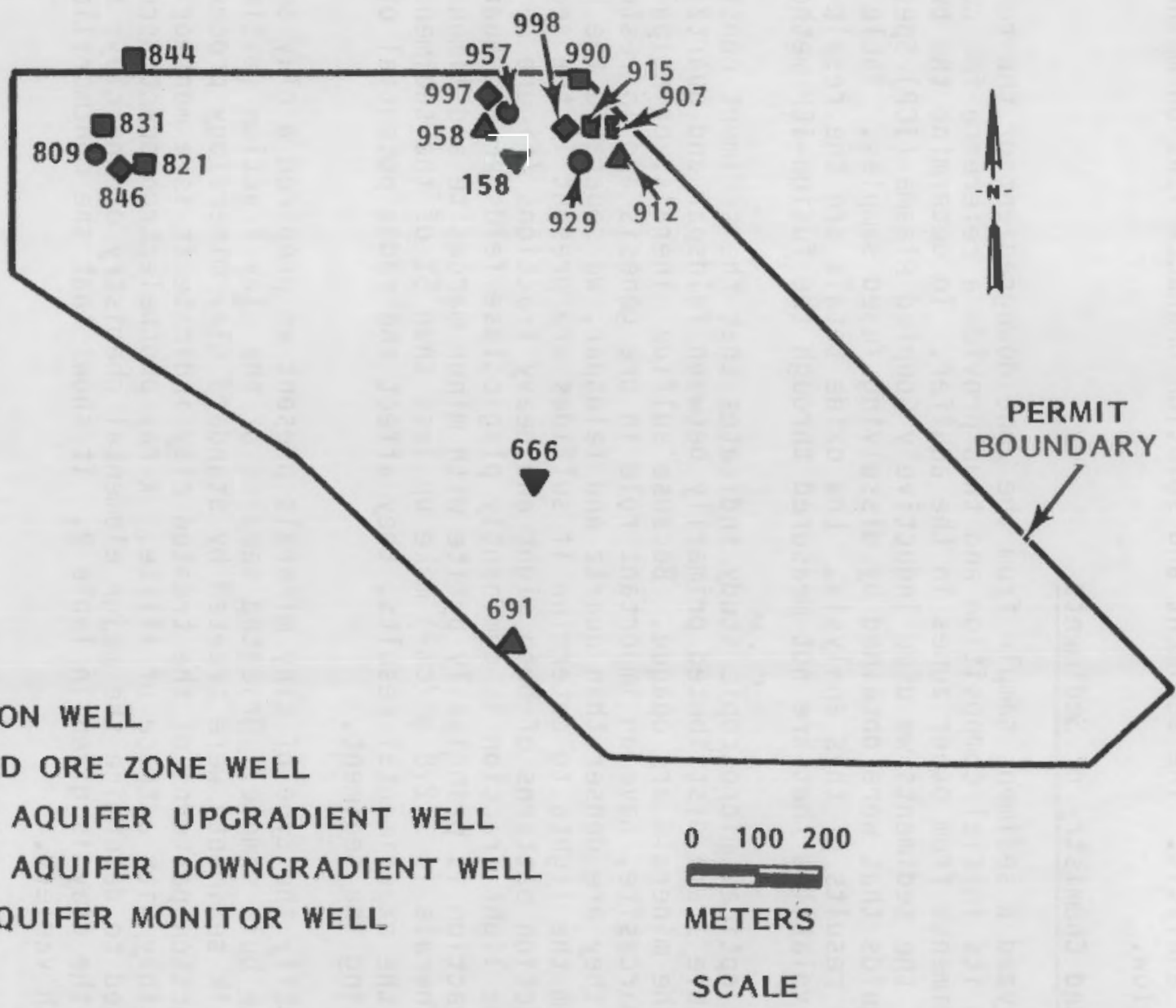

FIGURE 3. Location of Sampling Wells at Benavides Site 


\section{SAMPLE CHARACTERIZATION}

The solution and sediment samples obtained from the Benavides in-situ mine were shipped to PNL for experimental studies of restoration and for physical and chemical analysis. The sediment and solution characterization methods are discussed below.

Mineralogy and Chemistry of Sediments

We analyzed a sediment sample from the zone downgradient of the roll front to establish its initial composition and thus provide a reference for comparison with sediments from other zones in the aquifer. To determine the bulk chemistry of the sediments we used Inductively Coupled Plasma (ICP) Spectroscopy on liquids that were obtained by dissolving fused samples. Table 1 presents the results of this analysis. Low oxide totals are the result of the presence of volatiles that are not measured through the fusion-ICP method.

Routine optical microscopic study indicates that the sediment constituents listed in Table 1 are distributed primarily between feldspar and quartz; less than $5 \%$ of the minerals are opaque. Because sulfide minerals, principally pyrite and marcasite, have an important role in ore genesis and in restoration, and because they are denser than quartz and feldspar, we separated the heavy minerals from the lights to determine if sulfides are present in the sediment. $X$-ray diffraction patterns of both light and heavy fractions (Figure 4) indicate that the light fraction is dominantly plagioclase feldspar and quartz and the heavy fraction is principally pyrite with minor marcasite and ilmenite. The heavy minerals ( $\rho>2.8 \mathrm{gm} / \mathrm{cm}^{3}$ ) make up less than $5 \%$ of the sediment but, as shown by the experimental results, they affect the redox potential of solution contacting the sediment.

To identify the type of clay minerals present we prepared a clay separation from the bulk sample. Oriented samples of the clay fraction (estimated at $5 \%$ of the bulk sediment) were treated by standard clay mineralogy procedures. $X$-ray diffraction patterns of the treated clay indicate it is a montmorillonite, possibly with a trace of illite. X-ray photoelectron spectroscopy (XPS) was used to determine the major elemental chemistry of the clay; the XPS analysis of the clay is given in Table 2. It shows that the montmorilionite is a sodium-rich variety.

The XPS technique is useful for studying the surface chemistry of materials including the oxidation state of elements on or near the surface. Used with ion milling procedures, this technique provides elemental depth profiles. Although the capability of determining element oxidation states on solid surfaces has most frequently been applied to simple systems, for example, to test the corrosion of metals, several studies concern sorption of metals on clays (e.g., Koppelman and Dillard 1980). In addition, recent work on Fe oxidation states in iron oxides (McIntyre and Zetaruk 1977) indicates that these techniques may be extended to other minerals, potentially to examine the redox effects of both lixiviants and restoration processes on minerals associated with uranium ore deposits. Additional work is planned for U-bearing samples to 
TABLE 1. Chemical Analysis of Unmineralized Reduced-Zone
Sediments from URI's Benavides Facility(a)

\begin{tabular}{|c|c|}
\hline Element & Weight, \% \\
\hline $\mathrm{SiO}_{2}$ & 62.7 \\
\hline $\mathrm{Al}_{2} \mathrm{O}_{3}$ & 9.7 \\
\hline $\mathrm{Nà}_{2}{ }^{O}$ & 2.4 \\
\hline $\mathrm{K}_{2} \mathrm{O}$ & 1.5 \\
\hline $\mathrm{CaO}$ & 7.1 \\
\hline $\mathrm{MgO}$ & 0.5 \\
\hline Sro & 0.04 \\
\hline $\mathrm{Ba} 0$ & 0.1 \\
\hline $\mathrm{Fe}_{2} \mathrm{O}_{3}$ & 2.3 \\
\hline TiO & 0.4 \\
\hline Zro & 0.02 \\
\hline$\underline{S O}_{4}{ }^{(b)}$ & 1.7 \\
\hline Total & 88.5 \\
\hline $\mathrm{Cu}(\mathrm{ppm})$ & 19 \\
\hline $\mathrm{Zn}(\mathrm{ppm})$ & 15 \\
\hline
\end{tabular}

(a) Analysis excludes $\mathrm{H}_{2} \mathrm{O}, \mathrm{CO}_{2}, \mathrm{~S}$, Organics.

(b) Probably obtained from pyrite during fusion.

determine $U$ oxidation states. Related to this, we will analyze U-bearing samples by scanning electron microscopy and microprobe analysis to determine if $U$ is present as a discrete phase or as a surface coating.

\section{Solution Analysis}

We determined the concentration of dissolved metals in the ground water, lixiviant, and laboratory solution on samples acidified with nitric acid to a $\mathrm{pH}$ less than 2. Both ICP spectrometry and graphite-furnace atomic absorption spectroscopy (GFAA) were used. The high uranium content of the lixiviant and column effluents caused numerous spectral interferences with other elements when we used the ICP technique. Where appropriate, the uranium interference signal (based on signals obtained from $U$ standards) was subtracted from the observed signal to estimate the actual analyte concentration. For several elements ICP analyses were not sensitive enough or exhibited nonlinearity upon 


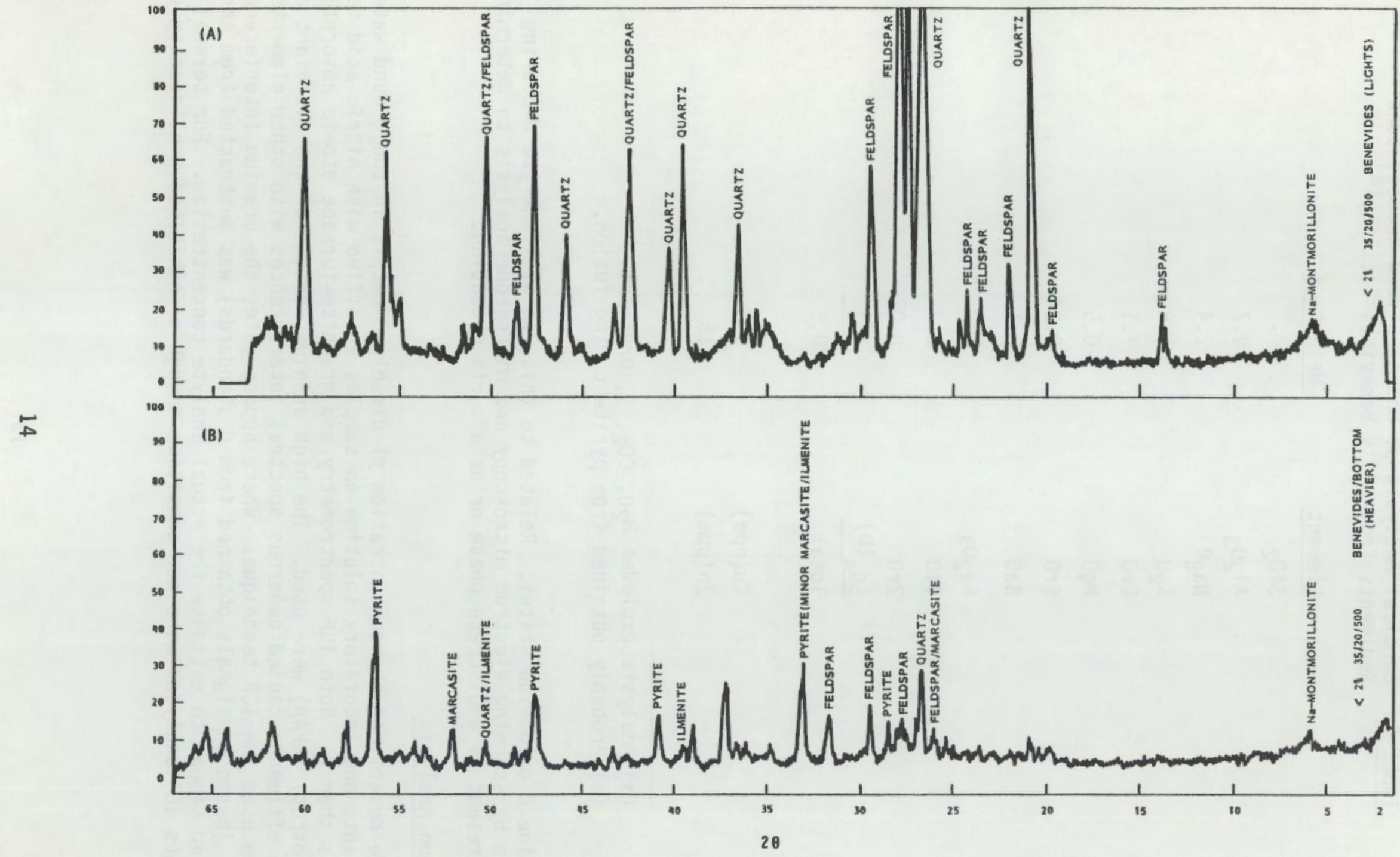

FIGURE 4. X-Ray Diffraction Patterns of Light (A) and Heavy (B) Mineral Separations of Sediments 
TABLE 2. Mortinorillonite Element Analysis by XPS

\begin{tabular}{lc} 
Element & Atomic Percent \\
\cline { 2 - 2 } $\mathrm{O}$ & 63.9 \\
$\mathrm{Cl}^{(\mathrm{a})}$ & 4.4 \\
$\mathrm{Fe}$ & 0.2 \\
$\mathrm{Ca}$ & 0.4 \\
$\mathrm{Si}$ & 20.2 \\
$\mathrm{Al}$ & 8.8 \\
$\mathrm{Na}$ & 1.5 \\
$\mathrm{~K}$ & 0.6
\end{tabular}

(a) Background $\mathrm{C}$ is normally present and is not necessarily in the clay.

dilution. Several of these elements ( $\mathrm{Al}, \mathrm{V}, \mathrm{Cr}, \mathrm{Mn}, \mathrm{Fe}, \mathrm{Cu}, \mathrm{As}$, and $\mathrm{Pb}$ ) were measured by the atomic absorption technique. Acidified samples were analyzed by GFAA, using dilution and known addition techniques to minimize and to evaluate matrix effects. In most instances dilution minimized matrix effects and so recoveries of known additions were similar to the recoveries obtained in distilled water.

Uranium was analyzed by pulsed laser fluorimetry. We mixed aliquots of the acidified samples with a solution containing a complexing agent and measured the long-lived fluorescence of the $U$ complex. Then, a knowh addition of uranium was added and the fluoresence remeasured. This known addition result was used to correct for any matrix effects. The fluorimetric measurement is extremely sensitive ( 50 parts per trillion is the detection limit for a $1 \mathrm{ml}$ water sample); thus, for the lixiviant samples, large dilutions were possible and matrix effects were minimal.

We measured the anion content of the ground waters, lixiviants, and column effluents by ion chromatography on untreated samples. The procedure is to chromatographically separate the anions on a column and then detect the peaks via conductivity measurements as the anions elute from the column. A carrier solution $\left(0.028 \mathrm{M} \mathrm{Na}_{2} \mathrm{CO}_{3}-0.003 \mathrm{M} \mathrm{NaHCO}_{3}\right)$ elutes the anions and maintains a known background conductivity level. The anions are identified through standard curves in the same carrier solution. The time of peak elution is essentially unique for each anion and the change in conductivity is directly proportional to the concentration of the anion. Because the carrier eluant is a carbonate-bicarbonate solution, these anions must be analyzed separately. We chose a classical standard acid titration procedure (ASTM D-1067, Part 31) but used an automatic titrator. Instead of titrating to a fixed endpoint $\mathrm{pH}$, we determined the alkalinity by measuring the milliequivalents of acid used to reach an inflection point in the $\mathrm{pH}$ curve. 
The $\mathrm{pH}$, Eh, and conductivity of the ground water and lixiviants were measured in the field using in-line sensors connected to the pump line. We used sensors consisting of a combination glass electrode, platinum electrode, and conductivity cell.

Two sets of column and batch experiments were run to investigate natural restoration. During the August 1982 experiments the $\mathrm{pH}$ and Eh of column effluents and batch slurries were measured with standard electrodes within a period of an hour to one day after collection. During the November-December 1982 tests the experiments were conducted in contrọlled-atmosphere (argon) chambers to reduce the influence of atmospheric oxygen on the redox potential. In the latter tests, in-line $\mathrm{pH}$ - and Eh-measuring cells were used on the column apparatus to get accurate measurements and a salt bridge was used for the batch slurry measurements to eliminate 'streaming potential'. The in-line systems allowed continuous monitoring of $\mathrm{pH}$ and Eh. The in-line sensors are described in more detail in the section on column experimental design.

For the ground-water and lixiviant samples we attempted to determine the valence state distribution of iron [Fe(II)/Fe(III)] and arsenic [As(III)/As(V)]. During field collection special samples were preserved by acidification with hydrochloric acid for $\mathrm{Fe}$ analyses and by rapid freezing for As analyses. We used the bathophenanthroline procedure (Lee and Stumm 1960; Ghosh, $0^{\prime}$ Connor and Engelbrecht 1967) to measure the solution concentration of the iron oxidation states. With this procedure, the Fe(II) content of a subsample is measured spectrophotometrically following complexation with bathophenanthroline. A second subsample is treated with hydroxylamine hydrochloride (a reducing agent) to convert all the iron to $\mathrm{Fe}$ (II), and total iron is determined. The $\mathrm{Fe}$ (III) concentration is the difference of the two analytical values. The arsenic valence states were determined using a helium d.c. plasma emission source and a monochrometer and phototube detector set at an arsenic emission line. The solution sample is reduced with sodium borohydride at a $\mathrm{pH}$ above 3 to convert As(III) to arsine gas. The arsine gas is preconcentrated in a liquid nitrogen cold trap. After the arsine is collected it is rapidly heated and driven into the d.c. plasma for analysis. Potential interferences of $\mathrm{CO}_{2}(\mathrm{~g})$ and $\mathrm{H}_{2} \mathrm{~S}(\mathrm{~g})$ are removed by placing a strong $\mathrm{NaOH}$ caustic trap between the cold trap and the d.c. plasma. Either the same aliquot of sample or a second aliquot is then made more acidic $(\mathrm{pH}<2)$ and further reduced. Below a $\mathrm{pH}$ of 2 both As(III) and As(V) form arsine gas. Thus, As(V) can be measured directly on the same sample used for analysis of As(III) or total As can be determined on a separate sample and $A s(V)$ can be determined by difference. Forbeck (1973) and Crecelius (1978) gives details on this As-measurement technique.

\section{SEDIMENT PREPARATION}

In most of the batch tests and in the column tests we used sediment recovered from the ore-zone aquifer downgradient from the uranium deposit. (The sediment represented reducing aquifer conditions, as evidenced by the presence of pyrite and marcasite.) The sediment container was opened in a plastic glove bag purged of atmospheric oxygen with nitrogen ( $99.5 \%$ pure). 
After the sediment was homogenized, samples were taken and the sediment was stored in a 5-gal plastic paint bucket with an 0-ring seal in the nitrogen glove bag. After samples were removed, the glove bag was repurged with nitrogen. When additional samples were taken, the same precautions were followed: the glove bag was purged with nitrogen after each time it was opened, and the sample containers were only opened in a nitrogen atmosphere. Three months after the first samples were taken, the sediment was still damp and unchanged in color and water had collected on the bucket lid--indicating a good seal. However, as will be seen by the effluent $\mathrm{SO}_{4}$ concentrations from the column tests, some of the pyrite did oxidize between the time when the samples were collected at the site and when the tests were run. As mentioned, this oxidation probably was initiated at the site when the sediment was briefly exposed to the atmosphere during recovery.

\section{BATCH EXPERIMENTS}

Batch experiments provided qualitative data in a short period of time on the chemical reactions between lixiviant and sediments from the reduced zone of the aquifer, and between lixiviant and leached ore. Baseline characterization tests of lixiviant without sediment show how the lowering of oxygen and carbon dioxide gas levels in solution affects the Eh and $\mathrm{pH}$ of the solution. These solution parameters were measured for lixiviant: 1) open to the atmosphere (Test 1A), 2) purged with nitrogen and held in a glove bag (Test 1B), and 3) purged of gases with argon held in a controlled atmosphere (argon) chamber (Test 1C).

The combination of lixiviant with reduced sediments (Tests $2 \mathrm{~A}, 2 \mathrm{~B}$, and $2 \mathrm{C}$ ) provides an estimate of the natural restorative ability of the sediments downgradient from the ore zone. Results are qualitative because the solution to solid ratio necessary to conduct the batch experiments (typically $4: 1$ by volume) are not representative of aquifer conditions; however, the short-term (less than a week) experiments indicate conditions to expect in the column experiments. We ran lixiviant and leached ore tests ( $3 A$ and $3 B$ ) to evaluate the residual reducing capacity of ore that had been leached under actual mining conditions.

Distilled water was mixed with leached ore (Tests $4 A$ and $4 C$ ) and with reduced sediments (Test $4 \mathrm{~B}$ ) to evaluate the reducing capacity of the solids with respect to a poorly poised (Eh-buffered) solution (distilled water) and a solution with some redox-sensitive constituents (lixiviant). In addition, the composition of the resulting mixture of distilled water and partially saturated sediments provides an estimate of the composition of the original pore water in the sediments.

During all tests, we measured the $\mathrm{Eh}, \mathrm{pH}$, and dissolved oxygen level either at close intervals or continuously by means of a strip-chart recorder. We determined the Eh with a combination platinum/reference electrode connected to a multifunction $\mathrm{pH} / \mathrm{mv} /$ temperature meter. The measuring system was calibrated daily with quinhydrone added to $\mathrm{pH} 4$ and $\mathrm{pH} 7$ buffer solutions. A combination glass electrode and $\mathrm{pH}$ meter was used to monitor changes in $\mathrm{pH}$. 
This electrode was also calibrated daily with buffer solutions. Initially, dissolved oxygen was measured with a dissolved oxygen meter equipped with a clark-type probe. The sensitivity of this instrument at low oxygen levels (<1 ppm) was not satisfactory; consequently, we used the Winkler titration method with a detection limit of $0.1 \mathrm{ppm}$ for most tests. The solution composition was determined at regular intervals during Tests $1 \mathrm{C}, 2 \mathrm{C}, 3 \mathrm{~B}, 4 \mathrm{~B}$, and $4 C$. Analytical methods are described in the previous section on solution analysis.

\section{COLUMN EXPERIMENTS}

The apparatus used in the two series of column experiments was essentially the same; however, the procedures differed somewhat. In the August 1982 test, we used radioactive tracers in an attempt to monitor the progress of trace constituents through the columns; we did not attempt to eliminate contact of the pump, columns, or connecting lines with the atmosphere. During the NovemberDecember 1982 column tests, we did not use tracers because the tracer data obtained from the earlier test were not completely reliable and because of the added complications of handling radioactive tracer solutions. In addition, the second test was run in a controlled-atmosphere (argon) chamber to reduce the possibility of oxygen contamination. The experimental procedures are described in detail in the following sections.

Tracer Addition and Counting

For the August 1982 column tests the lixiviant with $54 \mathrm{ppm} U$ was filtered through $0.22-\mu \mathrm{m}$ membranes and the following radionuclides were added to four subsamples, The solutions labeleg 1 through 4 contained the tracers ${ }^{73}$ As, ${ }^{109} \mathrm{Cd}$ and ${ }^{210} \mathrm{~Pb}$; ${ }^{51} \mathrm{Cr}$ and ${ }^{75} \mathrm{Se}$; ${ }^{54} \mathrm{Mn}$ and ${ }^{59} \mathrm{Fe}$; and ${ }^{228} \mathrm{Ra}$, respectively. The radiotracers were high specific-activity solutions in the matrices, listed in Table 3. The tracers were added to the lixiviant in the proportions shown in Table 4 ; based on specific-activity values, the amount of added stable carrier was calculated.

TABLE 3. Description of Stock Radiotracer Solutions

\begin{tabular}{|c|c|c|c|c|}
\hline Tracer & Form & Matrix & $\begin{array}{c}\text { Stock } \\
\text { Activity, mci/ml } \\
\end{array}$ & $\begin{array}{c}\text { Specific } \\
\text { Activity, mci/mg }\end{array}$ \\
\hline${ }^{51} \mathrm{Cr}$ & $\mathrm{Na}_{2} \mathrm{CrO}_{4}$ & $0.08 \mathrm{M} \mathrm{NaCl}$ & 0.03 & $3.5 \times 10^{2}$ \\
\hline${ }^{54} \mathrm{Mn}$ & $\mathrm{MnCl}_{2}$ & $0.09 \mathrm{M} \mathrm{HCl}$ & 10.0 & $8.0 \times 10^{3}$ \\
\hline${ }^{59} \mathrm{Fe}$ & $\mathrm{FeCl}_{3}$ & $0.09 \mathrm{M} \mathrm{HCl}$ & 0.04 & 3.0 \\
\hline $73_{\text {As }}$ & $\mathrm{H}_{3} \mathrm{AsO}_{4}$ & $0.065 \mathrm{M} \mathrm{HCl}$ & 0.06 & $2.2 \times 10^{4}$ \\
\hline${ }^{75} \mathrm{Se}$ & $\mathrm{H}_{2} \mathrm{SeO}_{3}$ & $0.12 \mathrm{M} \mathrm{HNO} 3$ & 0.31 & 2.0 \\
\hline${ }^{109} \mathrm{Cd}$ & $\mathrm{CdCl}_{2}$ & $0.09 \mathrm{M} \mathrm{HCl}$ & 0.07 & $2.6 \times 10^{3}$ \\
\hline $210 \mathrm{pb}$ & $\mathrm{Pb}\left(\mathrm{NO}_{3}\right)_{2}$ & $3.0 \mathrm{OM} \mathrm{HNO} 3$ & 0.2 & $2.0 \times 10^{1}$ \\
\hline${ }^{228} \mathrm{Ra}$ & $\mathrm{RaCl}_{2}$ & $0.1 \mathrm{M} \mathrm{HCl}$ & 0.001 & not known \\
\hline
\end{tabular}


TABLE 4. Comparison of Lixiviant Concentration of Metal with Amount of Tracer Added

\begin{tabular}{|c|c|c|c|}
\hline Iracer & $\begin{array}{c}\text { Avount } \\
\text { of Tracer } \\
\text { Added, } \mathrm{ml} / \ell \\
\end{array}$ & $\begin{array}{l}\text { Stable } \\
\text { Carrier } \\
\text { Added, ppm } \\
\end{array}$ & $\begin{array}{l}\text { Lixiviant } \\
\text { Concentration, ppm } \\
\end{array}$ \\
\hline${ }^{51} \mathrm{Cr}$ & 0.0125 & $1 \times 10^{-6}$ & $<2 \times 10^{-2}$ \\
\hline $54_{M n}$ & 0.005 & $6 \times 10^{-6}$ & $4 \times 10^{-1}$ \\
\hline${ }^{59} \mathrm{Fe}$ & 0.350 & $5 \times 10^{-3}$ & $8 \times 10^{-2}$ \\
\hline $73 \mathrm{As}$ & 0.60 & $2 \times 10^{-7}$ & $<5 \times 10^{-2}$ \\
\hline${ }^{75} \mathrm{Se}$ & 0.085 & $1 \times 10-2$ & $2 \times 10^{-2}$ \\
\hline${ }^{109} \mathrm{Cd}$ & 0.085 & $2 \times 10^{-6}$ & $4 \times 10^{-3}$ \\
\hline $210_{\mathrm{Pb}}$ & 0.050 & $5 \times 10^{-4}$ & $<1 \times 10^{-2}$ \\
\hline${ }^{228} \mathrm{Ra}$ & 0.424 & unknown & unknown \\
\hline
\end{tabular}

The acid matrix of the tracers added the constituents shown in Table 5 . The final pH of the traced lixiviants is very similar to the $\mathrm{pH}$ of the original solution despite the addition of between $10^{-4}$ and $10^{-5}$ moles/liter of acid. The large bicarbonate concentration $\left(1.04 \times 10^{-2} \mathrm{M}\right)$ of the lixiviant buffers the solution. Solutions \#1 and \#2 (see Table 5) add measurable and significant amounts of nitrate to the lixiviant. The amount of sodium and chloride added is insignificant compared to the original concentrations in the lixiviant.

The radionuclide contents of column effluents were compared to activities measured on the original-traced solutions \#1 through \#4. Fourteen milliliters of solution were placed in a $20 \mathrm{ml}$ polyethylene liquid scintillation vial. One milliliter of dilute nitric acid was added to reduce the $\mathrm{pH}$ to about 2. This acidification prevented tracer precipitation within the counting vials. The count rates of the radioisotopes in these liquid samples of fixed $15-\mathrm{ml}$ geometry were measured on the detectors listed in Table 6 .

When the August 1982 flow-through column tests were completed, we dissected and analyzed the sediment cores for the presence of natural radioactive elements and of the radiotracers added to the influent solutions. Each of the four cores was split into the following six segments (measured from the influent end of the column): 0 to $2.5 \mathrm{~cm}, 2.5$ to $3.8 \mathrm{~cm}, 3.8$ to $5.1 \mathrm{~cm}, 5.1$ to $14.0 \mathrm{~cm}, 14.0$ to $20.3 \mathrm{~cm}, 20.3$ to $25.4 \mathrm{~cm}$. For the radiotracers $51 \mathrm{Cr}, 54 \mathrm{Mn}$, ${ }^{59} \mathrm{Fe},{ }^{7} \mathrm{As}, 75 \mathrm{Se},{ }^{109} \mathrm{~cd}, 210 \mathrm{~Pb}$, and uranium and its daughter products, $15 \mathrm{~g}$ of dry sediment were mixed with cellulose binder and pressed into a thin disk of standard geometry. The thin disks were covered with plastic wrap, placed in a holder, and counted on the appropriate detector. For the radium-228 traced sediments, $20 \mathrm{~g}$ of dry sedment were placed in a $25-\mathrm{ml}$ polyethylene vial and were then counted with the 5-inch $\mathrm{NaI} \gamma$ detector. 
TABLE 5. Concentration of Matrix Species Added by Tracer

\begin{tabular}{|c|c|c|c|c|c|}
\hline Solution & $\mathrm{H}, \mathrm{m}$ & Cl, ppm & $\mathrm{Na}, \mathrm{ppm}$ & $\mathrm{NO}_{3}, \mathrm{ppm}$ & $\mathrm{pH}$ \\
\hline$\# 1$ & $1.62 \times 10^{-4}$ & 0.41 & 0 & 9.3 & 8.1 \\
\hline \#2 & $1.12 \times 10^{-5}$ & 0.04 & 0.02 & 0.6 & 7.9 \\
\hline \#3 & $3.20 \times 10^{-5}$ & 1.13 & 0 & 0 & 7.9 \\
\hline \#4 & $4.24 \times 10^{-5}$ & 1.50 & 0 & 0 & 8.0 \\
\hline
\end{tabular}

Original

Lixiviant

1046

944

$0.5 \quad 8.0$

TABLE 6. Details on Radiosiotope Counting

\begin{tabular}{|c|c|c|c|c|}
\hline Isotope & Energy Level & Type & Abundance, $\%$ & Dectector \\
\hline${ }^{51} \mathrm{Cr}$ & 320 & $\gamma$ & 9 & Intrinsic Germanium \\
\hline $54_{M n}$ & 835 & $\gamma$ & 100 & $\mathrm{Ge}(\mathrm{Li})$ \\
\hline${ }^{59} \mathrm{Fe}$ & 1095 & $\gamma$ & 56 & $\mathrm{Ge}(L i)$ \\
\hline $73_{\text {As }}$ & 54 & $\gamma$ & 9 & Intrinsic Germanium \\
\hline${ }^{75} \mathrm{Se}$ & 136 & $\gamma$ & 57 & Intrinsic Germanium \\
\hline${ }^{109} \mathrm{Cd}$ & 88 & $109_{A g-\gamma}$ & 3.7 & Intrinsic Germanium \\
\hline $210 \mathrm{pb}$ & 46.5 & $\gamma$ & 4 & Intrinsic Germanium \\
\hline${ }^{228} \mathrm{Ra}$ & $904-988$ & $228 A c-\gamma$ & 41 & $\mathrm{NaI}$ \\
\hline
\end{tabular}

Experimental Design

The columns were lucite cylinders sealed with lucite collars and endcaps, as shown in Figure 5 . Each endcap contained an 0-ring which seated against the end of the cylinder and was held by screws through the endcap and collar.

We used four columns for the August 1982 column experiment; each had a nominal pore volume of $150 \mathrm{ml}$ and each was run with a different radiotracer (or set of tracers) in the lixiviant solution. During the November-December 1982 experiment we used two large columns with pore volumes of $300 \mathrm{ml}$ and $600 \mathrm{ml}$ in addition to two columins with pore volumes of $150 \mathrm{ml}$. The larger columns increased the amount of sediment that the lixiviant contacted as it passed through the columin. During the November-December test one of the smaller columns was run with ground water from the ore-zone aquifer.

Liquid entered and exited through holes drilled in the endcaps of the columns. To prevent particle migration, each hole was covered with a spectra mesh nylon filter ( $30-\mu m$ pore size--21\% open area) supported on a stainless steel screen and sealed with a silicone rubber compound. 


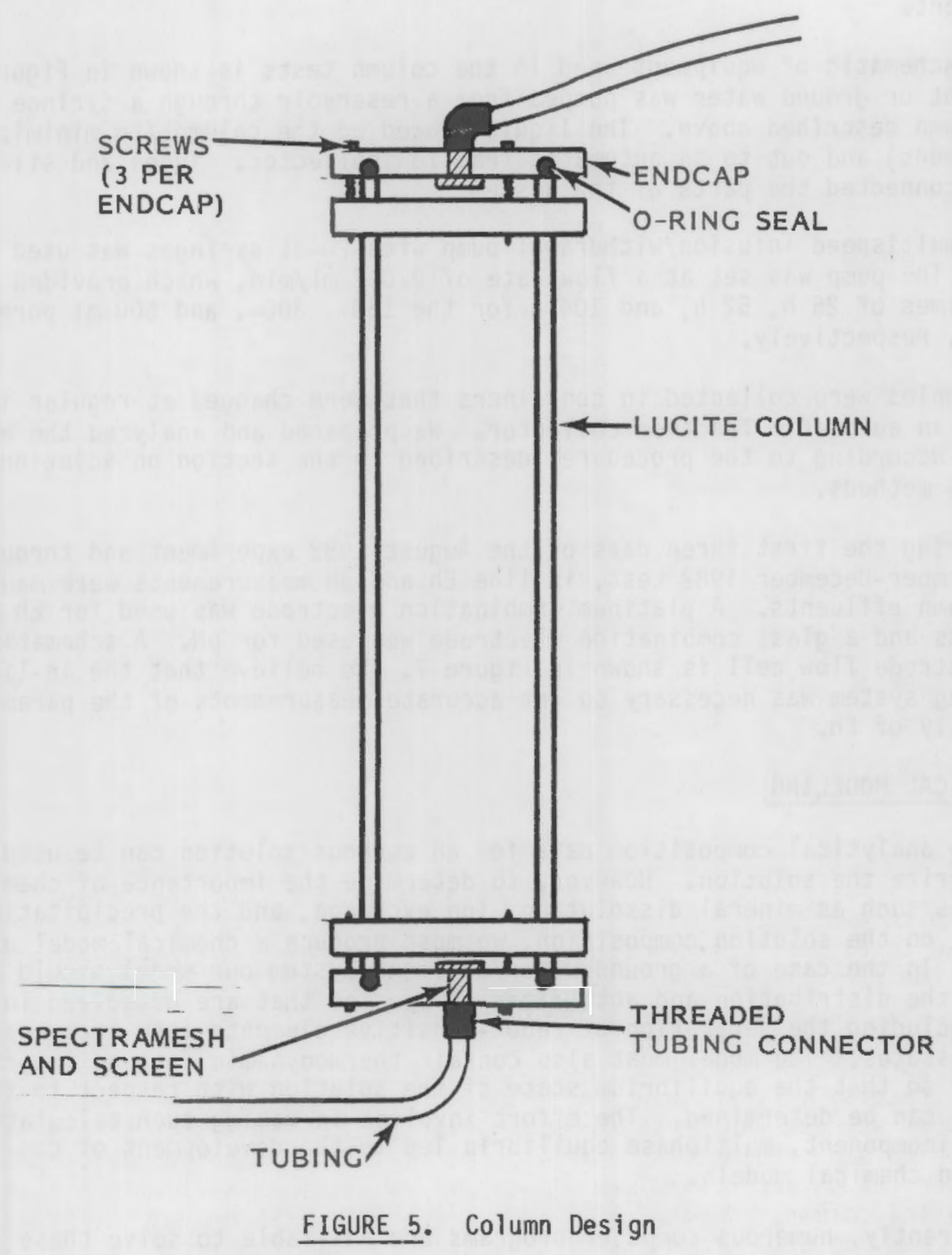


The columns were packed with reduced downgradient sediment in a nitrogen purged glove bag. Each column was packed to a dry density of 1.5 to $1.6 \mathrm{~g} / \mathrm{cm}^{3}$ and was approximately $80 \%$ saturated with pore fluid at the beginning of the experiment.

A schematic of equipment used in the column tests is shown in Figure 6. Lixiviant or ground water was pumped from a reservoir through a syringe pump to the column described above. The liquid flowed up the column (to minimize air entrainment) and out to an automatic fraction collector. Tygon and silastic tubing connected the parts of the system.

A multispeed infusion/withdrawal pump with $20-m l$ syringes was used for all tests. The pump was set at a flow rate of $0.097 \mathrm{ml} / \mathrm{min}$, which provided residence times of $26 \mathrm{~h}, 52 \mathrm{~h}$, and $104 \mathrm{~h}$ for the 150-, 300-, and $600-\mathrm{ml}$ pore volume columns, respectively.

Samples were collected in containers that were changed at regular intervals by an automatic fraction collector. We prepared and analyzed the effluent samples according to the procedures described in the section on solution analysis methods.

During the first three days of the August 1982 experiment and throughout the November-December 1982 test, in-line Eh and $\mathrm{pH}$ measurements were made on the column effluents. A platinum combination electrode was used for En measurements and a glass combination electrode was used for pH. A schematic of the electrode flow cell is shown in Figure 7. We believe that the in-line measuring system was necessary to get accurate measurements of the parameters, especially of Eh.

GEOCHEMICAL MODELING

The analytical composition data for an aqueous solution can be used to characterize the solution. However, to deterimine the importance of chemical processes such as mineral dissolution, ion exchange, and the precipitation of minerals on the solution composition, we must produce a chemical model of the system. In the case of a ground-water/sediment system our model should contain data on the distribution and activities of species that are dissolved in solution, including the separation of redox-sensitive elements into their various valence states. The model must also contain thermodynamic data on important minerals so that the equilibrium state of the solution with respect to those minerals can be determined. The effort involved in making such calculations for multicomponent, multiphase equilibria led to the development of computerized chemical models.

Currently, numerous computer programs are available to solve these problems of simultaneous chemical equilibria and to produce a model for a particular aqueous system. The programs and their development are described by Jenne (1981); Nordstrom et al. (1979) present a comparison of the models produced by 


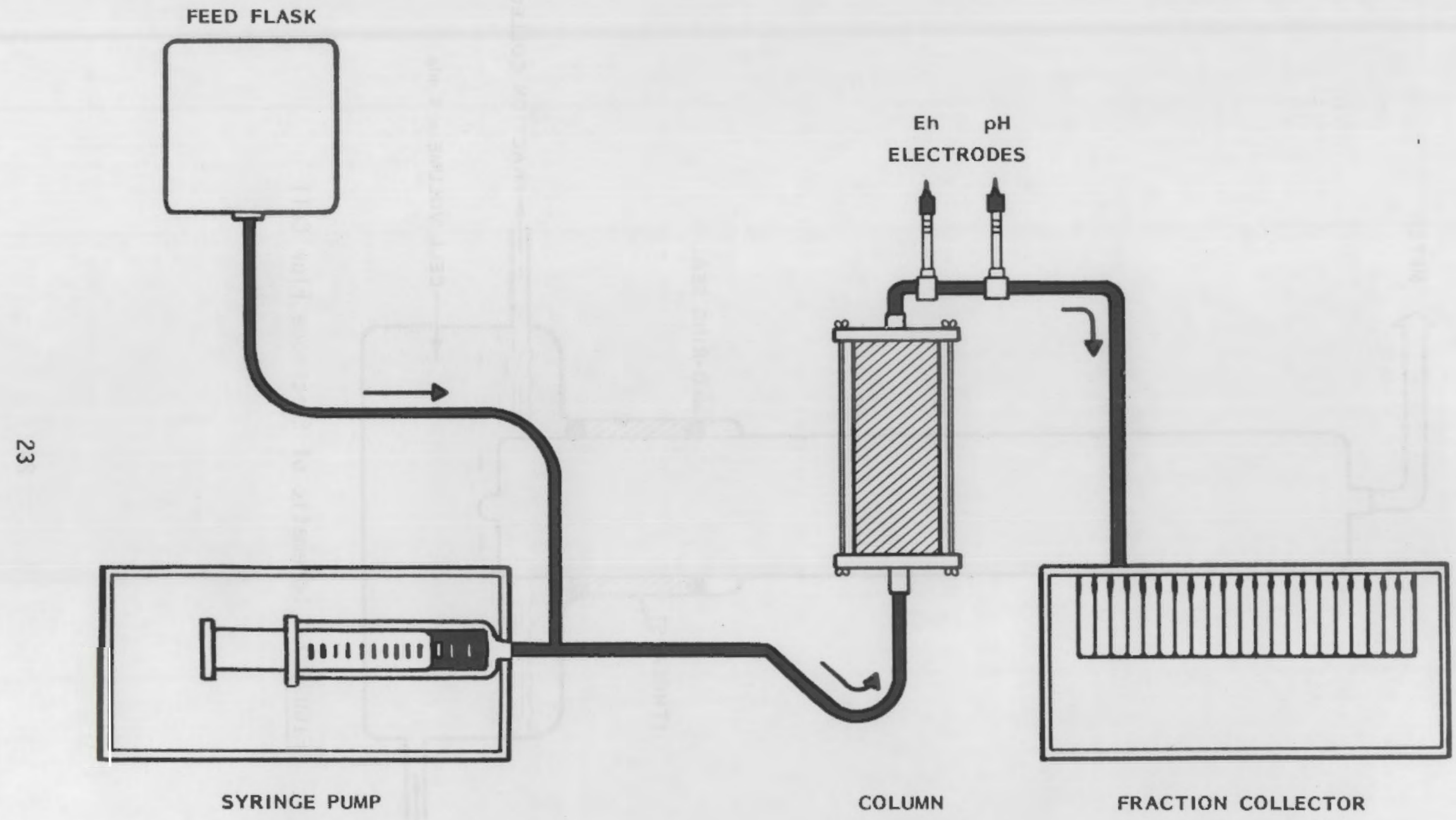

FIGURE 6. Schematic of Column Test Apparatus 


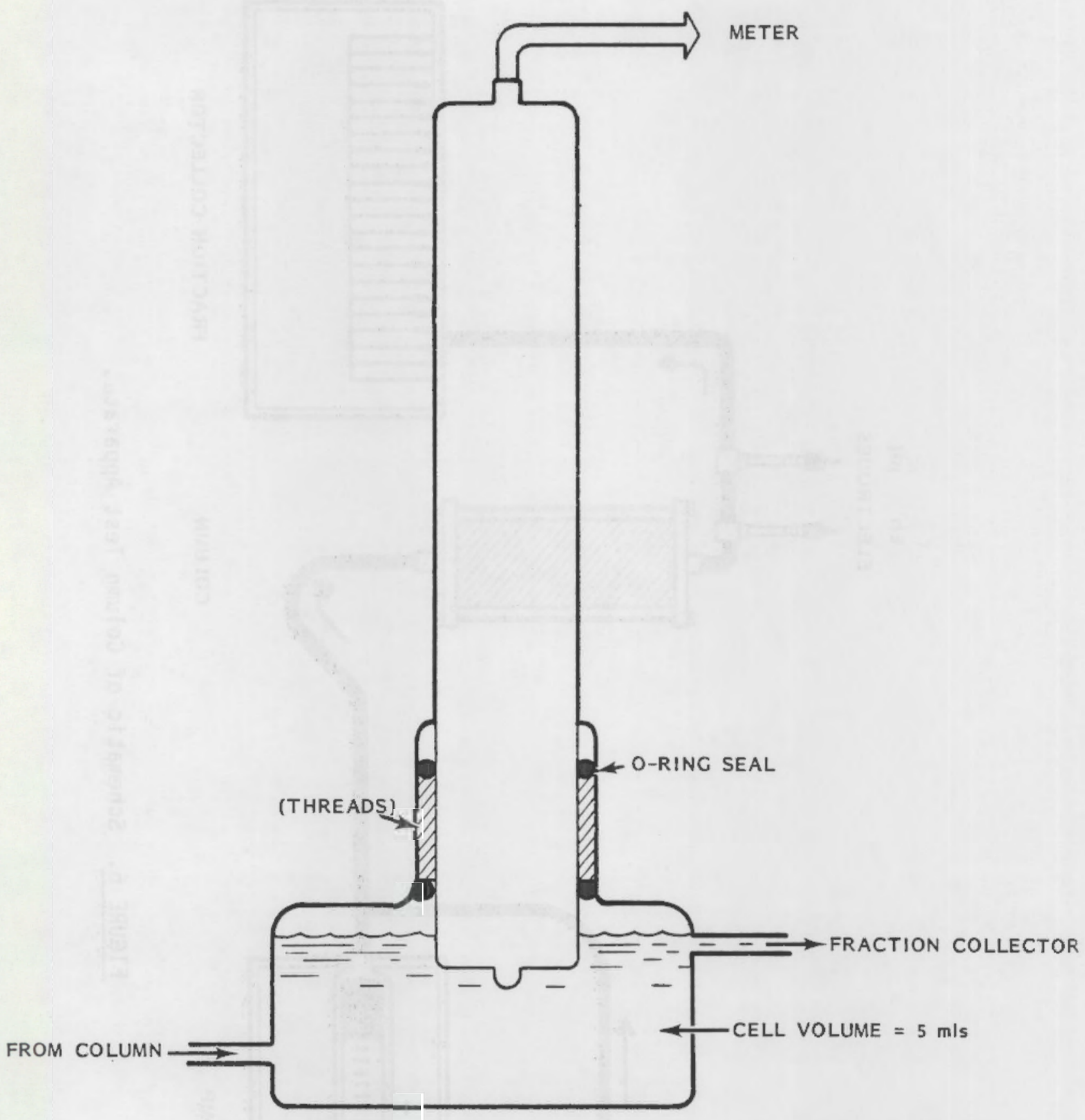

FIGURE 7. Schematic of Electrode Flow Cell 
several of these codes. The MINIEQ code, developed at PNL by A. R. Felmy, D. C. Girvin, and E. A. Jenne, a was used to model the batch solutions and column effluents from these experiments. This code combines the best features of two existing codes: MINEQL (Westall, Zachary and Morel 1976) and WATEQ3 (Ball, Jenne and Cantrell 1981). The principal capability of MINTEQ used in this study was the calculation of the saturation indices of minerals based on the solution composition. The saturation index of a mineral is the log to the base 10 of the ratio of the activity product of the mineral components to the thermodynamic solubility product of the mineral (i.e., S.I. $=\log A P / K_{s p}$ ). A saturation index of zero means that the mineral is in equilibrium with the solution; values greater than zero indicate oversaturation and those less than zero mean undersaturation. The results of the experiments show that these calculations are very useful in interpreting the data and in determining the chemical processes that have occurred in the solution/sediment systems.

(a) Felmy, A. R., D. C. Girvin and E. A. Jenne. 1983. MINTEQ - A Computer Program for Calculating Aqueous Geochemical Equilibria. Battelle, Pacific Northwest Laboratories, Richland, Washington (to be published). 



\section{RESULTS AND DISCUSSION}

Our results thus far of the study on natural restoration of ground water are derived from data on the lixiviant and ground-water chemistry at the mine site and from the batch and column tests described above. The site characterization and laboratory test results are discussed in this section.

\section{LIXIVIANT AND GROUND WATER}

The field and laboratory analyses of lixiviant and ground waters sampled during March 1982 at the Benavides mine are summarized in Table 7 . The type of solution sampled is listed under well type; the location of the wells is shown in Figure 3. The effect of long-term storage on solution composition is discussed in Appendix $A$, which also contains a list of suggested analytical techniques to use for the analysis of similar solutions.

In the following three sections we compare the compositions of the lixiviant and ground water and discuss possible excursion detection parameters and the setting of restoration criteria based on the measured chemical differences.

Solution Composition

The lixiviant, as characterized by samples from production Wells 158 and 666 , contains high total dissolved solids (TDS >4,000 ppm) compared to the ground water (average TOS $<1,500 \mathrm{ppm}$ ). The concentration of each major cation and anion is also greater in the lixiviant compared to the ground water; however, the ratio of concentrations varies significantly by element. We computed the ratio of major ion concentrations in the lixiviant and ground water by using average concentration values for the two production wells and representing the ground-water composition of the ore-zone aquifer as the average of Wells $691,809,831,844,907,912,915,929,957$, and 958 (see Table 8). The concentrations of $\mathrm{Ca}, \mathrm{Mg}$, and $\mathrm{SO}_{4}$ are highly elevated in the lixiviant, compared to the ground water. The lixiviant used at this leach facility is ground water fortified with oxygen and carbon dioxide gas, neither of which would directly add $\mathrm{Ca}, \mathrm{Mg}$, or $\mathrm{SO}_{4}$ to the solution. Their large rise in concentration must, therefore, be due to interactions between the lixiviant and sediment. The lixiviant is designed to oxidize uranium in the sediment; however, sulfide minerals will also be oxidized during leaching of uranium and this reaction will either directly or indirectly lead to increases in $\mathrm{Ca}, \mathrm{Mg}$, and $\mathrm{SO}_{4}$. The oxidation of pyrite $\left(\mathrm{FeS}_{2}\right)$, which is a common constituent of the reduced zones of the ore-zone aquifer, produces $\mathrm{SO}_{4}$ and adds hydrogen ions to the solution [Equation (1)]:

$$
2 \mathrm{FeS}_{2}+7.5 \mathrm{O}_{2}+7 \mathrm{H}_{2} \mathrm{O}=2 \mathrm{Fe}(\mathrm{OH})_{3}+4 \mathrm{SO}_{4}^{\bar{z}}+8 \mathrm{H}^{+}
$$

The hydrogen will react with dolomite $\left[\mathrm{CaMg}\left(\mathrm{CO}_{3}\right)_{2}\right]$ and magnesium-rich calcite $\left(\mathrm{Ca}_{1-\mathrm{x}} \mathrm{Mg}_{\mathrm{x}} \mathrm{CO}_{3}\right.$ ), which will buffer the solution and release $\mathrm{Ca}$ and $\mathrm{Mg}$. $\mathrm{An}$ idealized reaction is shown in Equation (2):

$$
\mathrm{CaMg}\left(\mathrm{CO}_{3}\right)_{2}+2 \mathrm{H}^{+}=\mathrm{Ca}^{2+}+\mathrm{Mg}^{2+}+2 \mathrm{HCO}_{3}^{-}
$$


TABLE 7. Solution Characteristics of URI's Benavides Wells (concentration units are $\mathrm{mg} / \mathrm{L}$ )

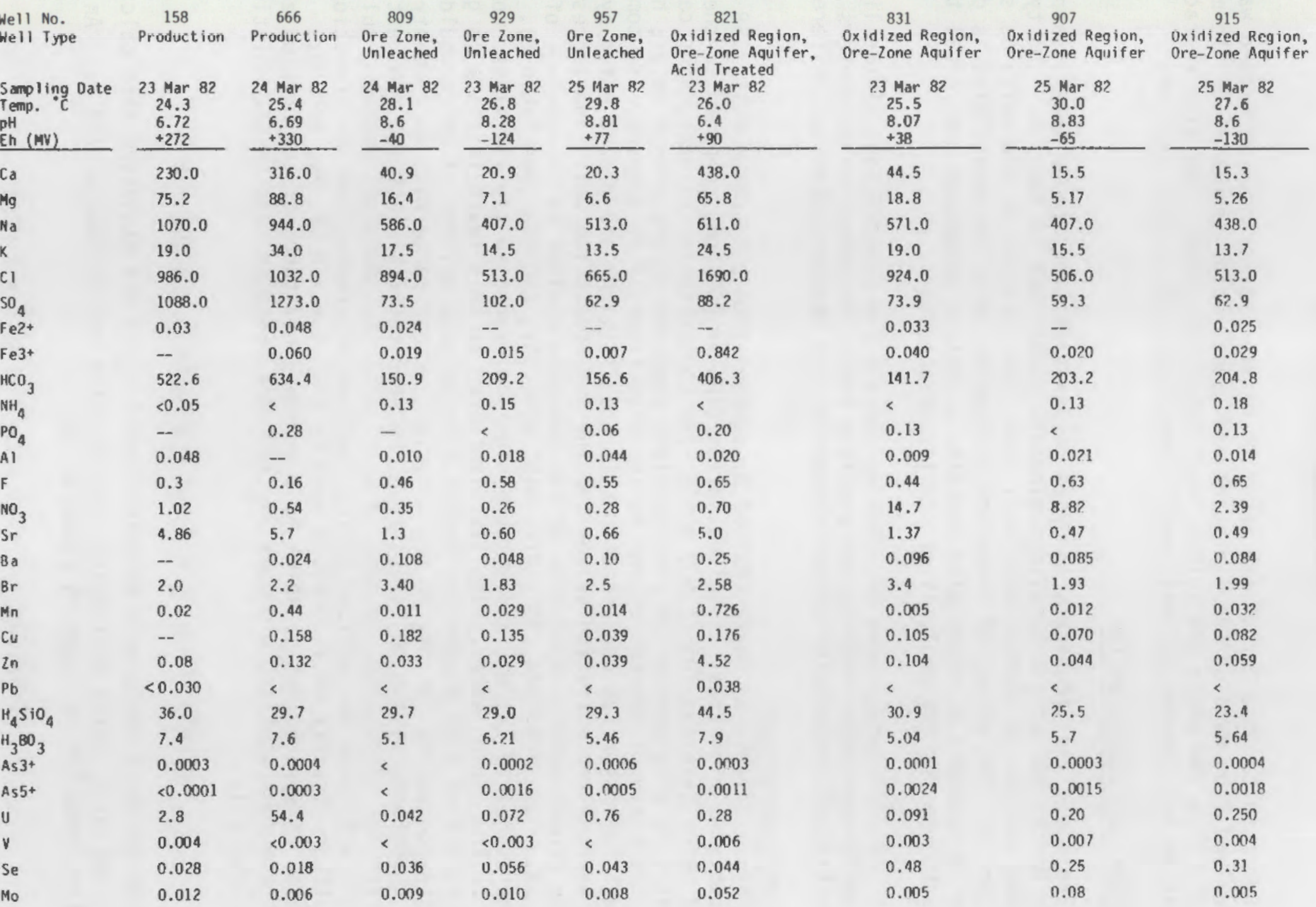




\section{TABLE 7. (contd)}

Well No. Well Type

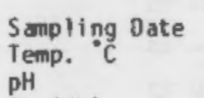

Eh (HV)

Ca

Mg

Na

K

$\mathrm{Cl}$

$\mathrm{SO}_{4}$

$\mathrm{Fe}^{+}+$

$\mathrm{Fe}^{+}$

$\mathrm{HCO}_{3}$

ก
Oxidized 990

844 Acid

24 Mar 82

912

$\begin{array}{lll}\text { Perimeter well, } & \text { Reduced Region, } & \text { Reduced Region, } \\ \text { 0xidized Region } & \text { Ore-Zone Aquifer Ore-Zone Aquifer }\end{array}$

Ore-Zone Aquifer

25 Mar 82

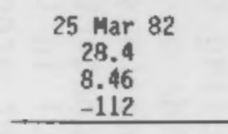

5.6

$\frac{+99}{10,380.00}$

666.0

1168.0

67.0

$21,644.0$

93.0

$-$

193.0

746.6

$<$

4.91

1.56

1.0

90.5

55.4

4.1

5.0

28.0

2.34

52.6

0.90

136.0

4.4

$<0.0001$

0.0009

1.03

0.007

0.01

0.02 .

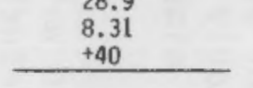

49.9

18.2

603.0

16.5

949.0

86.3

0.010

0.010

114.3

$<$

0.07

0.011

0.4

15.5

1.6

0.108

3.5

0.009

0.059

0.034

$<0.030$

37.4

4.9

0.0046

0.027

0.026

0.003

0.079

0.173
0.00

0.05

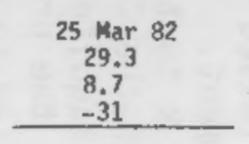

22.8

7.37

527.0

17.0

771.0

76.0

0.01

0.02

139.1

0.06

0.08

0.027

0.53

3.72

0.70

0.083

2.62

0.019

0.071

0.059

$<$

26.6

5.2

0.0047

0.0042

0.17

0.060

0.096
691

Perimeter Well, Reduced Region, Ore-Zone Aquifer
$25 \mathrm{Mar} 82$

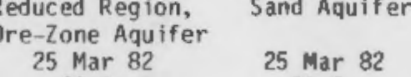

Monitor D, Monitor 0

Monitar 0 ,
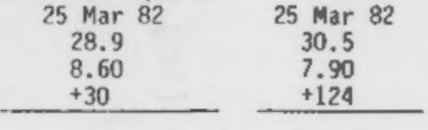

Sand Aquifer

6.26

477.0

13.5

620.0

$48 . ?$

0.010

0.016

185.8

$<$

0.076

0.015

0.46

$<$

0.53

0.112

2.2

0.003

0.117

0.026

$<$

28.4

5.23

-.

0.053

$<$

0.036

0.005

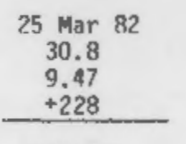

37.8

24.4

565.0

22.0

888.0

156.3

--

0.035

83.0

0.16

$<$

0.051

0.27

19.7

1.36

0.079

3.22

0.002

0.166

0.043

$<$

25.0

5.1

0.0016

0.0068

0.083

0.026

0.013

0.008
25 Mar B?

27.1
8.49

$+86$

23.9

512.0

21.0

668.0

109.0

0.020

0.032

0.15

0.009

0.022

0.47

10.3

1.09

0.087

2.60

0.024

0.097

0.082

$<$

5.1

0.0020

0.0119

0.036

0.006

0.020

0.058 
TABLE 8. Mean Concentration and Standard Deviation of Selected Constituents in the Ground Water and Lixiviant

\begin{tabular}{|c|c|c|c|c|c|}
\hline & \multirow{2}{*}{$\begin{array}{l}\text { Ground } \\
\overline{\bar{x},}, \mathrm{ppm} \\
\end{array}$} & \multirow{2}{*}{$\begin{array}{c}\text { Water } \\
\sigma \\
\end{array}$} & \multicolumn{2}{|c|}{ Lixiviant } & \multirow{2}{*}{$\begin{array}{r}\text { Concentration Ratio } \\
\text { Lixiviant/Ground Water } \\
\end{array}$} \\
\hline & & & $\bar{x}, p p m$ & $\sigma$ & \\
\hline $\mathrm{Ca}$ & 25.9 & 14 & 273.0 & 61 & 10.5 \\
\hline $\mathrm{Mg}$ & 9.6 & 5.8 & 82.0 & 10 & 8.5 \\
\hline $\mathrm{Na}$ & 486 & 90 & 1007 & 89 & 2.1 \\
\hline K & 15.2 & 2.3 & 26.5 & 11 & 1.7 \\
\hline C & 677 & 196 & 1009 & 33 & 1.5 \\
\hline $\mathrm{SO}_{4}$ & 71.1 & 15 & 1181 & 131 & 16.6 \\
\hline $\mathrm{HCO}_{3}$ & 173 & 36 & 579 & 79 & 3.3 \\
\hline $\mathrm{pH}$ & 8.53 & 0.24 & 6.71 & 0.02 & $1.3(\log$ units) \\
\hline U & 0.17 & 0.21 & 28.6 & 36.4 & 168. \\
\hline
\end{tabular}

In addition to dissolving carbonate minerals, hydrogen released by sulfide oxidation will hydrolyze silicate minerals present in the sediment. The primary silicates will alter to form clays and will add $\mathrm{Na}$ and $\mathrm{K}$ to the solution. These elements may also be added through ion exchange of the $\mathrm{Ca}$ and $\mathrm{Mg}$ in the lixiviant for $\mathrm{Na}$ and $\mathrm{K}$ sorbed onto surface sites of the aquifer minerals. A third source of $\mathrm{Na}$ is through treatment undergone by the pregnant lixiviant to remove the uranium. Anion exchange columns are used to extract the carbonate-complexed uranium from the lixiviant before recycling the lixiviant back to the aquifer. The uranium complex displaces chloride on the exchange resin, and the resin is flushed with $\mathrm{NaCl}$ solution, and thus stripped of uranium after it is fully loaded. If any of the lixiviant contacts residual $\mathrm{NaCl}$ solution, $\mathrm{Na}$ is added to the lixiviant. The increase in $\mathrm{Cl}$ in the lixiviant (compared to the ground water) is also due to the treatment process. The increase in bicarbonate concentration in the lixiviant is probably caused by the $\mathrm{CO}_{2}$ added to the solution and the dissolution of carbonate minerals [see Equation (2)].

The trace metal content of the lixiviant and of the ground waters sampled from the Benavides Site are generally very low, if not below detection limits. The concentrations of $\mathrm{As}, \mathrm{Ba}, \mathrm{Cd}, \mathrm{Cr}, \mathrm{Pb}, \mathrm{Ag}, \mathrm{Cu}, \mathrm{Fe}$, and $\mathrm{Zn}$ do not exceed EPA primary and secondary drinking water standards (40 CFR 141 and 40 CFR 143, respectively). Selenium is present in the two lixiviants sampled at 0.018 and $0.028 \mathrm{ppm}$, which exceeds its maximum concentration level (MCL) of 0.01 . However, selenium is also present in the ground water at a concentration of $0.48 \mathrm{ppm}$ (Well 831); therefore, mining has not generated the hazard. Manganese exceeds its secondary $\mathrm{MCL}(0.05 \mathrm{ppm})$ in one of the lixiviants (Well 666 , $0.44 \mathrm{ppm}$ ) as well as in one of the monitoring wells in the D sand aquifer (Well 846, 0.08 ppm). 
Excursion Detection Parameters

The early detection of a loss of fluid control during leaching (an excursion) is necessary to limit the spread of the lixiviant, and thus, to limit environmental impact. Monitoring wells located around the periphery of the leach field are sampled periodically to detect excursions. The choice of parameters to be measured will determine the likelihood of early detection and minimize the possibility of incorrectly identifying natural variations as excursions. The measured value of the excursion indicator (e.g., solution pH or concentration of dissolved constituent) should differ considerably between the lixiviant and the ground water, and its characteristic signature in the lixiviant should not be modified by interactions between the lixiviant and the aquifer sediment. Table 8 can be used to compile a tentative list of excursion indicators. The concentration of the components listed in Table 8 is appreciably higher in the lixiviant than in the ground water; however, the $\mathrm{Cl}$ concentration in the ground water is within two standard deviations of the lixiviant concentration and for this reason $\mathrm{Cl}$ would probably not be a good indicator at this site. Calcium, magnesium, and sulfate concentrations are much greater in the lixiviant than in the ground water, and, based on this criterion alone, they would appear to be the best indicators. However, the transport of cations in the ground water will be retarded by ion exchange between the solution and the sediments, and sulfate concentration may be reduced as a result of oxidation-reduction reactions to form new sulfide minerals. Uranium may be one of the best excursion indicators because its concentration is generally orders of magnitude higher in the lixiviant and it exists in solution as an anion, which would not be as susceptible as a cation to exchange processes with the aquifer minerals. However, uranium is redoxsensitive and may be reprecipitated, thus reducing the uranium concentration in the solution as the lixiviant moves out from the leach field. This possibility is discussed with the results of the column experiments.

Potter et al. (1979) monitored the composition of formation water at various time stages during leaching of an ore body to evaluate the migration rates of the various solution constituents in the lixiviant. They found that the migration rates decreased in the following order: $\mathrm{H}>\mathrm{HCO}_{3}>\mathrm{Mg}>\mathrm{Cl}>$ $\mathrm{Na}>\mathrm{K}>\mathrm{Ca}>\mathrm{NH}_{4}$ for the ore zone they studied, which is also located in southern Texas. Based on their results and on the data in Table 8, the hydrogen activity in the lixiviant (which is 20 times that of the ground water) appears to be an excellent excursion indicator at the Benavides Site. However, the wells sampled in the Potter study are all fairly close to the injection zone $(<25 \mathrm{~m})$; we question whether the low pH of the lixiviant could be maintained as the water moved to monitoring wells, typically located 30 to $60 \mathrm{~m}$ from the edge of the leach field.

The ion-exchange reactions that retard the movement of several of the cations in the aquifer would have little effect on the total dissolved solids level (measured in equivalents per liter); consequently, monitoring TDS by measuring changes in specific conductivity of the fluid could indicate an excursion. Although precipitation of solids as the lixiviant reacts with the reduced sediments of the aquifer would reduce TDS somewhat, the TDS level should remain elevated for an appreciable distance away from the leach zone. 
In summary, an anion that is not reactive would be the best choice for an indicator. Chloride would be the obvious choice if its concentration in the lixiviant and ground water is statistically different. Sulfate is reactive but its concentration in the lixiviant is much higher than in the ground water. Also, the rate of sulfate reduction may be sufficiently slow in the aquifer so that the escaped lixiviant can maintain a high sulfate concentration for a long travel distance from the leach field. The total dissolved solids level of the water appears to be least affected by chemical processes that might occur if lixiviant flowed from leach field to the monitoring wells and should be a good indicator of an excursion. Regardless of which indicators are chosen to establish whether or not an excursion has taken place, the setting of an upper control limit for that parameter must involve an analysis of natural variations.

\section{Restoration Criteria}

There are large standard deviations ( 15 to $60 \%$ of the mean) for all the constituents, except hydrogen, listed in Table 8 . This shows that the water in the aquifers containing the uranium deposits are not very uniform. Consequently, ground-water restoration criteria that are set for this site must take into account the obvious spatial variation in water composition and an expected temporal variation as well. Restoration criteria should be based on a statistical analysis of solution chemistry data from a set of wells sampled over a sufficiently long time period to determine the temporal variation. Rothrock (1981) describes statistical techniques for analyzing ground-water quality data.

As far as EPA standards are concerned, the solution constituents of primary interest for restoration at the Benavides site (based on their elevated concentrations in the lixiviant and expected difficulty of removal from the aquifer) are uranium, sulfate, and the total dissolved solids in the lixiviant. The effect of natural restoration on lowering the concentration of uranium, sulfate, and other potentially important redox-sensitive elements is described with the results of the batch and column experiments. The total dissolved solids level can be lowered by a number of induced restoration techniques and the level will also naturally decline in the aquifer through mixing and diffusion.

\section{BATCH EXPERIMENTS}

As desribed in the methodology section, we conducted batch experiments to characterize the $\mathrm{pH}$, Eh, and dissolved oxygen content of the lixiviant and mixtures of lixiviant and distilled water with sediments from the ore-zone aquifer. We also analyzed the composition of solutions from some of these tests. The following two sections discuss the results of the batch tests.

Response of Solution $\mathrm{pH}, \mathrm{Eh}$, and Dissolved Oxygen Content to Gas Purging and Sediment Interactions

To evaluate the effect of dissolved oxygen on the Eh of the solutions used in the experiments and to test the reliability of the glove bags and controlled 
atmosphere chambers, we measured the $\mathrm{pH}$, Eh, and dissolved oxygen content of lixiviant alone in test series number 1 . In Test $1 \mathrm{~A}$ lixiviant was exposed to the open atmosphere; in Test $1 B$ it was enclosed in a nitrogen glove bag; in Test $1 C$ it was in a controlled-atmosphere (argon) chamber. The results of these tests are shown in Figure 8 . The first measurements (Test 1A) were taken on lixiviant exposed to air. Under these conditions the lixiviant had an Eh of $+310 \mathrm{mv}$, pH of 7.5, and dissolved oxygen content of $8.9 \mathrm{ppm}$. The Eh value is consistent with that of other solutions of this $\mathrm{pH}$ exposed to the atmosphere, but it is well below the theoretical Eh (+778 mv) that can be computed by assuming equilibrium between the solution and oxygen in the atmosphere. The well-known disequilibrium between atmospheric partial pressure of oxygen and solution Eh (Baas-Becking, Kaplan and Moore 1960) has been attributed by Sato (1960) to the existence of a rate-controlling step involving hydrogen peroxide rather than the oxidation of water.

Although the Eh of a solution may not be directly derived from a measurement of the partial pressure of oxygen in the vapor phase, the results of Tests $1 B$ and $1 C$ indicate that the $E$ h is affected by the dissolved oxygen content of the solution. In these two tests we purged the lixiviant of dissolved gases with either nitrogen (Test 1B) or argon (Test 1C). Nitrogen purging was done in a plastic glove bag and argon was used in a controlledatmosphere chamber. In both cases the dissolved oxygen content of the solution dropped dramatically and Eh was lowered; however, the change in these parameters was not as great in the glove bag as in the chamber, probably because of the lack of an active oxygen scavenger in the glove bag and because of difficulties encountered in sealing its ports. The rise in $\mathrm{pH}$ measured during purging is probably caused by the stripping of $\mathrm{CO}_{2}$ gas from the solution. The rise in $\mathrm{pH}$ for the nitrogen-purged solution (Test $1 \mathrm{~B}$ ) resulted in the precipitation of a carbonate mineral on the electrode, which in turn resulted in the erratic readings of $\mathrm{pH}$ shown during the latter part of the test. If oxygen is removed from ground water by some restoration technique, the redox potential of the solution should decrease, thereby reducing the solubility of some redoxsensitive minerals (e.g., uraninite and sulfides). However, the pH should not be raised high enough to precipitate carbonates and possibly plug portions of the aquifer.

Tests $2 \mathrm{~A}, 2 \mathrm{~B}$, and $2 \mathrm{C}$ studied the effect on the solution of contacting lixiviant with sediments from the reduced zone. Figure 9 shows the changes in $\mathrm{Eh}, \mathrm{pH}$, and dissolved oxygen content due to this interaction for these three tests. In Test $2 \mathrm{~A}$ lixiviant and sediment were mixed in a container open to the atmosphere. The initial drop in Eh can be attributed to the reducing potential of the sediment; however, the capacity of the system exposed to oxygen in the atmosphere is not great as can be seen by the return to apparent equilibrium with the atmosphere after a few hours time. Tests $2 B$ and $2 C$ were conducted in a glove bag purged with nitrogen and in a controlled-atmosphere chamber purged with argon, respectively. The Eh of the lixiviant for Test $2 \mathrm{C}$ starts out much lower (by $130 \mathrm{mv}$ ) than that for Test 2B because the $2 \mathrm{C}$ lixiviant was purged of gases with argon before the test. In both of these tests the sediment lowers the Eh of the solution by approximately $100 \mathrm{mv}$; however, over the period of a 


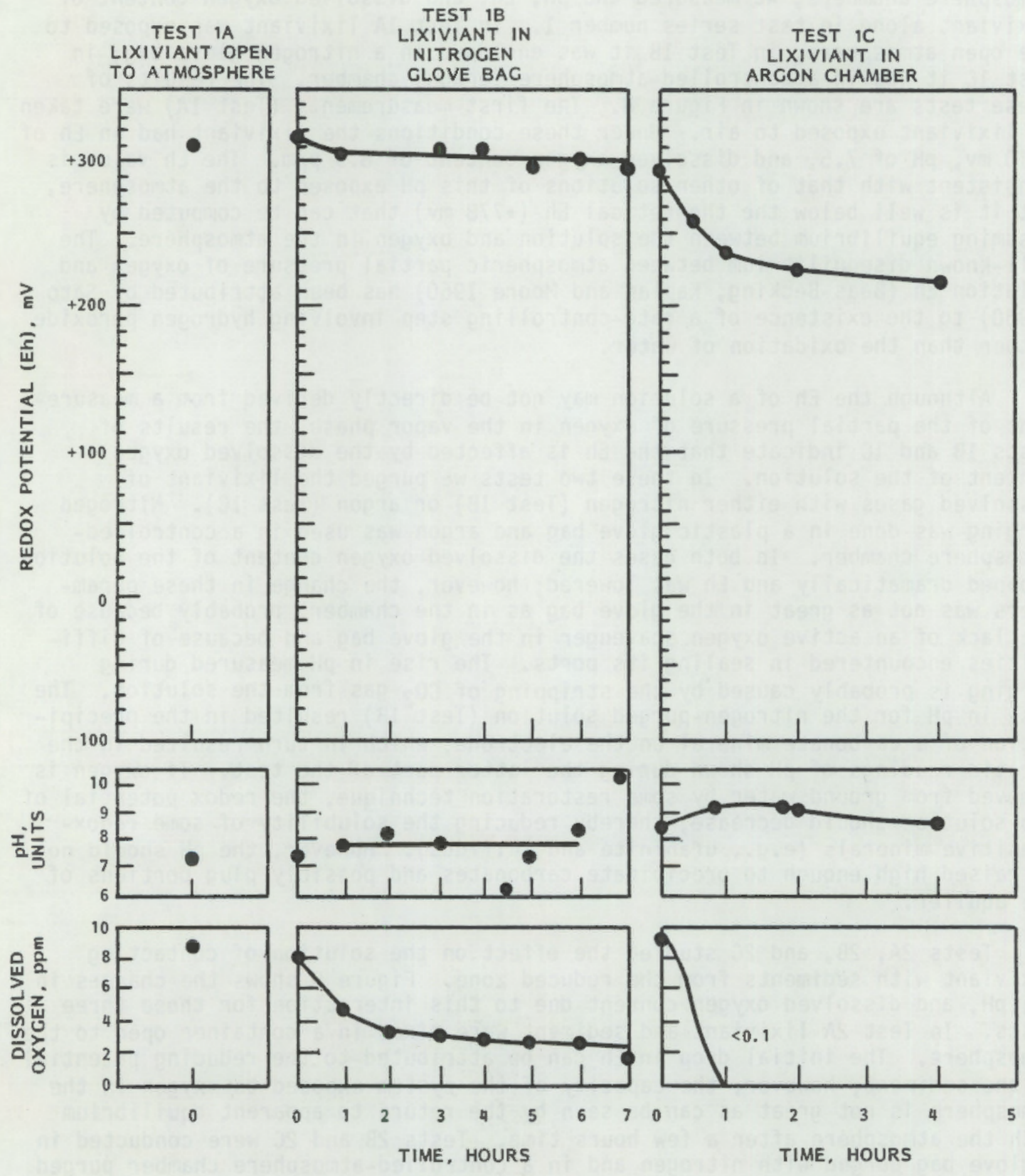

FIGURE 8. Lixiviant Batch Tests IA, 1B, and IC 

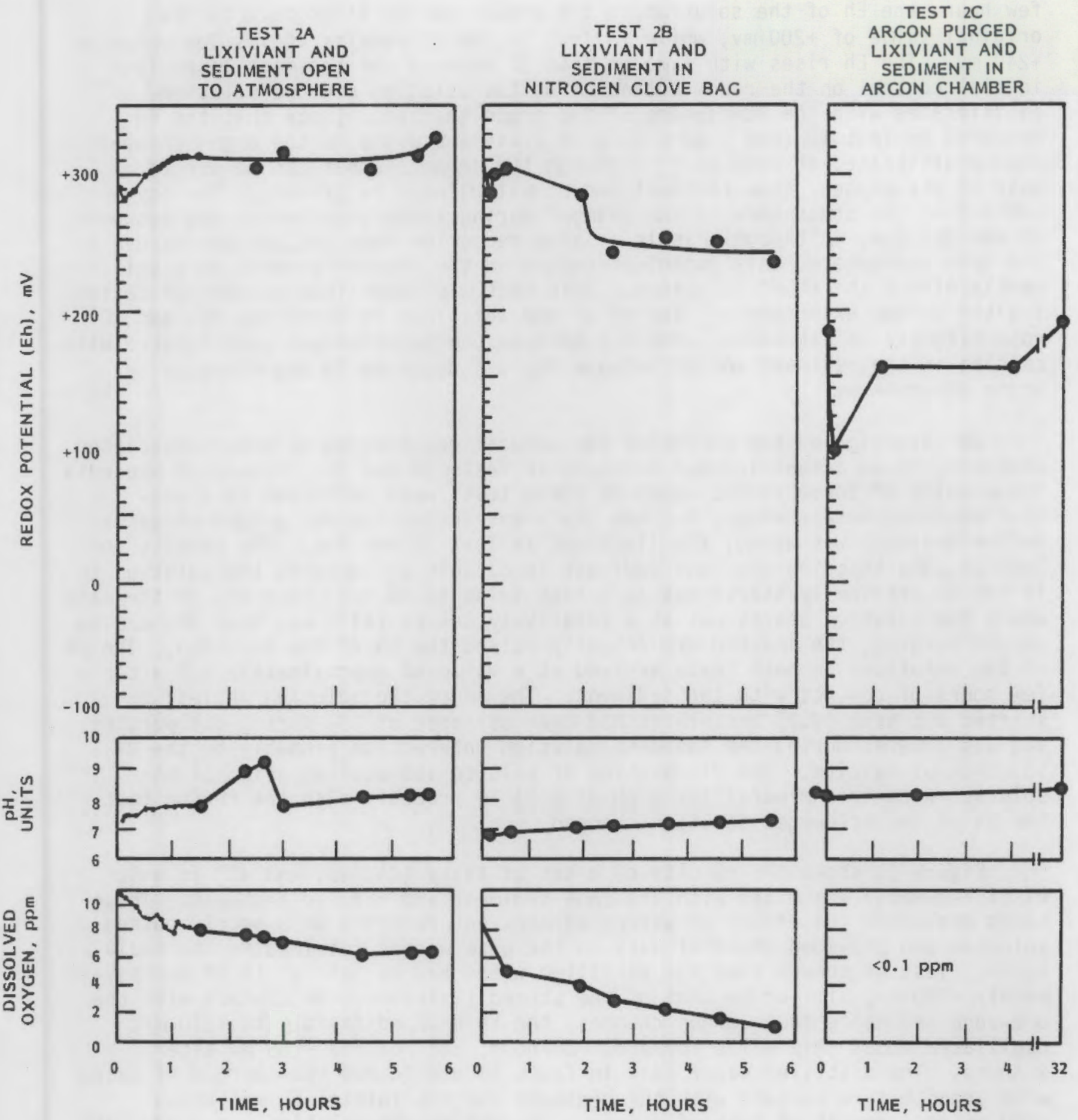

FIGURE 9. Lixiviant/Reduced-Sediment Batch Tests $2 \mathrm{~A}, 2 \mathrm{~B}$, and $2 \mathrm{C}$ 
few hours the Eh of the solution in the argon chamber rises back to its original value of $+200 \mathrm{mv}$, while in Test $2 \mathrm{~B}$ the Eh remains at its low value of $+240 \mathrm{mv}$. The Eh rises with time in Test $2 \mathrm{C}$ because the sediment loses its initial control on the redox potential of the solution and the solution equilibrates with the atmosphere of the argon chamber. [Note that the Eh measured in Test $1 \mathrm{C}$ (see Figure 8 ) with lixiviant alone in the argon chamber also equilibrated at $+200 \mathrm{mv}$.] Although the argon chamber can be purged of most of its oxygen, some residual amount will always be present. The oxygen content of the atmosphere in the chamber during these experiments was between 80 and $100 \mathrm{ppm}$. Although this is a large reduction from 200,000 ppm oxygen in the open atmosphere, this amount of oxygen in the chamber appears to significantly affect the Eh of solutions. This fact was taken into account in designing the column experiments. The $\mathrm{pH}$ of the solutions in Tests $2 \mathrm{~A}, 2 \mathrm{~B}$, and $2 \mathrm{C}$ rose slightly in all cases, probably because the solution was equilibrated with calcite in the sediment and/or because $\mathrm{CO}_{2}$ was degassed in the nitrogen or argon atmospheres.

We investigated the potential for natural restoration by redox-associated processes in an actual leached sediment in Tests $3 \mathrm{~A}$ and $3 \mathrm{~B}$. Figure 10 presents the results of these tests. Both of these tests were performed in a controlled-atmosphere chamber, but the lixiviant in Test $3 \mathrm{~B}$ was purged of gases before sediment was added; the lixiviant in Test $3 \mathrm{~A}$ was not. The results for Test $3 A$ show that the ore-zone sediment is capable of lowering the solution Eh if the Eh originally starts out at a high value (+330 mv); however, in the case where the solution starts out at a relatively low Eh $(+170 \mathrm{mv}$, Test $3 B)$ due to oxygen purging, the leached ore actually raised the Eh of the solution. The pH of the solutions in both tests arrived at a value of approximately 8.5 after a few hours of contact with the sediment. The $\mathrm{pH}$ of the solution in Test $3 \mathrm{~B}$ started out high (9.2) because it had been stripped of $\mathrm{CO}_{2}$ during gas purging, and was lowered during the sediment/solution interaction probably by the dissolution of calcite. The dissolution of calcite and equilibration of the solution with this mineral (at a pH of 8.3 ) is probably also the reason that the $\mathrm{pH}$ of the nonpurged solution changed.

Figure 11 shows the results of a set of tests (4A, 4B, and $4 C$ ) in which distilled water was mixed with ore-zone sediment and reduced sediment. These tests evaluated the effect of water/sediment interactions on a poorly poised solution and provided chemical data on the pore waters retained in the sediments. Test $4 \mathrm{~A}$ showed that the distilled water had an initial Eh of approximately $+330 \mathrm{mv}$, similar to that of the stored lixiviant. On contact with the ore-zone sediments in an argon chamber, the Eh dropped rapidly to $+210 \mathrm{mv}$, oscillated about this value for about an hour, and reached +205 my after 2 hours. The distilled water used in Tests $4 B$ and $4 C$ had been purged of gases with argon before contact with the sediment and its initial Eh was below $+200 \mathrm{mv}$ as a result of loss of oxygen. In Test 4B the solution was mixed with reduced sediment. The Eh dropped to approximately $+100 \mathrm{mv}$ and remained close to this value for approximately 3 hours. The container was then capped and stored overnight in the chamber. The following morning the container was opened and the Eh was monitored for a 1-hour period. The Eh had risen 50 mv during the night but dropped down again to +100 mv during this 1 -hour period. 

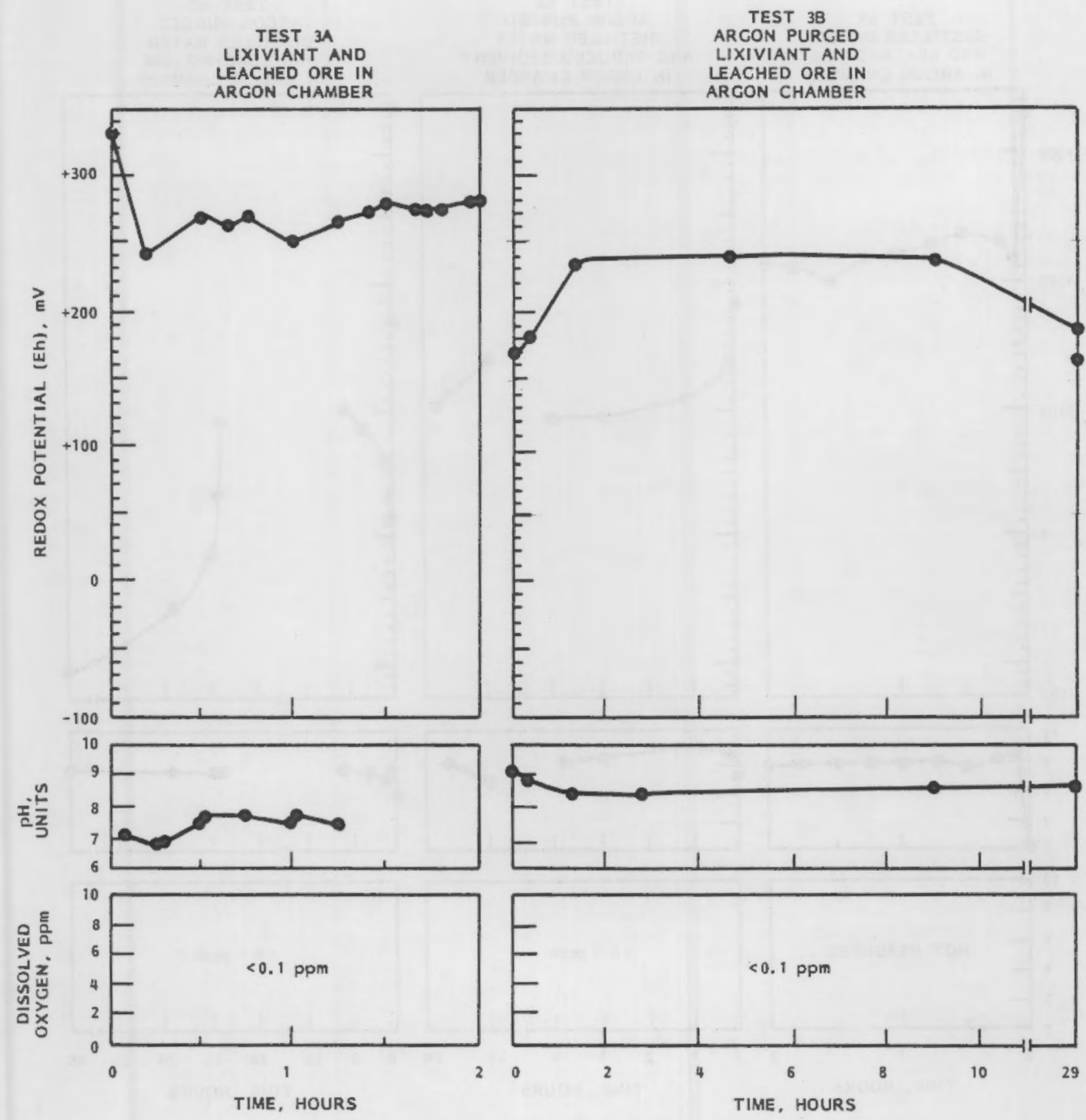

FIGURE 10. Lixiviant/Leached-Ore Batch Tests $3 A$ and $3 B$ 

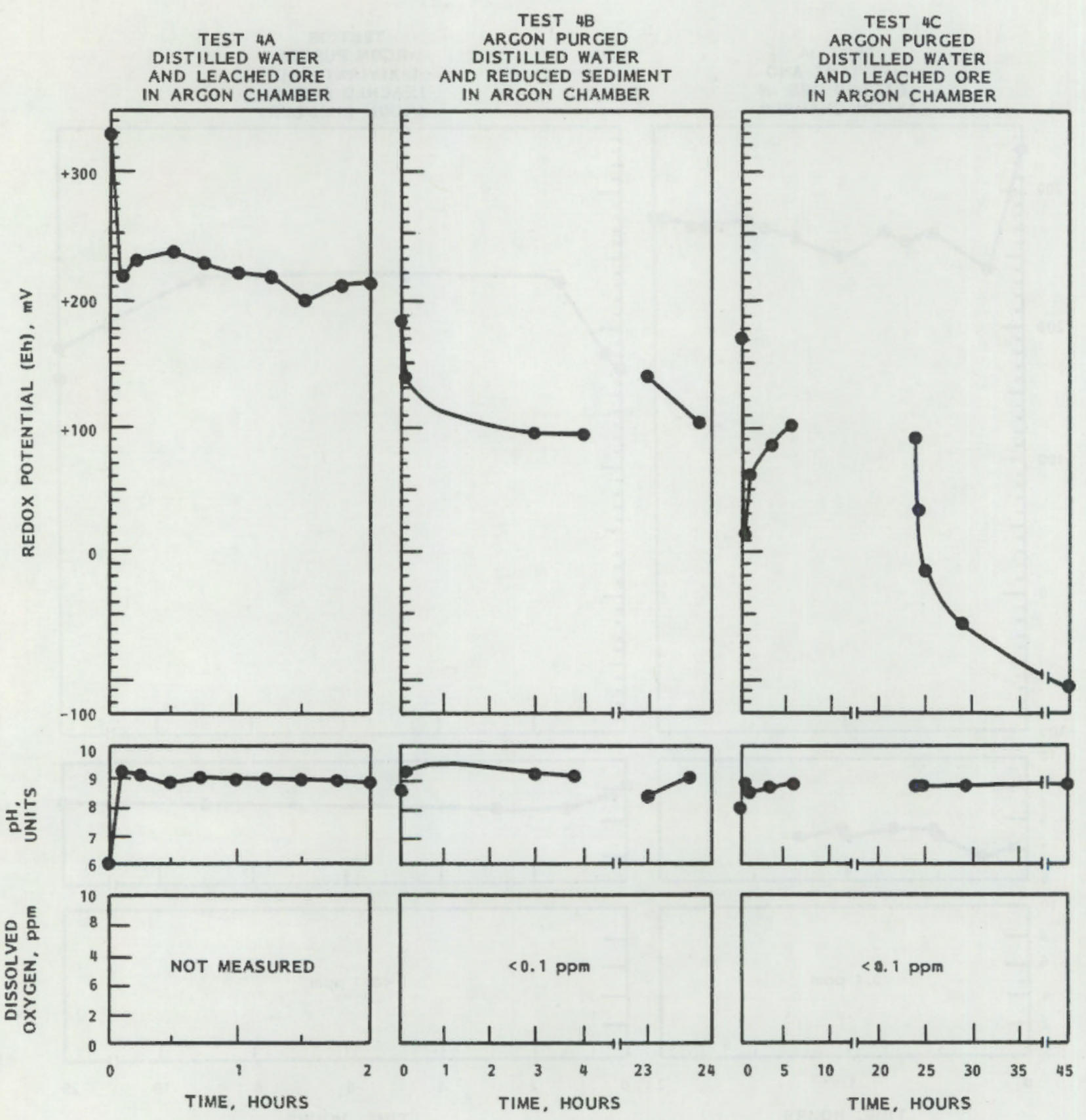

FIGURE 11. Distilled Water/Sediment Batch Tests $4 A, 4 B$, and $4 C$ 
This latter effect may have been due to photosensitive reducing bacteria that responded to the room lights being switched on while the Eh was measured. A similar but more dramatic trend in Eh was noted in Test $4 C$, when purged distilled water was mixed with leached ore. After the initial large drop in Eh the value increased to $+100 \mathrm{mv}$, at which time the sample was capped and stored for the night. When the sample was reopened the next day, the Eh declined from $+90 \mathrm{mv}$ to $-10 \mathrm{mv}$ within the period of an hour, and then made a slow decline to $-110 \mathrm{mv}$ over the following 20 hours. The hypthesis that bacteria are affecting the redox reactions in the solutions requires further testing. Bacteria enhancement of restoration may even prove to be feasible. By comparing Figure 9 and 10 with Figure 11, we see that the poorly poised distilled water used in this last series of tests has its redox potential affected to a greater extent by the water/sediment reaction than do the other solutions.

\section{Solution Composition of the Batch Experiments}

Table 9 lists the composition of the solutions obtained at various times during several of the batch tests. The composition of the lixiviant after four hours of purging (Test IC) did not change significantly except for a decrease in the concentrations of calcium and carbonate (as reflected in the alkalinity values). This response is due to the precipitation of calcite as the $\mathrm{pH}$ of the solution rises (from 8.3 to 8.9) during purging of $\mathrm{CO}_{2}$ and oxygen. The precipitation of calcite adds hydrogen to the solutions, thereby lowering the $\mathrm{pH}$ to its value of 8.3 after four hours of purging. Note also that the concentration of $\mathrm{Mn}$ decreases by $50 \%$ and the $\mathrm{Sr}$ concentration decreases a few tenths of a part per million. This may be caused by the scavenging of these elements from solution by calcite as it precipitates.

The compositions of the solutions from Tests $2 \mathrm{C}$ and $3 \mathrm{C}$ indicate the interactions that occur when the purged lixiviant is mixed with reduced sediments and ore-zone sediments, respectively. For both of these tests calcium concentration increased over the first few hours and then either remained stable or decreased to an intermediate value. On the other hand, carbonate concentrations decreased by $50 \%$ throughout both tests. The increase in Ca concentration may be due to desorption of Ca from surfaces of the sediment inineral in response to the introduction of the Na-rich lixiviant. Sodium in the ground water from the ore zone has a mean concentration of $484 \mathrm{ppm}$ (see Table 8 ), whereas the lixiviant has a concentration of approximately $1000 \mathrm{ppm}$. The mixing of lixiviant with sediment would result in ion exchange of $\mathrm{Na}$ for $\mathrm{Ca}$ on the mineral surfaces, increasing the Ca concentration in solution and causing calcite to precipitate and the carbonate concentration to decrease below its initial value. There is too much variation in the concentration values for $\mathrm{Na}$ for us to determine if its concentration decreases significantly.

The composition of the solutions used in the distilled-water/sediment tests ( $4 \mathrm{~B}$ and $4 \mathrm{C}$ ) did not change significantly over the duration of the tests, except for $\mathrm{Ca}$ in Test $4 \mathrm{C}$. Calcium concentration in Test $4 \mathrm{C}$ probably increases as a result of mixing with residual pore water and desorption from mineral surfaces. The calcium concentration in Test $4 B$ did not increase appreciably 
TABLE 9. Composition of Batch Solutions (units are ppm unless otherwise noted)

\begin{tabular}{|c|c|c|c|c|c|c|c|c|c|c|c|c|c|c|}
\hline \multirow{2}{*}{$\begin{array}{c}\text { ID } \\
\text { Effluent (pore volumes) }\end{array}$} & \multicolumn{2}{|c|}{$\begin{array}{l}\text { Batch IC } \\
\text { LixIviant WI thout } \\
\text { Sodiment }\end{array}$} & \multicolumn{3}{|c|}{$\begin{array}{l}\text { Botch } 2 C \\
\text { LixIvlant with } \\
\text { Reduced Sodimont }\end{array}$} & \multicolumn{3}{|c|}{$\begin{array}{l}\frac{\text { Oatch } 39}{\text { LIx|v|ant with }} \\
\text { Ore Sediment }\end{array}$} & \multicolumn{3}{|c|}{$\begin{array}{l}\text { Batch } 48 \\
\text { Oistlilled Water with } \\
\text { Reduced Sediment }\end{array}$} & \multicolumn{3}{|c|}{$\begin{array}{l}\text { Batch \&C } \\
\text { Distillad Water } \\
\text { WIth Ore Sediment }\end{array}$} \\
\hline & $|n|+|a|$ & $4 h$ & $\ln i t \operatorname{lal}$ & $5 \mathrm{~h}$ & $23 n$ & Initial & $9 \mathrm{~h}$ & $28 \mathrm{~h}$ & Initial & $4 n$ & $24 \mathrm{~h}$ & $\ln |+| a \mid$ & $5.5 \mathrm{~h}$ & $45 h$ \\
\hline $\mathrm{pH}$ & 8.3 & 8.3 & 8.3 & ๑.2 2 & 8.6 & 9.2 & 8.5 & 8.6 & 9.3 & 9.2 & 9.2 & 8.6 & 8.6 & 8.7 \\
\hline En (mv) & +292 & +190 & +98 & +160 & +199 & +173 & +245 & +158 & +139 & +94 & +102 & +16 & +100 & -104 \\
\hline Alkollnity $\left(\mathrm{mg} / \mathrm{CO}_{3}\right)$ & 181 & 140 & 108 & 76 & 55 & 108 & 52 & 55 & 19 & 23 & 19 & 5.2 & 6.5 & 6.5 \\
\hline cos & 200 & 155 & 155 & 213 & 210 & 285 & 445 & 345 & 25 & 13 & 24 & 8.3 & 160 & 170 \\
\hline $\mathbf{H g}$ & 88 & 90 & 87 & 88 & 88 & 94 & 105 & 94 & 8 & 4 & 7 & 14.5 & 25 & 27 \\
\hline Na & 1145 & 1200 & 1225 & 1190 & 1220 & 1050 & 1225 & 1050 & 140 & 150 & 130 & 100 & 120 & 130 \\
\hline K & 33 & 34 & 35 & 40 & 42 & 33 & 36 & 35 & 13 & 8 & 12 & 5.8 & B & 12 \\
\hline CI & 1125 & 1125 & 1313 & 1156 & 1094 & 1030 & 1344 & 1094 & 45 & 45 & 45 & 34 & 42 & 47 \\
\hline $\mathrm{SO}_{4}$ & 1400 & 1433 & 1700 & 1700 & 1767 & 1567 & 2500 & 2033 & 280 & 250 & 280 & 4.5 & 7.5 & 8.0 \\
\hline Fo 100 & $<0.05$ & $<0.05$ & $<0.05$ & $<0.05$ & $<0.05$ & 0.04 & 0.08 & 0.04 & 0.009 & 0.068 & 0.012 & $<0.005$ & 0.016 & $<0.005$ \\
\hline$M$ & $<0.05$ & $<0.05$ & 0.094 & 0.055 & $<0.050$ & ND & No & ND & 0.13 & $<0.050$ & 0.052 & N.D. & N.D. & N.D. \\
\hline $\mathrm{PO}_{4}$ & $<0.1$ & $<0.1$ & $<0.1$ & $<0.1$ & $<0.1$ & $<0.1$ & $<0.1$ & $<0.1$ & $<0.1$ & $<0.1$ & $<0.1$ & $<0.3$ & $<0.3$ & $<0.3$ \\
\hline 4 & 0.21 & 0.26 & 0.25 & 0.25 & 0.27 & 0.19 & 0.19 & 0.2 & 0.034 & 0.030 & 0.032 & 0.021 & 0.042 & 0.026 \\
\hline Cd & $<0.004$ & $<0.004$ & $<0.004$ & $<0.004$ & $<0.004$ & 0.014 & 0.014 & 0.016 & $<0.004$ & $<0.004$ & $<0.004$ & $<0.004$ & $<0.004$ & $<0.004$ \\
\hline sr & 3.4 & 5.0 & 4.9 & 6.2 & 6.2 & 5.5 & 6.8 & 5.7 & 0.6 & 0.3 & 0.6 & 1.11 & 1.99 & 2.23 \\
\hline Ba & 0.02 & 0.03 & 0.03 & 0.05 & 0.03 & No & 0.03 & 0.03 & 0.02 & 0.10 & 0.03 & 0.011 & 0.07 & 0.021 \\
\hline m & 0.08 & 0.04 & 0.06 & 0.07 & 0.05 & 0.4 & 0.2 & 0.1 & 0.007 & 0.032 & 0.011 & 0.16 & 0.14 & 0.065 \\
\hline $\mathrm{Cr}$ & $<0.02$ & $<0.02$ & $<0.02$ & $<0.02$ & $<0.02$ & $<0.02$ & $<0.02$ & $<0.02$ & $<0.02$ & $<0.02$ & $<0.02$ & $<0.02$ & $<0.02$ & $<0.02$ \\
\hline$\omega_{0}$ & $<0.01$ & $<0.01$ & $<0.01$ & $<0.01$ & $<0.01$ & $(0.02)$ & $(0.02)$ & $(0.02)$ & $<0.01$ & $<0.01$ & $<0.01$ & $<0.01$ & $<0.01$ & $<0.01$ \\
\hline NI & $<0.02$ & $<0.02$ & $<0.02$ & $<0.02$ & $<0.02$ & $<0.02$ & $<0.02$ & $<0.02$ & $<0.02$ & $<0.02$ & $<0.02$ & $<0.02$ & $<0.02$ & $<0.02$ \\
\hline Cu M & $<0.030$ & $<0.0<0$ & $<0.030$ & $<0.030$ & $<0.030$ & $<0.030$ & $<0.030$ & $<0.030$ & $<0.030$ & $<0.030$ & $<0.030$ & N.O. & N.D. & N.D. \\
\hline $\mathrm{Zn}$ & 0.2 & 0.05 & 0.10 & $<0.02$ & $<0, .02$ & $<0.02$ & $<0.02$ & 0.05 & $<0.02$ & 0.78 & $<0.02$ & $<0.02$ & $<0.02$ & $<0.02$ \\
\hline Pb & $<0.020$ & $<0.020$ & $<0,020$ & $<0.020$ & $<0.020$ & $<0.020$ & $<0.020$ & $<0.020$ & $<0.033$ & $<0.020$ & $<0.020$ & $<0.06$ & $<0.06$ & $<0.06$ \\
\hline $\mathrm{H}_{4} \mathrm{SIO}_{4}$ & 47 & 45 & 30 & 28 & 25 & 29 & 12 & 20 & 27 & 22 & 17 & 0.93 & 2.8 & 8.0 \\
\hline As $M$ & $<0.010$ & $<0.010$ & $<0.010$ & $<0.010$ & $<0.010$ & $<0.010$ & $<0.010$ & $<0.010$ & $<0.010$ & $<0.010$ & $<0.010$ & N.D. & N.D. & N.D. \\
\hline U & 55 & - & 53 & 47 & 36 & -55 & 54 & $37^{\circ}$ & 0.22 & 0.04 & 0.03 & 0.08 & 0.096 & 0.059 \\
\hline$v$ & $<0.020$ & $<0.020$ & $<0.020$ & $<0.020$ & $<0.020$ & $<0.020$ & $<0.020$ & $<0.020$ & $<0.020$ & $<0.020$ & $<0,020$ & N.D. & N.D. & N.D. \\
\hline So $M$ & $<0.015$ & $<0.010$ & $<0.010$ & $<0.010$ & $<0.015$ & ND & NO & NO & $<0.010$ & $<0.010$ & $<0.010$ & N.D. & N.D. & N.O. \\
\hline
\end{tabular}


because the $\mathrm{pH}$ of the solution in this test is high (greater than 9) and calcite precipitation would limit Ca concentration to a relatively low value at this $\mathrm{pH}$. The high sulfate values in Test $4 \mathrm{~B}$ reflect the presence of soluble gypsum in the reduced sediment.

In summary, the one- and two-day batch experiments showed that the sediments can affect the redox potential and dissolved oxygen content of the solutions they are in contact with, but a vapor phase with as little as $100 \mathrm{ppm}$ oxygen will modify this effect. This fact is important in designing experiments to simulate conditions in a deep aquifer that has very low amounts of oxygen in the ground water. The $\mathrm{pH}$ of our solutions was affected by purging and appeared to be buffered by the mineral calcite. Ion exchange can be expected between solutions and sediments if the solution composition changes. The exchange of sorbed species may aid or hinder restoration, depending on the restoration criteria. The lessons learned from the batch tests were used in the design of the column experiments and as an aid in interpreting the results of the column tests.

\section{COLUMN EXPERIMENTS}

As described in the section on experimental methods, the column experiments were carried out in two sets. The first set of experiments was conducted in August 1982 and used radiotraced lixiviant as the influent solution to the columns. We did not attempt to minimize contact of the equipment with oxygen in the open atmosphere. During the November-December 1982 experiment we used untraced lixiviant and ground water as the influent solutions and placed the entire experimental setup in a controlled-atmosphere (argon) chamber to preclude as much as possible the influence of atmospheric oxygen on the system. The columns in both sets of experiments were filled with sediment from the orezone aquifer downgradient from the uranium deposit. The results of each set of experiments are described separately below, followed by a discussion of the chemical processes that took place during the experiments and which may be of importance to ground-water restoration.

Series 1: Conducted with Equipment Exposed to Atmospheric Oxygen and with Radiotraced Lixiviant as the Influent Solution

The chemical characterization of selected aliquots of the effluent from the four columns run during August 1982 may be found in Appendix B, Table B.1. The median cumulative volume of effluent for each aliquot has been calculated and converted to pore volumes. The median cumulative volume is the sum of the total volume collected before the aliquot of interest, plus one-half the volume of the aliquot of interest. A pore volume is the product of the total column volume and the porosity, and represents the void space within the packed column.

The effluent chemistry from all four columns of this experiment follows the same pattern and, in general, reaches steady concentrations for most constituents after the first pore volume has exited the column. For the constituents $\mathrm{Li}, \mathrm{NO}_{3}, \mathrm{Na}, \mathrm{Cl}$, Se, $\mathrm{Br}, \mathrm{Mo}, \mathrm{Cd}, \mathrm{La}$, and $\mathrm{HCO}_{3}$, steady values are reached after the first pore volume at concentrations similar to that of the lixiviant. 
The concentrations of $\mathrm{Al}, \mathrm{P}, \mathrm{Cr}, \mathrm{Fe}, \mathrm{Co}, \mathrm{Ni}, \mathrm{Cu}, \mathrm{As}$, and $\mathrm{Pb}$ remain near or below their respective detection limits (Appendix A, Table A.3) throughout the experiment. After two to five pore volumes of effluent have passed through the column, the concentrations of $\mathrm{B}, \mathrm{SO}_{4}, \mathrm{Ca}, \mathrm{Zn}, \mathrm{Ba}$, and $\mathrm{U}$ reach steady-state values. Magnesium, potassium, and strontium show a decrease in concentration throughout the experiment, and silicon shows a small increase. Manganese shows a distinct increase in the first pore volume, then decreases to its detection limit until approximately 10 pore volumes, at which point it slightly increases until the experiments stop at about 13 pore volumes. Antimony values are somewhat erratic, probably because of spectral interferences on its emission line during ICP analysis.

The composition of the residual pore water in the sediments (approximately that of Well 912, Table 7) is quite different from that of the influent lixiviant; consequently, the composition of the first pore volume of effluent changes drastically as the pore water is flushed out. The analysis of the first solution collected (median pore volume $=0.3$ ) shows significant increases in $\mathrm{Na}, \mathrm{Mg}, \mathrm{SO}_{4}, \mathrm{~K}, \mathrm{Mn}, \mathrm{Ca}$, and $\mathrm{Sr}$ over either the lixiviant or entrained ground water (assuming a composition similar to Well 912). Conversely, $\mathrm{HCO}_{3}$, Si, and $B$ are significantly lower in the first aliquot of effluent than either the lixiviant or ground water. The chloride concentration of the first aliquot of effluent is intermediate between the ground water $(417 \mathrm{mg} / \mathrm{L}$ ) and the lixiviant. $(1045 \mathrm{mg} / \mathrm{L})$. Assuming that chloride is a non-interacting constituent, the observed mean value of chloride concentration for the first aliquot of effluent from the four columns, $670 \mathrm{mg} / \mathrm{L}$, represents a mixture of $60 \%$ ground water and $40 \%$ lixiviant. Uranium concentrations in the first aliquots of effluent are $20 \%, 36 \%, 1 \%$, and $7 \%$ of the lixiviant's concentration for the four columns. Except for the second column results, the uranium appears to be definitely removed from the first aliquot of effluent as opposed to simple dilution during mixing of lixiviant with ground water of low $U$ content. Further, the uranium content of the effluents does not rise to the value in the lixiviant until 3.4, 4,3 , and 2.5 pore volumes of effluent have been collected from columns 1 through 4 , respectively.

The radiotracer data show that, over the time frame of the column experiments, ${ }^{73} \mathrm{As},{ }^{109} \mathrm{Cd}, 210 \mathrm{~Pb},{ }^{5} \mathrm{Cr}$, ${ }^{59} \mathrm{Fe}, 54 \mathrm{Mn}$, and $228 \mathrm{Ra}$ do not migrate through the sediments. In fact, less than $1 \%$ of the amount injected of any of these nuclides is found in column effluents. On the other hand, $20 \%$ of the introduced ${ }^{75} \mathrm{Se}$ travels through the sediments with the water.

We determined the profile of the radionuclides retained in the sediment by dissecting the columns at the end of the experiment and counting sections of the columns. Table 10 lists the profiles and Table 11 shows the percentage of radionuclides retained in the column that had traveled beyond the designated distances in the column. Because Se was the only tracer that traveled through the entire column length, the data in Table 11 represent the percentage of injected tracer that traveled beyond the set distances. Less than $1 \%$ of the iron moves farther than $2.5 \mathrm{~cm}$ in the column, whereas $5.2 \%$ of the $\mathrm{cd}, 20 \%$ of the $\mathrm{Cr}, 26.8 \%$ of the $\mathrm{Ra}, 36.9 \%$ of the $\mathrm{Pb}, 40.2 \%$ of the $\mathrm{Mn}, 54.2 \%$ of the As, and $72.9 \%$ of the Se moves farther than $2.5 \mathrm{~cm}$. The percentages of radionuclides traveling farther than $5 \mathrm{~cm}$ is $0.55 \%$ for $\mathrm{Fe}, 4.1 \%$ for $\mathrm{Cd}, 4.6 \%$ for $\mathrm{Cr}, 7.1 \%$ for $\mathrm{Ra}, 20.2 \%$ for $\mathrm{Pb}, 30.5 \%$ for $\mathrm{Mn}, 33.7 \%$ for $\mathrm{As}$, and $58.4 \%$ for Se. 
TABLE 10. Radionuclide Content of Sediments After Lixiviant Flush

(in $\mathrm{pCj} / \mathrm{g}$ except for $\mathrm{Ra}$, which is in $\mathrm{cpm} / \mathrm{g}$ )

\begin{tabular}{|c|c|c|c|c|c|c|c|c|}
\hline \multirow[b]{2}{*}{ Depth $(\mathrm{cm})$} & \multicolumn{3}{|c|}{ Column 1} & \multicolumn{2}{|c|}{ Column 2} & \multicolumn{2}{|c|}{ Column 3} & \multirow{2}{*}{$\frac{\text { Column } 4}{228 \mathrm{Ra}}$} \\
\hline & ${ }^{73} \mathrm{As}$ & ${ }^{109} \mathrm{Cd}$ & ${ }^{210} \mathrm{Pd}$ & ${ }^{51} \mathrm{Cr}$ & ${ }^{75} \mathrm{Se}$ & ${ }^{54} \mathrm{Mn}$ & ${ }^{59} \mathrm{Fe}$ & \\
\hline 0.0 to 2.5 & $\overline{7.80 \times 10^{4}}$ & $9.69 \times 10^{2}$ & $1.64 \times 10^{3}$ & $7.35 \times 10^{3}$ & $2.59 \times 10^{3}$ & $6.73 \times 10^{3}$ & $1.80 \times 10^{4}$ & $2.39 \times 10^{2}$ \\
\hline 2.5 to 3.8 & $3.58 \times 10^{4}$ & $2.10 \times 10^{1}$ & $3.02 \times 10^{2}$ & $1.57 \times 10^{3}$ & $1.39 \times 10^{3}$ & $1.17 \times 10^{3}$ & $1.01 \times 10^{3}$ & $9.39 \times 10^{1}$ \\
\hline 3.8 T0 5.1 & $3.35 \times 10^{4}$ & ND $(a)$ & $5.60 \times 10^{2(b)}$ & $1.25 \times 10^{3}$ & $1.38 \times 10^{3}$ & $1.01 \times 10^{3}$ & $5.00 \times 10^{1}$ & $1.28 \times 10^{1}$ \\
\hline 5.1 to 14.0 & $1.58 \times 10^{4}$ & NO & $1.50 \times 10^{2}$ & $1.22 \times 10^{2}$ & $8.33 \times 10^{2}$ & $9.44 \times 10^{2}$ & $2.23 \times 10^{1}$ & 2.4 \\
\hline 14.0 to 20.3 & $7.87 \times 10^{2}$ & $1.69 \times 10^{1}$ & ND & $5.97 \times 10^{2}$ & $2.43 \times 10^{1}$ & 1.79 & 1.4 & \\
\hline 20.3 to 26.3 & $5.83 \times 10^{1}$ & ND & NO & $5.00 \times 10^{2}$ & 2.38 & 0.6 & 3.7 & \\
\hline
\end{tabular}

TABLE 11. Percentage of Retained Nuclide that Travels Beyond Selected Depths

\begin{tabular}{|c|c|c|c|c|c|c|c|c|}
\hline Beyond $(\mathrm{cm})$ & $73_{\mathrm{As}}$ & ${ }^{109} \mathrm{Cd}$ & $210 \mathrm{pb}$ & ${ }^{51} \mathrm{Cr}$ & ${ }^{75} \mathrm{Se}$ & ${ }^{54} \mathrm{Mn}$ & ${ }^{59} \mathrm{Fe}$ & ${ }^{228} \mathrm{Ra}$ \\
\hline 2.5 & $\overline{54.1}$ & 5.2 & 36.9 & $\overline{20.0}$ & $\overline{72.9}$ & $\overline{40.2}$ & 0.9 & 26.8 \\
\hline 3.8 & 43.6 & 4.1 & 31.0 & 11.5 & 65.6 & 35.0 & 0.6 & 9.0 \\
\hline 5.1 & 33.7 & 4.1 & 20.2 & 4.6 & 58.4 & 30.5 & 0.5 & 7.1 \\
\hline 14.0 & 1.2 & 4.1 & 0.0 & 0.0 & 27.9 & 1.0 & 0.3 & 4.5 \\
\hline 20.3 & 0.08 & 0.0 & 0.0 & 0.0 & 12.3 & 0.5 & 0.0 & 2.7 \\
\hline
\end{tabular}


The tracer data for iron agree qualitatively with the total iron analyses of the lixiviants and column effluents. Detectable iron (greater than $0.05 \mathrm{mg} / \mathrm{L}$ ) is not found in these solutions. The lixiviant and column effluent data for cadmium, chromium, lead, and arsenic show concentrations near their respective detection limits and no distinct trends are observed. The effluent manganese data show relatively high concentrations in the first pore volume, but this effect is not reflected in the tracer concentration. Ninety-nine percent of the influent manganese tracer is retained in the first $5 \mathrm{~cm}$ of the $26-\mathrm{cm}$ core. The divergence between tracer results and effluent concentrations of manganese may be due to localized redox reactions between the water and sediment that occur as the lixiviant flows through the core. The selenium tracer data do not follow the trend noted for total selenium in the effluent; this effect may also be due to variable redox conditions in the core.

Thus, we cannot definitely state that the radiotracers are following the patterns observed for the total element; nor can we say that the radionuclides are acting as a good 'tracer' for the element. Because of this uncertainty and of the added complications of handling spiked solutions, we decided not to use radiotracers during the second set of column experiments.

Series 2: Conducted in a Controlled-Atmosphere (Argon) Chamber with Untraced Lixiviant and Ground Water as the Influent Solutions

The batch experiments had shown that solutions in contact with an atmosphere of relatively low oxygen content responded to the oxygen that was present and raised the Eh of the solution above that which would be attained in a closed water/sediment system. The ore-zone aquifer is not in contact with an atmosphere of even low oxygen content; consequently, to best simulate this low oxygen environment in the lab we decided to move the entire column experimental equipment into a controlled-atmosphere chamber and to measure as many parameters of the solution that we could before the effluent solution contacted the atmosphere of the chamber. To this end the in-line Eh and pH electrode flow cells described in the methodology section were designed and installed in the effluent line from the lixiviant/sediment columns. In addition, flow cells were installed on the influent line of one of the columns.

In this experiment, we ran four columns filled with sediment from the reduced zone of the ore zone aquifer. Columns 1 and 2 had a pore volume of approximately $150 \mathrm{~cm}^{3}$. Ground water collected from Well 912 at the Benavides Site was used as the influent solution for Column 1. We ran Column 1 to determine the chemical response of a water/sediment system to flushing with oxygenated ground water and to provide baseline data for comparisons with the columns for which lixiviant was the influent solutign. Columns 2, 3, and 4 had a pore volume of approximately 150,300 , and $600 \mathrm{~cm}^{3}$, respectively. Five pore volumes of lixiviant were pumped through Column 2 and three pore volumes passed through Column 4. After 3 pore volumes of effluent had been collected from Column 3, the influent solution was changed from lixiviant to ground water from Well 912 to simulate the response of the sediments to passage of the lixiviant and re-equilibrtion with the native ground water. Approximately 150 samples of effluent were collected from these four columns. The complete analyses are contained in Appendix $B$ and the data are summarized below. 
The analysis of the influent solution for Column 1 (analysis $6 \mathrm{GH}-2$, Appendix B, Table B.2) at the beginning of the experiment compares favorably with the original analysis of Well 912 water (see Table 7). The water is a sodium bicarbonate-chloride type with moderate amounts of calcium, potassium, and sulfate. Chemical data from the first pore volume of effluent provide information on the composition of the residual pore water in the sediments. The concentrations of $\mathrm{Ca}, \mathrm{Mg}, \mathrm{Na}, \mathrm{K}$, and $\mathrm{SO}_{4}$ are all significantly higher in the first effluents collected from Column 1; the values decrease toward the influent concentrations as the amount of solution pumped through the column increases. This behavior is demonstrated in Figure 12 for $\mathrm{Ca}$ and $\mathrm{SO}_{4}$. The peak in $\mathrm{Ca}$ and $\mathrm{SO}_{4}$ concentrations at 2.5 pore volumes is probably due to late flushing of a pocket of residual pore water from the column. The carbonate concentration of the effluents starts out much lower than the influent value, but increases, approaching the influent concentration, after 1.5 pore volumes have passed through the column. Silica concentration (as $\mathrm{H}_{4} \mathrm{SiO}_{4}$ ) is approximately $g \mathrm{ppm}$ higher in the influent solution than in any of the effluents. within our analytical precision, the chloride concentration remains constant throughout the experiment. The trend in effluent composition observed during this column experiment suggests that before this experiment began, chemical reactions had occurred between the sediment and its residual pore water, probably in response to temporary exposure of the core to the open atmosphere during sampling. As will be shown from the results of the other columns, this did not completely destroy the reducing capacity of these sediments.

Lixiviant from well 666 at Benavides was pumped through Columns 2, 3, and 4. The initial effluents from Column 2 (analyses 2-1 through 2-4, Appendix B, Table B.2) are similar to the first effluents from Column 1, as expected. The analyses reinforce the observation that the composition of the pore water has changed during storage. The concentrations of most nonredox-sensitive major constituents of the solution ( $\mathrm{Ca}, \mathrm{Mg}, \mathrm{Na}, \mathrm{Cl}$, and $\mathrm{Si}$ ) approach their respective influent concentrations as the pore water is flushed out. Although carbonate alkalinity increases in response to the addition of the carbonate-rich lixiviant, its concentration remains approximately $100 \mathrm{ppm}$ (as $\mathrm{CO}_{3}$ ) below the influent value throughout the experiment. The potassium concentration, on the other hand, is higher by 20 to $30 \mathrm{ppm}$ than that of the influent lixiviant. Sulfate is expected to be affected by the redox reaction that might occur between the oxidizing lixiviant and the reduced sediment (containing pyrite, $\mathrm{FeS}_{2}$ ). The sulfate concentration in the lixiviant (from four separate analyses) averages $1500 \mathrm{ppm}$, which is slightly below (by 100 to $320 \mathrm{ppm}$ ) the amount measured in the effluents collected during the latter part of the experiment. This suggests that sulfate is being produced in the column, possibly by oxidation of pyrite by the lixiviant.

How uranium in the influent solution responds to contact with the sediment is, of course, of primary interest in these column tests. Uranium is the only redox-sensitive constituent in the pregnant lixiviant available from the Benavides Site that is generally thought of as a contaminant from mining operations. Arsenic, molybdenum, and selenium in the lixiviant are either below or close to detection limits (near or below the MCL levels) and would not be considered hazardous at this site. In general, uranium can be considered as an 


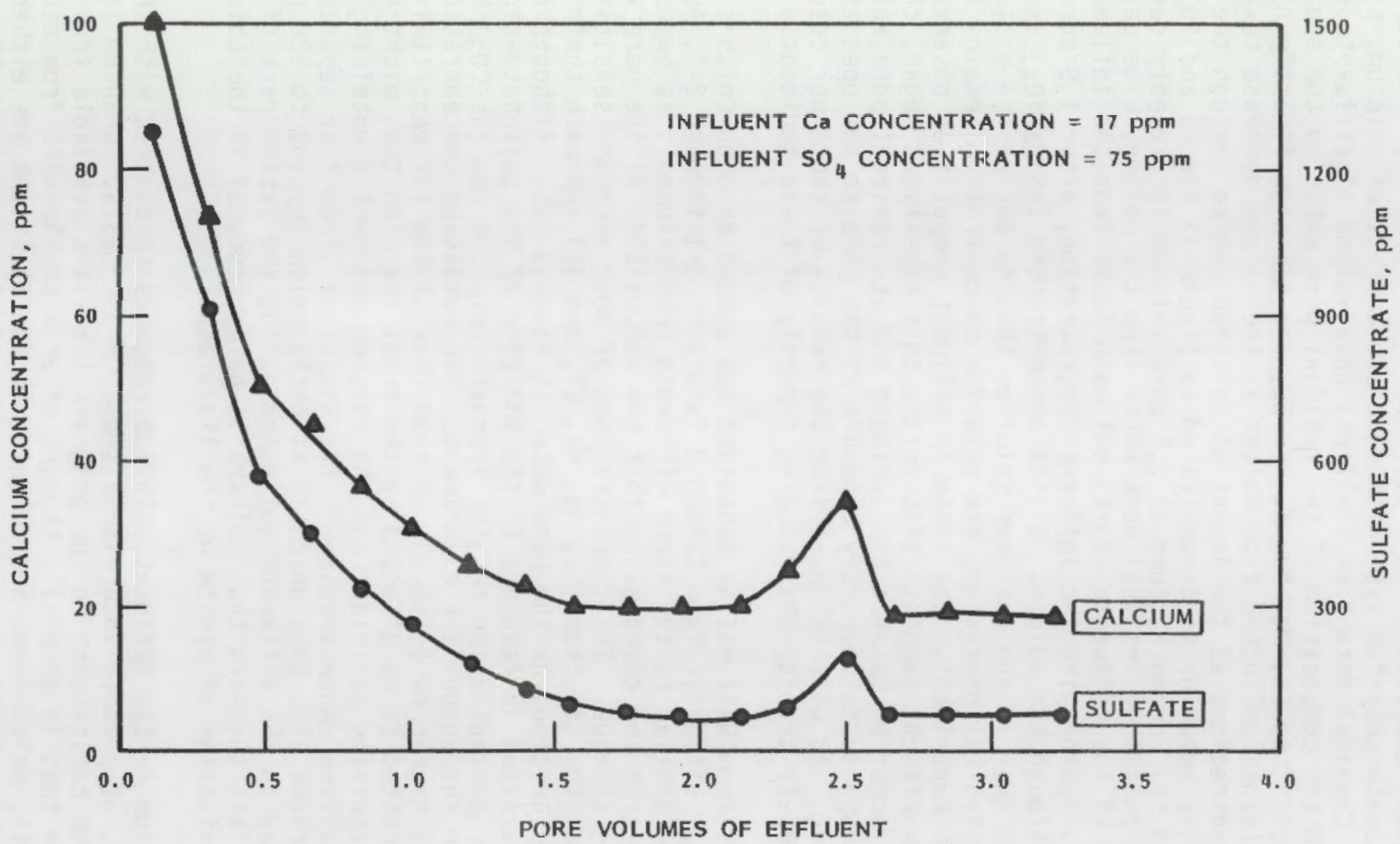

FIGURE 12. Concentration of Calcium and Sulfate in Effluents from Column 1 
analogue for these other redox-sensitive elements and it is present in such high concentrations in the lixiviant that its response to the presence of reducing sediment can be readily measured.

For Column 2, the initial effluents collected contained very low uranium as would be expected, considering its low concentration in the ground water retained in the pores of the sediment. As the ratio of lixiviant to residual pore water exiting the column increases, the amount of uranium in solution also increases. However, as shown in Figure 13, the uranium concentration in the effluent never reaches that of the influent; in fact, after less than two pore volumes of effluent are collected (one pore volume of residual pore water plus one of injected lixiviant), the uranium concentration in the effluent begins to decrease and stabilizes around 2 ppm $U$ after 3 pore volumes are eluted. Figure 13 shows a similar response of uranium in Column 3 and a hint of the same response in Column 4 where only 3 pore volumes of effluent had been collected.

The redox potential, Eh, is a measure of the oxidation-reduction state of a system and can be used with the measured concentration of redox-sensitive elements in solution to determine some of the water/sediment interactions that are affecting the solution composition. The initial lixiviant Eh $(+260)$ is similar to the measured value of Eh for unpurged lixiviant in the batch tests. The Eh of the influent lixiviant was measured periodically during the test to see if keeping the solution inside the controlled-atmosphere chamber affects the Eh. Throughout the experiment the lixiviant Eh remained between +250 and $+350 \mathrm{mv}$. The change of the Eh of the effluents during these flowthrough experiments, as measured by in-line electrode cells, is the most dramatic of all the parameters measured. Figure 14 shows the change in Eh versus pore volumes eluted for Columns 2,3 , and 4 . We believe that the large initial drop in Eh from $+200 /+300 \mathrm{mv}$ to $-200 /-300 \mathrm{mv}$ is an artifact of our method, described below, of calibrating the Eh platinum electrode.

We used the quinhydrone technique for electrode calibration. This technique consists of adding quinhydrone to $\mathrm{pH} 4$ and $\mathrm{pH} 7$ buffer solutions and calibrating the platinum electrode with these solutions. The resulting theoretical Ehs of these solutions are +462 and $+285 \mathrm{mv}$, respectively. Compared to conditions in a deep, reducing aquifer, these are very oxidizing Eh values. When the platinum electrode is taken from the well-poised quinhydrone solution and placed in the poorly poised effluent solution from the column, the electrical response of the electrode is non-ideal. Measuring an accurate Eh in the effluent requires that a large volume of effluent contact the electrode before the system can overcome the effect of being calibrated in a highly oxidizing solution. Our tests have shown (see Figure 14) that approximately $300 \mathrm{ml}$ of effluent must contact the electrode before accurate measurements of Eh are possible.

This response of the electrode is also demonstrated by the Column 2 and 3 Eh data during the middle of the test. Before we realized the large effect the calibrating solution had on the Eh electrodes, we decided that the electrodes should be recalibrated to ensure that they were functioning properly. We 


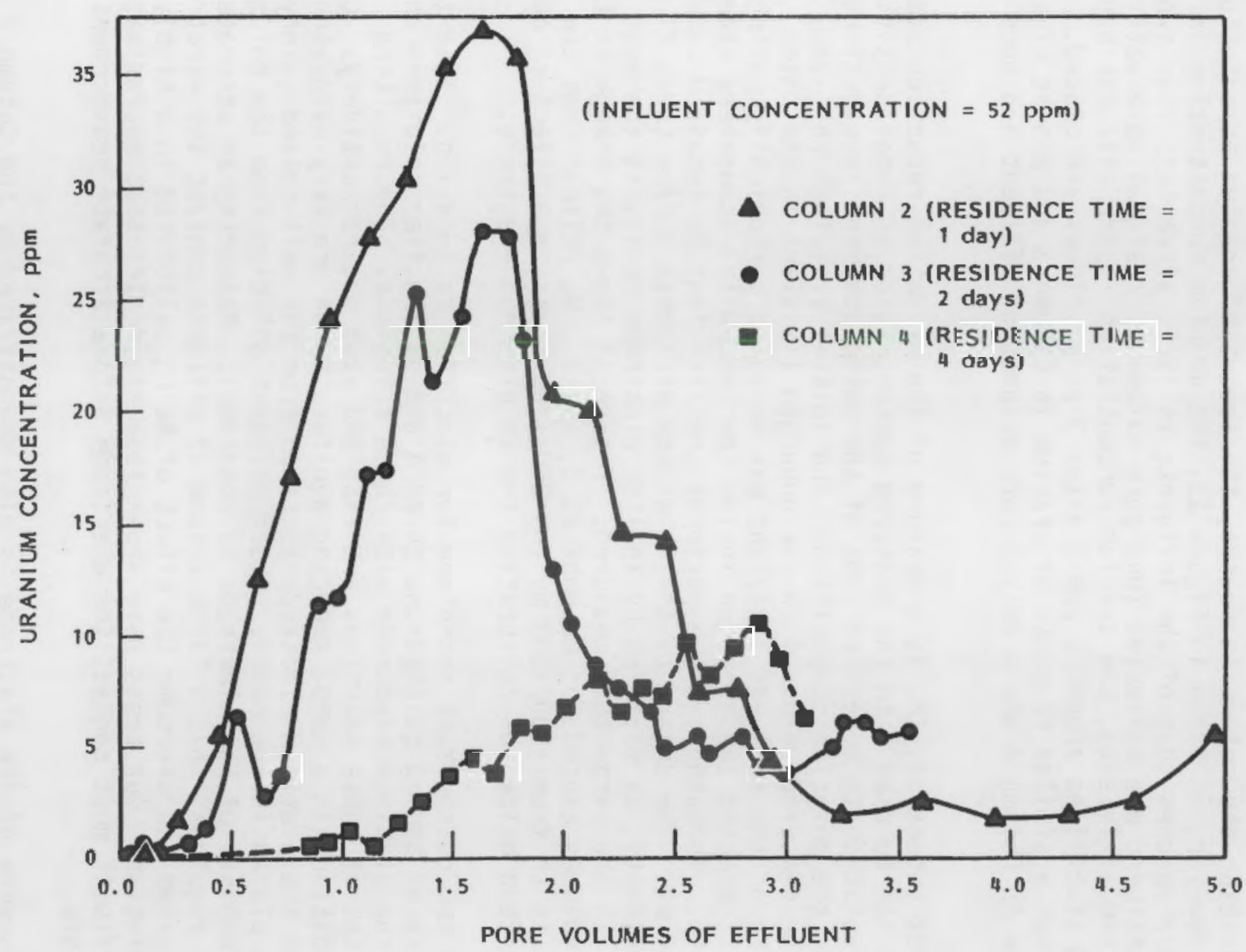

FIGURE 13. Concentration of Uranium in Effluents from Columns 2, 3 , and 4 


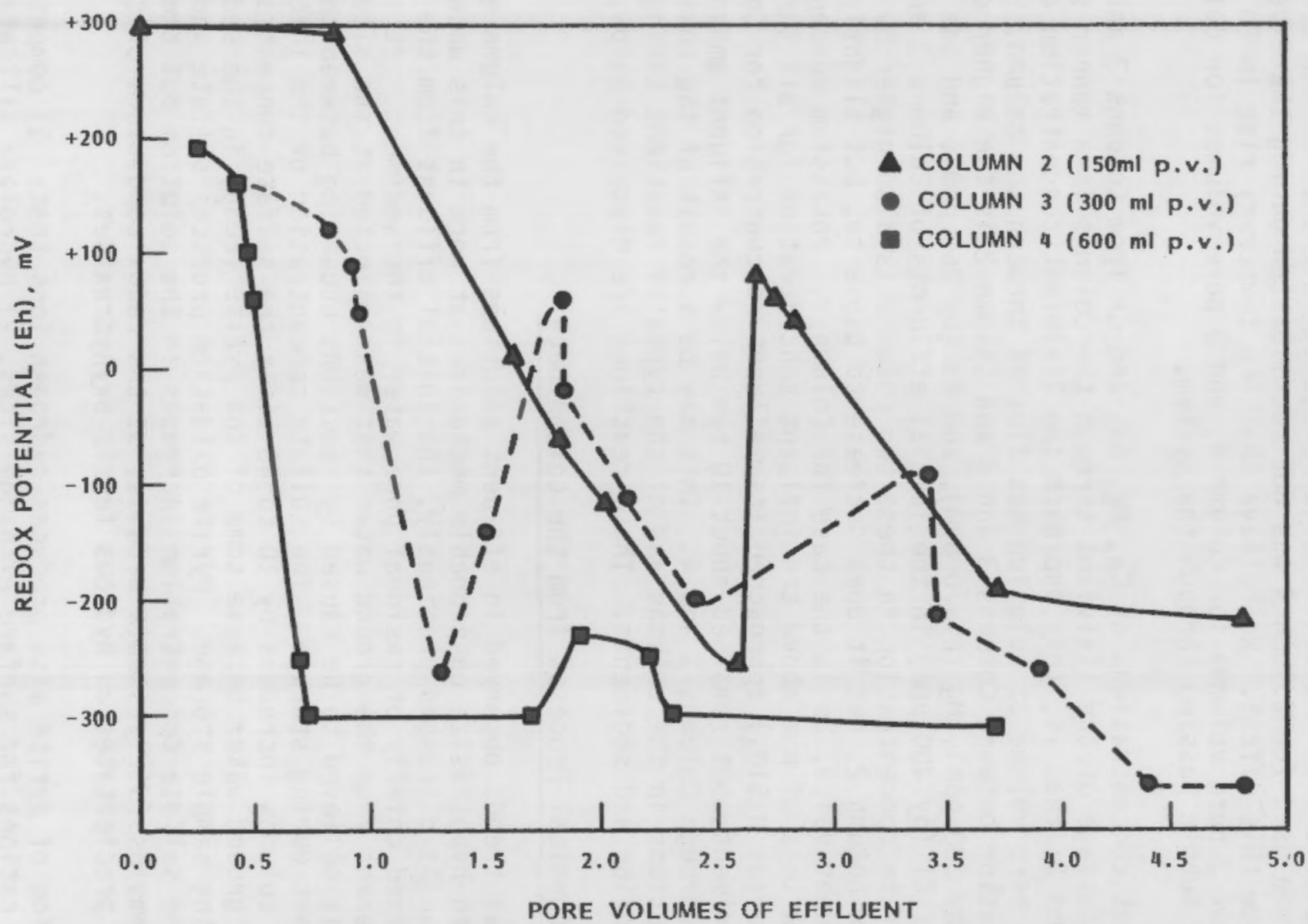

FIGURE 14. Effluent Eh Readings for Columns 2, 3, and 4 
removed the Column 2 and 3 Eh electrodes from their in-line holders and placed them in the pH 4 and 7 quinhydrone solutions. They both read close to the expected (highly oxidizing) values. The electrodes were then replaced in their holders and flow was resumed in the columns. The effect of this procedure on the Eh measurements for the next 200 to $300 \mathrm{ml}$ of effluent for Columns 2 and 3 can be seen in the large spikes in the data (Figure 14). In a sense, the surface of the electrodes were poisoned by the oxidizing quinhydrone solutions and required a large volume of the effluent to re-equilibrate them at the correct Eh. The electrode used for Column 4 was not recalibrated during the experiment and does not show this effect. We believe that the temporary rise in Eh observed at about 2 pore volumes for Column 4 , and 3 pore volumes for Column 3 , was caused by a bubble passing through the system.

The effluent concentrations of $\mathrm{Ca}, \mathrm{Mg}, \mathrm{Na}$, and $\mathrm{Cl}$ from Columns 3 and 4 respond to the passage of the lixiviant through the columns in a manner similar to that of Column 2; that is, they approach the lixiviant concentration after approximately a pore volume of solution has flushed through the column. An unexpected variation between Columns 3 and 4 and Column 2 is the higher concentration of $\mathrm{Ca}$ (by $200 \mathrm{ppm}$ ), $\mathrm{Mg}$ (by $70 \mathrm{ppm}$ ), and $\mathrm{Na}$ (by $260 \mathrm{ppm}$ ), and the 10 wer concentration of $\mathrm{Cl}$ (by $400 \mathrm{ppm}$ ) in the initial effluents of Columns 3 and 4 . The initial sulfate concentration in these two columns is also higher by $1500 \mathrm{ppm}$ than in Column 2, but it does decrease to close to, but slightly above, the influent value, as is the case for Column 2. Potassium concentration stays a few tens of ppm above the influent concentration for all three columns. Silica (as $\mathrm{H}_{4} \mathrm{SiO}_{4}$ ) approached its influent concentration for column 2 during the experiment, but remained about $10 \mathrm{ppm}$ below the influent amount during pumping through Columns 3 and 4 . This may be a result of the residence time of the solutions in the columns and of the types of reactions taking place between the solution and sediments. These reactions are discussed below.

\section{Information on Chemical Processs from the Column Data}

The chemical trends observed in effluent solutions from the column experiments allow us to hypothesize on probable mechanisms at work in this water/ sediment system. As discussed previously, the initial effluent from the columns is composed chiefly of residual pore water in the sediment. It is distinctly different from the ground water that was collected at the site and this variation is believed to be caused by reactions occurring between the pore water and sediment during storage. The sulfate concentration of the initial effluent of all columns increases by 10 to 40 times the sulfate concentration of the measured ground water because some of the pyrite $\left(\mathrm{FeS}_{2}\right)$ in the sediment is oxidized during sample storage. Pyrite oxidation produces sulfate and ferric iron. The sulfate concentration increases in the solution but the iron concentration remains fairly stable because, at the redox conditions of these solutions, iron precipitates as hydrous ferric oxyhydroxides.

The oxidation of pyrite also produces hydrogen ions that: 1) compete with other dissolved cations for surface exchange sites, 2) hydrolyze silicate minerals, and 3) dissolve carbonates. These reactions all tend to increase the amount of $\mathrm{Ca}, \mathrm{Mg}, \mathrm{Sr}, \mathrm{Na}$, and $\mathrm{K}$ in the solution and this effect is observed in 
the initial effluents. The only constituent of the initial effluent solutions that shows a lower concentration when compared to the ground-water composition is carbonate. Expressed as carbonate $\left(\mathrm{CO}_{3}\right)$ alkalinity, the concentration of this constituent decreased in half during the storage period of the core in response to the increasing concentration of $\mathrm{Ca}$ (and probably $\mathrm{Mg}$ and $\mathrm{Sr}$ to some extent) and the resulting precipitation of calcite $\left(\mathrm{CaCO}_{3}\right)$.

After the residual pore water is flushed from the cores, the effect of the lixiviant/sediment interaction is observed in the composition of the effluent solutions. Pyrite is stable in the low redox state of the system, established by the reducing sediment and shown by the measured Eh values of the effluent. Because pyrite is stable, sulfate is not produced and the dissolution and ion exchange reactions accompanying an increase in hydrogen concentration do not occur. As a result, the concentrations of $\mathrm{Ca}, \mathrm{Mg}, \mathrm{Sr}$, $\mathrm{Na}, \mathrm{K}$, and $\mathrm{SO}_{4}$ decrease and approach the influent concentration as effluent volume increases. The concentration of most of these constituents in the effluent does not quite decrease to their respective concentrations in the influent lixiviant. A difference in concentration between the influent and effluent solutions is to be expected if the oxidizing lixiviant is being reduced by the sediment and some of the reaction products are being produced. At the low Ehs measured for the effluent, sulfide would be the expected sulfur specie rather than sulfate. Apparently the rate of sulfate reduction is not adequate under the conditions of the column experiments to remove an appreciable amount of the influent sulfate.

The carbonate concentration of the effluent increases as the effect of the lixiviant increases and the calcium concentration decreases. The solution is attempting to Inaintain equilibrium with calcite. Mineral equilibria may also play a role in determining the concentration of silica in the effluent. The lixiviant is oversaturated with respect to the silica minerals chalcedony, cristobalite, and quartz. With a proper substrate and sufficient time to precipitate, this oversaturation (at least with respect to chalcedony and cristobalite) probably would not persist. The first effluents from Columns 1 through 4 are all in equilibrium or are undersaturated with respect to chalcedony and cristobalite. As the effect of the lixiviant is seen in Column 2, the silica concentration (as represented by $\mathrm{H}_{4} \mathrm{SiO}_{4}$ ) rises to the lixiviant value (oversaturated with respect to cristobalite) and remains close to it. However, in the case of Column 3 and especially in Column 4, the effluent silica concentration does not reach the influent value but, instead, remains close to what would be expected for equilibrium with cristobalite. The difference in the responses of the three columns is due to the residence time of the solution in each and the corresponding amount of time for equilibration between the solution and sediment. In column 2 the solution moves through the column at an average of a pore volume per day, whereas in Column 3 the residence time is two days, and in Column 4 it is four days. This indicates the amount of time the lixiviant must spend in contact with this aquifer sediment to come to equilibrium with typical silica minerals.

The chemical interaction of uranium with the sediment is of primary interest for its own sake and because of what it might tell us about other redox-sensitive elements. As was shown in Figure 13, uranium concentration in 
solutions from the second set of column tests is definitely affected by reactions between the lixiviant and sediment for at least the first 3 to 5 pore volumes of effluent. Appendix B, Table B.l, which contains data for the first set of column experiments, shows that the uranium concentration of the effluent reached the influent lixiviant value of $54 \mathrm{ppm}$ after approximately 4 pore volumes of lixiviant had been injected. We believe that oxygen contamination of the sediment that occurred while the first set of columns were run affected the reducing capacity of the sediment, thereby allowing U(VI) in the influent solution to pass through the column without reduction to U(IV) and precipitation. The second set of column experiments were run in a controlled atmosphere chamber and the low oxygen content of the chamber minimized oxygen contamination of the columns.

In the second set of column experiments a definite maximum in uranium concentration occurs at approximately 1.5 pore volumes of effluent for Columns 2 and 3, and may or may not occur for Column 4. Following the peak in uranium concentration of the effluents, the value decreases and appears to stabilize between 2 and $6 \mathrm{ppm}$ uranium. The stabilization of uranium concentration in the low ppm range is probably due to solubility control on uranium exerted by some solid phase. If a solid is precipitating in response to being oversaturated it will limit the concentration of uranium in the solution to a value in equilibrium with itself. No matter how much dissolved uranium is present in the influent solution, if the precipitation of the solid proceeds at a fast enough rate compared with the flow rate of the solution, it will keep uranium concentration at a fixed level. Calculations of the saturation index of amorphous $\mathrm{UO}_{2}$ for the effluent solutions collected after 2 pore volumes for the three columns show that the solutions approach equilibrium with this solid or a phase with similar thermodynamic properties (Figure 15).

On the other hand, amorphous $\mathrm{UO}_{2}$ is oversaturated in the peak area of uranium concentration between 1 and 2 pore volumes of effluent. To calculate the saturation index (S.I.) of amorphous $\mathrm{UO}_{2}$ we assumed that the Eh of these solutions is $-200 \mathrm{mv}$ and that sufficient time had occurred for the reduction of $U(V I)$ in the influent solution (Eh $=+300 \mathrm{mv}$ ) to the U(IV) state. However, if uranium is predominantly in the +6 state, its concentration ( $52 \mathrm{ppm})$ would be too low for a uranium compound to precipitate, as evidenced by the uniform uranium concentration of the lixiviant that had been stored a number of months. Oversaturation of the solution with respect to amorphous $\mathrm{UO}_{2}$ does not appear to be realistic considering the apparent ability of this solid or of one with similar thermodynamic properties to limit uranium concentration in the column solutions. Most likely, the uranium present in the solutions that were eluted at around one pore volume for Columns 2 and 3 is present as U(VI) rather than as U(IV). The establishment of the solubility control on uranium then must hinge on the rate of reduction of U(VI) to U(IV). Two explanations are possible for why this reduction does not occur with the initial lixiviant injected, and consequently why the peak in uranium values exists.

First, the reduction of uranium may be biologically mediated. If this is the case and the bacteria needed the oxygen of the lixiviant in order to grow, then the bacteria would follow a typical growth/death curve, and their optimum 


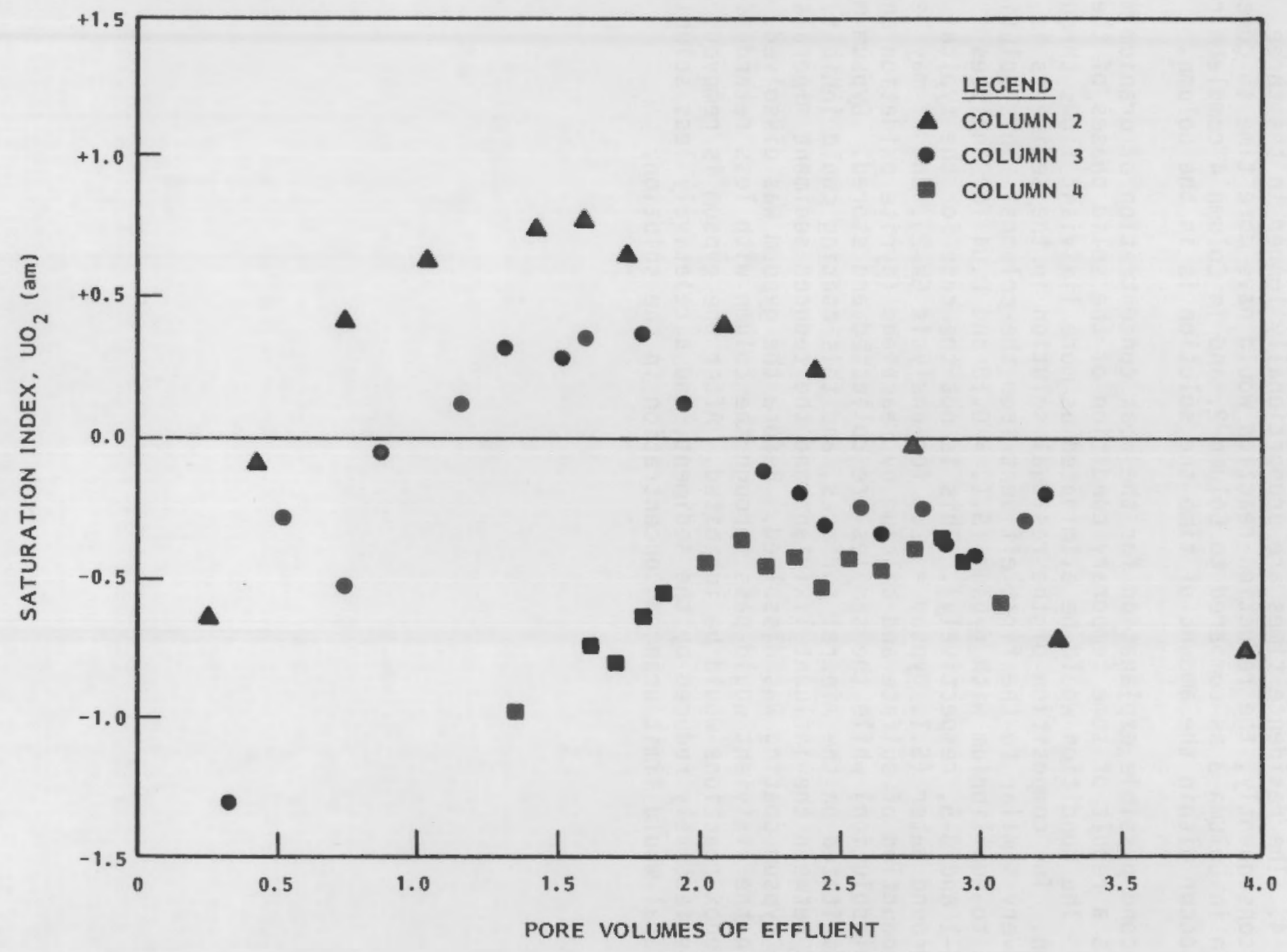

FIGURE 15. Saturation Index (S.I.) of $\mathrm{UO}_{2}(\mathrm{am})$ 
development would trail the arrival of the first lixiviant as effluent from the columns. It would only be after the bacteria population had grown to an effective level that U(IV) would dominate the uranium speciation and thereby promote the formation of $\mathrm{UU}_{2}(\mathrm{am})$. The growth rate effect would also explain the variations in the peak height for Columns 2 and 3, and the possible lack of a peak in Column 4. The residence times are proportionally longer in the three columns; consequent1y, the reduction reaction would have more time to come to completion in Column 3 as compared to Column 2, and in Column 4 complete reduction may occur within the amount of time the solution is in the column.

A second possible explanation for the peak concentration of uranium may be that it is a result of some temporary condition of the solid phases of the sediment. The condition would be eliminated as more lixiviant flows through the column. The composition of the residual solution in the sediments is probably very similar to the first effluent from the columns. This solution was close to equilibrium with gypsum (S.I. $=0.10$ and 0.04 for analyses numbers 3-1 and 3-5, respectively). This is not the case for the typical aquifer ground water (S.I. gypsum $=-2.3$ for analysis $\mathrm{GW}-2$ ), and it may be due to the production of sulfate and calcium by reactions (pyrite oxidation and calcite dissolution) while the samples are collected and stored. Gypsum may have precipitated on the mineral surfaces, and this coating could inhibit reactions between the influent lixiviant and the reduced sediment minerals until the gypsum coating was dissolved. Before the gypsum was dissolved, the uranium in the lixiviant would pass through the column with less retardation because redox reactions would be inhibited. After the gypsum is removed, U(VI) would be effectively reduced by the sediment, and a relatively less soluble U(IV) mineral would limit uranium concentration in the solution. 
EXPERIMENTAL STUDIES APPLIED TO EXCURSION DETECTION

AND AQUIFER RESTORATION

The batch and column experiments described in this report were designed to simulate the interaction of lixiviant from an in-situ leach uranium mine with the sediments surrounding the leach field. Lixiviant may contact sediment from the aquifer during an excursion and during restoration of a site. Excursions occur when control of the lixiviant is lost and the solution moves out of the leach zone into the surrounding aquifer. Restoration of an aquifer involves all the remedial actions taken to return the chemical quality of the ground water in the aquifer to the level it had before mining. Natural restoration, whereby chemical reactions between the lixiviant and sediment improve the quality of the solution, can reduce the overall cost of restoration and the end product is a water/sediment system that is stable (i.e., in equilibrium. Information on excursion detection and natural restoration as it applies to mining operations can be obtained from the results of the experiments described in this report.

\section{EXCURSION DETECTION}

In the section on the ground-water analyses for the Benavides Site, we suggested guidelines for excursion indicators based on the composition of average ground water in the ore-zone aquifer and on the composition of the lixiviant. We stated that a nonreactive anion and the total dissolved solids (TDS) level would make good excursion indicators if their concentrations differed appreciably between the lixiviant and the ground water. The migration rate of cations in the ground water may be retarded by ion exchange and mineral precipitation; therefore, cations would not be a good first choice for an indicator. The actual effect on the transport of cations and anions in solution due to contact with the sediment can be estimated from the column effluent data. Table 12 lists the mean concentrations and standard deviations of dissolved constituents in the ground water, lixiviant, and selected effluents from Column 3 of the second set of column experiments. The effluents from Column 3 were selected to represent the case where uranium concentration was high (approximately $25 \mathrm{ppm}$ ), uranium concentration had leveled out at about $5 \mathrm{ppm}$, and after 2 pore volumes of Well 912 ground water had flushed out the lixiviant.

Table 13 contains the ratios of the solution components in Table 12 for the lixiviant and effluents versus the ground water. As can be seen from the two tables, the $\mathrm{Ca}, \mathrm{Mg}, \mathrm{Na}, \mathrm{K}$, and $\mathrm{Sr}$ concentrations in solution remain high compared to ground water as lixiviant passes through the sediment. Chloride and carbonate concentrations are above ground-water values but not appreciably so. Sulfate has a very high ratio of effluent to ground-water concentration and does not appear to be inhibited by passage through the column. Uranium shows the biggest divergence between effluent and ground-water concentrations but the experiments show that uranium is definitely influenced by passage through the column. The ratio of total dissolved solids in lixiviant and effluent compared to the ground water is almost identical. 
TABLE 12. Mean Composition and Standard Deviation of Ground Water and Lixiviant from Benavides Leach Facility and Selected Column Effluents

\begin{tabular}{|c|c|c|c|c|c|c|c|c|c|c|c|}
\hline & \multicolumn{2}{|c|}{ Ground Water (a) } & \multicolumn{2}{|c|}{ Lixiviant (b) } & High & \multicolumn{2}{|c|}{ Column 3} & nium (d) & \multicolumn{2}{|c|}{$\begin{array}{l}\text { Ground-Water } \\
\text { Flush(e) }\end{array}$} \\
\hline & & $\overline{\bar{x}(\mathrm{ppm})}$ & $\sigma$ & $\overline{\bar{x}}(\mathrm{ppm})$ & $\sigma$ & $\bar{x}$ & $\sigma$ & $\bar{x}$ & $\sigma$ & $\bar{x}$ & 0 \\
\hline & $\mathrm{pH}$ & 8.6 & 0.1 & 8.0 & 0.06 & 7.8 & 0 & 7.7 & 0 & 7.8 & 0 \\
\hline & $\operatorname{En}(\mathrm{mV})$ & -38 & 71 & +260 & 82 & N.D. & $=$ & N.D. & & N.D. & \\
\hline & $\mathrm{Ca}$ & 17.2 & 5.0 & 231 & 13 & 265 & 13 & 239 & 4.3 & 25 & 4 \\
\hline & $\mathrm{Mg}$ & 6.1 & 1.4 & 86 & 0.5 & 98 & 3.4 & 98 & 2.9 & 12 & 1.3 \\
\hline & $\mathrm{Na}$ & 445 & 102 & 970 & 35 & 1045 & 64 & 1183 & 22 & 480 & 34 \\
\hline & K & 14 & 2.9 & 34 & 5 & 53 & 7.7 & 60 & 3.9 & 41 & 10 \\
\hline & $\mathrm{Cl}$ & 603 & 178 & 1025 & 24 & 1149 & 30 & 1085 & 39 & 453 & 15 \\
\hline & $\mathrm{SO}_{4}$ & 63 & 14 & 1501 & 113 & 1500 & 27 & 1683 & 64 & 148 & 29 \\
\hline gू & $\mathrm{HCO}_{3}$ & 181 & 40 & 459 & 48 & 237 & 27 & 179 & 18 & 294 & 7.5 \\
\hline & $\mathrm{Fe}_{\text {Total }}$ & 0.017 & 0.012 & $<0.010$ & N.D. & 0.03 & 0.02 & 0.04 & 0.05 & $<0.010$ & N.D. \\
\hline & Al & 0.019 & 0.007 & 0.02 & 0.02 & 0.016 & 0.009 & 0.02 & 0.01 & 0.015 & 0.006 \\
\hline & $\mathrm{Sr}$ & 0.90 & 0.62 & 5.7 & 0.08 & 7.4 & 0.4 & 6.5 & 0.8 & 0.8 & 0.1 \\
\hline & Si & 8.1 & 0.27 & 9.3 & 0.2 & 7.1 & 0.3 & 6.6 & 0.2 & 4.9 & 0.2 \\
\hline & U & 0.10 & 0.06 & 52 & 5.6 & 24.9 & 2.9 & 5.4 & 0.8 & 0.81 & 0.6 \\
\hline & TOS & 1350 & 253 & 4383 & 61 & 4397 & 84 & 4555 & 97 & 1463 & 86 \\
\hline
\end{tabular}

(a) Mean values for Wells 691, 912 and 958 (see Table 7).

(b) Mean values for lixiviant samples no. $L-1, L-2, L-3$, and $L-4$ from Well 666 (Appendix $B$, Table B.2.2).

(c) Mean values for effluents $3-19,3-20,3-22$, and 3-23 (Appendix B, Table B.2.3).

(d) Mean values for effluents $3-34,3-35,3-37$, and 3-38 (Appendix B, Table B.2.3).

(e) Mean values for effluents $3-58,3-59,3-60$, and 3-62 (Appendix B, Table B.2.3).

N.D.-- not determined 
TABLE 13. Ratios of Lixiviant and Selected Column Effluents to Ground Water Composition at the Benavides Leach Facility

\begin{tabular}{|c|c|c|c|c|c|}
\hline $\begin{array}{l}\text { Solution } \\
\text { Component }\end{array}$ & Lixiviant ${ }^{(b)}$ & $\begin{array}{l}\text { Conce } \\
\text { High }\end{array}$ & $\begin{array}{l}\text { entration Ratios: } L \\
\text { Uranium Effiuent }\end{array}$ & $\begin{array}{l}\text { xiviant and Effluent to } \\
\text { Low Uranium Effluent }(\mathrm{d})\end{array}$ & $\frac{\text { round Water }(a)}{\text { Ground-Water Flush }}(\mathrm{e})$ \\
\hline $\mathrm{Ca}$ & 13 & & 15 & 14 & 1.5 \\
\hline $\mathrm{Mg}$ & 14 & & 16 & 16 & 2.0 \\
\hline $\mathrm{Na}$ & 2.2 & & 2.3 & 2.7 & 1.1 \\
\hline K & 2.4 & & 3.8 & 4.3 & 2.9 \\
\hline $\mathrm{Cl}$ & 1.7 & & 1.9 & 1.8 & 0.8 \\
\hline $\mathrm{SO}_{4}$ & 24 & & 24 & 27 & 2.3 \\
\hline $\mathrm{HCO}_{3}$ & 2.5 & & 1.3 & 1.0 & 1.6 \\
\hline $\mathrm{Sr}$ & 6.3 & & 8.2 & 7.2 & 0.9 \\
\hline Si & 1.2 & & 1.1 & 0.8 & 0.6 \\
\hline U & 520 & & 249 & 54 & 8.1 \\
\hline TDS & 3.3 & 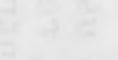 & 3.3 & 3.4 & 1.1 \\
\hline
\end{tabular}

\footnotetext{
(a) Composite of well samples 691,912 and 958 (Table 7).

(b) Composite of lixiviant samples $L-1, L-2, L-3$, and $L-4$ (Appendix B, Table B.2.2).

(c) Composite of effluents $3-19,3-20,3-22$, and 3-23 (Appendix B, Table B.2.3).

(d) Composite of effluents 3-34,3-35,3-37, and 3-38 (Appendix B, Table B.2.3).

(e) Composite of effluents $3-58,3-59,3-60$, and 3-62 (Appendix B, Table B.2.3).
} 
Although the cations $\mathrm{Ca}, \mathrm{Mg}, \mathrm{Na}, \mathrm{K}$, and $\mathrm{Sr}$ show large concentration differences, over the distance the solution must travel from the leach field to a monitor well (30 to 60 meters) their individual concentrations in solution may be changed through ion exchange. In the case of uranium, the column 3 data show that solution movement through a column only $22 \mathrm{~cm}$ long is enough to reduce its concentration from over $50 \mathrm{ppm}$ in the lixiviant to 5 to $10 \mathrm{ppm}$ in most effluents; consequently, uranium would not be a good indicator of an excursion. Of the anions considered, $\mathrm{Cl}$ and $\mathrm{SO}_{4}$ have reasonably larger concentrations in the effluents compared to ground water. Chloride is normally considered to be a good tracer of ground-water flow because it is not retarded by most chemical processes and it may be satisfactory in this case. Sulfate is considered reactive, but for the column experiments run there is no noticeable decrease in sulfate concentration. Possibly, the reduction of sulfate to less highly oxidized sulfur compounds would be slow enough in the typical aquifers where leach mining is used so that sulfate would be a good excursion indicator. The fact that the total dissolved solids level is almost identical for the lixiviant and effluents suggests that it would make a good excursion indicator. The amount of TDS could be easily estimated in the field with a conductivity meter.

\section{NATURAL RESTORATION}

All regulatory agencies require that an active restoration technique be used at in-situ leach sites. The results of recent attempts at restoration for pilot-scale and commercial operations are summarized by Riding and Rosswog (1979) and Buma et al. (1981). They show that some operators have had trouble lowering uranium, molybdenum, arsenic, selenium, sulfate, and ammonium concentrations in the ground water to the required level. Given sufficient time for interaction between the residual lixiviant and the aquifer sediments, the natural system itself will have some capacity for re-establishing pre-mining chemical conditions in the ore zone and for retarding the movement of contaminants in the aquifer. The data in Tables 12 and 13 can be used to evaluate how the sediments downgradient from a leached ore zone might affect the groundwater concentration of contaminants from the mining operation.

Ammonium $\left(\mathrm{NH}_{4}\right)$ was used by the industry as a major component of the lixiviant, until it was realized that ammonium is very difficult to remove from an aquifer once it is introduced. Also, there is a possibility that the nitrogen in ammonium could be oxidized to nitrite and nitrate, which could pose a health problem. Earlier laboratory and modeling studies have dealt with the migration and removal of ammonium in aquifers associated with in-situ mining [Walsh et al. (1979); Garwacka et al. (1979); Yan and Espenscheid (1982)]. The results of these studies and actual attempts at restoration have shown that for a reasonable amount of effort it may be impossible to reduce ammonium level in the ground water to pre-mining values. For this reason the industry has switched from ammonium-based lixiviants to lixiviants in which sodium is the dominant cation. Thus, the experiments designed to investigate natural restoration for this study did not include restoration of ammonium-enriched ground water. 
The redox state of the reduced zone in the aquifer downgradient from the ore deposit is below the theoretical stability boundary between sulfate and sulfide (Drever 1982). However, the ground-water analyses for samples collected from this zone of the aquifer (Tables 7 and 12) show the presence of sulfate at a concentration of approximately $60 \mathrm{ppm}$, whereas sulfide was below its detection limit $(0.02 \mathrm{ppm})$ in all cases. The rate of reduction of sulfate and sulfide is slow unless it is biologically mediated, and the discrepancy between theory and measured concentrations is probably due to this fact. Because sulfate reduction is slow and the solubility of sulfate minerals is high in aquifer conditions, natural restoration is not expected to appreciably lower the sulfate concentration in the ground water until the solution is in contact with the sediment for a long period of time (years). If a particular aquifer has conditions conducive to the growth and perpetuation of sulfatereducing bacteria, then natural restoration may play a role in lowering sulfate concentration by the reduction of sulfate to sulfide and precipitation of less soluble sulfide minerals.

As was shown in Figure 13 and discussed previously, the uranium in the lixiviant is affected by contact with reduced sediments typical of those that the lixiviant would encounter as it moved out of the ore zone into the surrounding aquifer. Throughout the column tests, depicted in Figure 13, the lixiviant that is pumped into the columns contains a uranium concentration of $52 \mathrm{ppm}$, and yet the uranium concentration in the effluent averages $5 \mathrm{ppm}$, after an initial peaking of uranium concentration for the two shorter columns. Movement of the lixiviant through as little as $11 \mathrm{~cm}$ (Column 2) of sediment effectively reduces the uranium concentration in solution by an order of magnitude. The sediment's capacity to remove uranium appears to be quite high, as shown by the stability of uranium concentration at near the 5-ppm level as many pore volumes of lixiviant flow through the column. A uranium concentration of $5 \mathrm{ppm}$ is high for most ground waters because of the generally small amount of uranium in sediments. Therefore, restoration of uranium to this level would probably not be acceptable to most regulatory agencies; however, continued equilibration of the solution and sediment probably would further lower the concentration of uranium in the ground water. Ultimately, the uranium concentration would probably reach the original concentration value if equilibrium is attained between the ground water and the uranium minerals that occur in the roll front.

The concentrations of arsenic, molybdenum, and selenium in the lixiviant and sediments used in this study are very low and would not be considered a health hazard at this mine site, except possibly selenium, which occurs at twice the concentration of its drinking water standard for some of the initial effluents from the column experiments. However, these elements are groundwater contaminants at some mines and the potential effect of natural restoration on their concentration in solution should be estimated. Because these elements are redox sensitive and typically occur in roll-front uranium deposits, their normal mineral distribution associated with an ore zone can be used as a guide to estimate the effect of natural restoration processes on their mobility in solution. Harshmann (1974) has compiled the available information on the distribution of trace elements upgradient and downgradient from roll-front deposits in Texas and Wyoming. Figures 16 and 17 show this 


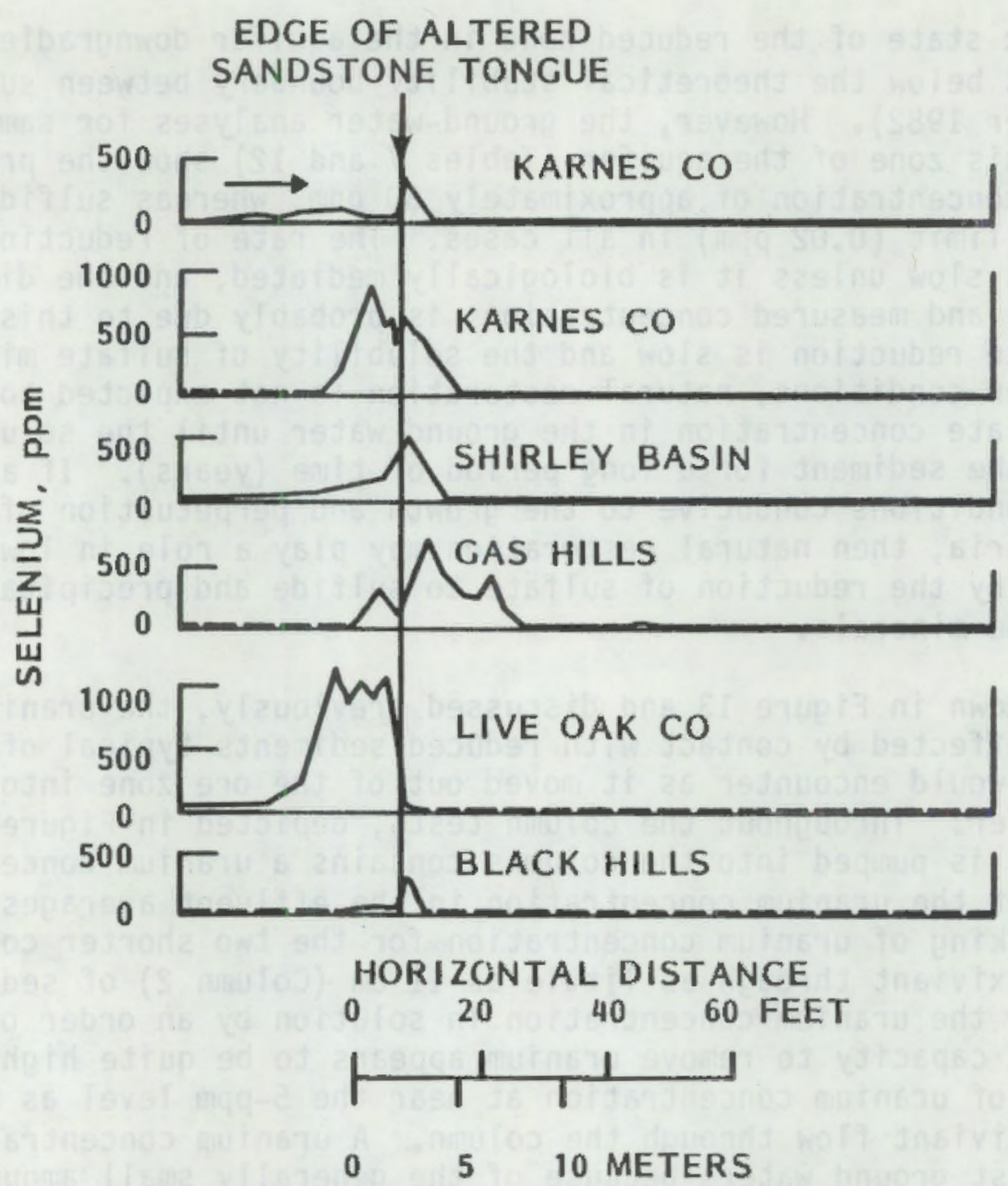

FIGURE 16. Distribution of Selenium Around a Roll-Front Uranium Deposit (After Harshmann 1974)

distribution and suggest that selenium and arsenic will be effectively removed from solution upgradient and downgradient, respectively, from the point at which uranium is redeposited. Figure 18 shows that if molybdenum concentrations are elevated through leach mining of uranium, this element may move a relatively long distance (tens of meters) past the location where uranium is deposited, but ultimately molybdenum will be deposited in response to the reducing conditions of the aquifer. The concentration will stabilize at a level in equilibrium with a molybdenum solid phase.

A final note on natural restoration can be obtained from the response of Column 3 in the second set of flow-through column tests. After three pore volumes of lixiviant were pumped through this column, the influent solution was changed from lixiviant to ground water typical of that found in the reduced 


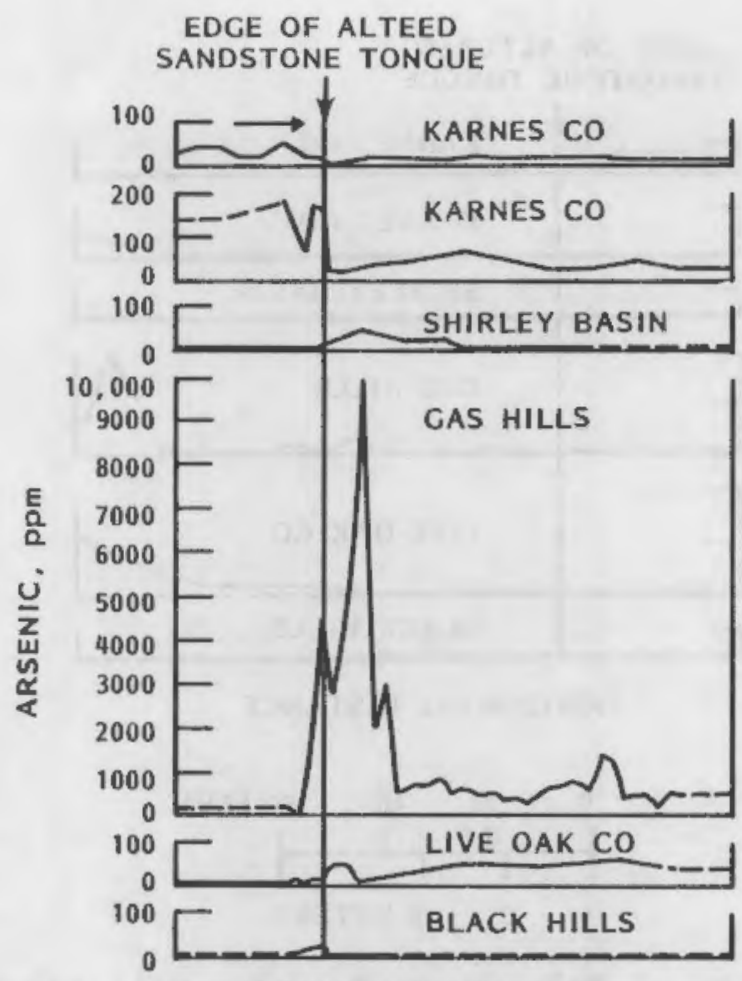

HORIZONTAL DISTANCE

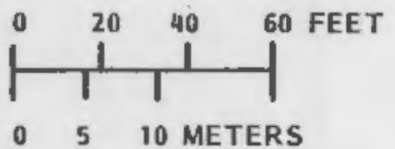

FIGURE 17. Distribution of Arsenic Around a Roll-Front Uranium Deposit (After Harshmann 1974)

region of the aquifer (Well 912). Soon after this switch in solution type the permeability of the sediment changed drastically, as shown by a decrease in effluent flow rate. Before the change in influent solution, the column had been discharging $6 \mathrm{ml}$ of solution per hour, whereas after the change the flow rate dropped to approximately $3 \mathrm{ml}$ per hour. A change in permeability is a fairly common phenomenon experienced during injection of solutions into oil fields to enhance production (Jones 1964; Mungan 1965). In many cases the change in permeability is attributed to dispersion or swelling of clays in the sediments in response to changing solution composition. If this is the case for a uranium ore-zone aquifer following restoration, the ground water moving through the aquifer may be effectively shielded from the leached zone because of that zone's reduced permeability. Most of the ground water would flow around the leached ore zone and not be influenced by it. Additional work needs to be done in this area to determine how effective this process might be and to identify its actual effect on long-term water quality. 

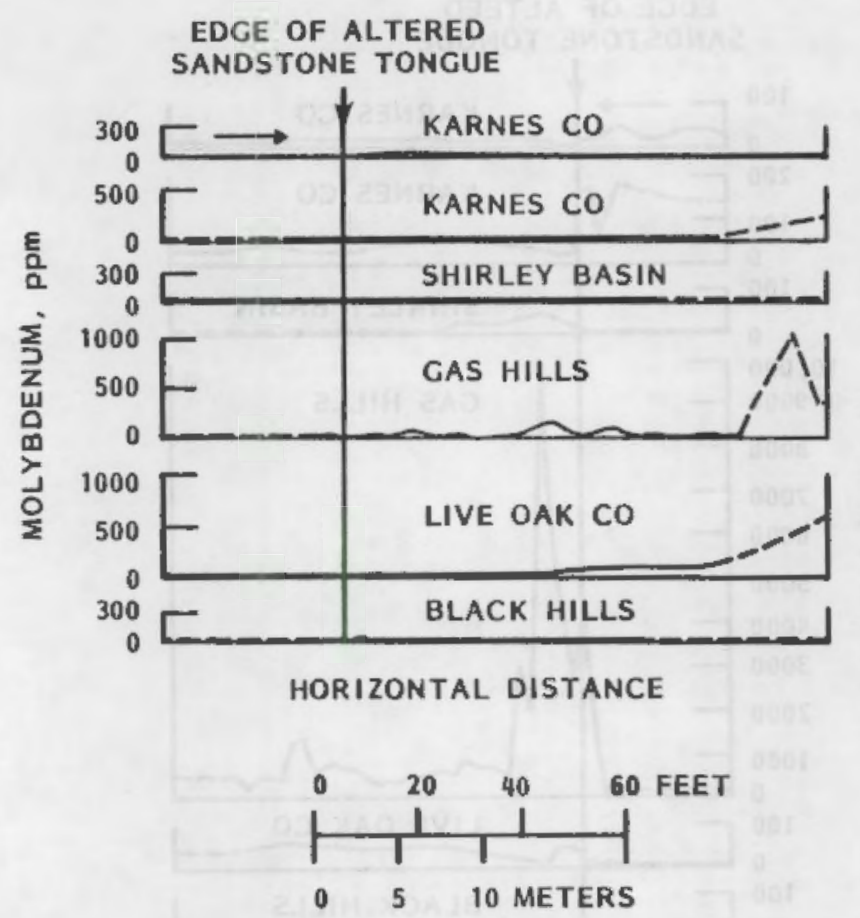

FIGURE 18. Distribution of Molybdenum Around a Roll-Front Uranium Deposit (After Harshmann 1974) 


\section{REFERENCES}

Baas-Becking, L. G. M., I. R. Kaplan, and D. Moore. 1960. "Limits of the Natural Environment in Terms of $\mathrm{pH}$ and Oxidation-Reduction Potentials." J. Geol. $68(3): 243-284$.

Bal1, J. W., E. A. Jenne and M. W. Cantrel1. 1981. "WATEQ3: A Geochemical Model with Uranium Added." Open-File Report 81-1183. U.S. Geological Survey, Denver, Colorado.

Buma, G., et al. 1981. Analysis of Ground Water Criteria and Recent Restoration Attempts After In Situ Uranium Leaching. Contract Report No. J0295019. Final Report to U.S. Department of Interior Bureau of Mines, Washington, D. C.

Crecelius, E. A. 1978. "Modification of the Arsenic Speciation Technique Using Hydride Generation." Anal. Chem. 50(6):826-827.

Drever, J. I. 1982. The Geochemistry of Natural Waters. Prentice-Hall, Inc., Englewood Cliffs, New Jersey.

EPA. 1979. Methods for Chemical Analysis of Water and Wastes. EPA-600 4-79-020, Environmental Monitoring and Support Laboratory, office of Research and Development, U.S. Environmental Protection Agency, Cincinnati, Ohio.

Forbeck, C. C. 1973. Some Studies on the Detection and Determination of Mercury, Arsenic and Antimony in Gas Discharges. Ph.D. Thesis, University of Southern Florida.

Gall oway, W. E. 1977. Catahoula Formation of the Texas Coastal Plain: Depositional Systems, Composition, Structural Development, Ground-Water Flow History, and Uranium Distribution. Report of Investigations No. 87, Bureau of Economic Geology, The University of Texas at Austin, Texas.

Galloway, W. E., and W. R. Kaiser. 1980. Catahoula Formation of the Texas Coastal Plain: Origin, Geochemical Evolution, and Characteristics of Uranium Deposits. Report of Investigations No, 100, Bureau of Economic Geology, The University of Texas at Austin, Texas.

Garwacka, K., et al. 1979. Investigation of the Fate of Ammonia from In Situ Uranium Solution Mining. Technical Report EHE 79-01, Bureau of Engineering Research, University of Texas at Austin, Texas.

Ghosh, M. M., J. T. D'Connor and R. S. Engelbrecht. 1967. "Bathophenanthroline Method for the Determination of Ferrous Iron." J. Am. Wat. Wks. Assoc. 59:897-905. 
Granger, H. C., and C. G. Warren. 1974. "Zoning in the Altered Tongue Associated with Roll-Type Uranium Deposits." In Proceedings from the Symposium on the Formation of Uranium Ore Deposits, IAEA-SM-183, pp. 185-200, International Atomic Energy Agency, Vienna, Austria.

Harshmann, E. N. 1974. "Distribution of Elements in Some Roll-Type Uranium Deposits". In Proceedings from the Symposium on the Formation of Uranium Ore Deposits, IAEA-SM-183, Pp. 169-183.

Jenne, E. A. 1981. Geochemical Modeling: A Review. PNL-3574, Pacific Northwest Laboratory, Richland, Washington.

Jones, Jr., F. 0. 1964. "Influence of Chemical Composition of Water on Clay Blocking of Permeability." J. Petro. Tech. pp. 441-446.

Koppelman, M. H., and A. G. Dillard. 1980. "Adsorption of $\mathrm{Cr}\left(\mathrm{NH}_{3}\right) 6_{6}^{3+}$ and $\mathrm{Cr}(\mathrm{en}) 3_{3}^{3+}$ on Clay Minerals and the Characterization of Chromium by $\mathrm{X}$-ray Photoelectron Spectroscopy." Clays and Clay Minerals 28:211-216.

Lee, G. F., and W. Stumm. 1960. "Determination of Ferrous Iron in the Presence of Ferric Iron with Bathophenanthroline." J. Am. Wat. Wks. Assoc. 52:1567-1574.

McIntyre, N. S., and D. G. Zetaruk. 1977. "X-ray Photoelectron Spectroscopic Studies of Iron 0xides." Anal. Chem. 49:521-1529.

Mungan, N. 1965. "Permeability Reduction Through Changes in $\mathrm{pH}$ and Salinity." J. Petro. Tech. pp. 1449-1453.

Nordstrom, D. K. 1979. "A Comparison of Computerized Chemical Models for Equilibrium Calculations in Aqueous Systems". In Chemical Modeling in Aqueous Systems, ed. E. A. Jenne, pp. 815-835, Ame r. Chem. Soc. Sym. Series 93, Washington, D.C.

Potter II, R. W., M. A. Clynne, J. M. Thompson, et al. 1979. "Chemical Monitoring of the In-Situ Leaching of a South Texas Uranium Orebody." OpenFile Report 79-1144, U.S. Geological Survey, Denver, Colorado.

Riding, J. R., and F. J. Rosswog. 1979. Restoration of Ground Water Quality After In Situ Uranium Leaching. Final Report to U.S. Department of Interior, Bureau of Mines, Contract No. J0275028, Washington, D. C.

Rothrock, R. A. 1981. A Statistical Methodology for Assay of Ground-Water Quality in Uranium Solution Mines. Preprint No. 81-365, Soc. Mining Eng. AIME, LittTeton, Colorado.

Sato, M. 1960. "Oxidation of Sulfide Ore Bodies, 1. Geochemical Environments in Terms of Eh and pH." Ec. Geol. 55:928-961.

URI. 1979. Application and Technical Report: Benavides In-Situ Uranium Leach Project. Uranium Resources, Inc., Richardson, Texas. 
Walsh, M. P. 1979. "A Model for Predicting the Restoration of an Ammonium Migration from In-Situ Mine Sites." South Texas Uranium Seminar, Corpus Christi, Texas, September 10-13, 1978.

Westall, J. C., J. L. Zachary and F. M. M. Morel. 1976. "MINEQL, A Computer Program for the Calculation of Chemical Equilibrium Composition of Aqueous Systems." Tech. Note 18, Dept. Civil Eng., Massachusett.s Institute of Technology, Cambridge, Massachusetts.

Yan, T. Y., and W. F. Espenscheid. 1982. "Removal of Ammonium Ions from Subterranean Formations by Flushing with Lime Saturated Brines." Paper No. 82-02, SME-AIME Annual Meeting, Dallas, Texas. 



\section{APPENDIX A}

COMPARISON OF CHEMICAL DATA AND RECOMMENDATIONS FOR ANALYTICAL TECHNIQUES 


\section{APPENDIX A \\ COMPARISON OF CHEMICAL OATA AND RECOMMENDATIONS FOR ANALYTICAL TECHNIQUES}

The analytical results obtained in the field and later in the lab (within 2 weeks for Lab A, within 4 weeks for Lab B, and within six weeks for Lab C) are shown in Tables A.1 and A.2. In addition, another analysis designated Lab $D$ remeasured some parameters on the radiotraced lixiviant at the conclusion of the column experiments ( 24 weeks after samples were obtained in the field).

The lixiviant, as measured in the field, was supersaturated with dissolved oxygen (23.2 ppm versus $\sim 8$ to $9 \mathrm{ppm}$ for saturation). The excess oxygen was diffused out of the plastic container sometime during the 24 weeks of storage between analyses. The Eh measurements in the field and after 24 weeks of storage were similar but a measurement between 4 and 6 weeks on a separately stored small aliquot read considerably lower (+186 versus $+310 \mathrm{mV})$. Eh measurements were typified as being slowly drifting, suggesting that the system is poorly poised. The downgradient well water sample gave an Eh value of $-85 \mathrm{mV}$ in the field before any contact with air but the Eh rapidly increased after filtration. After one week of storage the well water had a measured Eh of $+130 \mathrm{mV}$. The $\mathrm{pH}$ of the lixiviant rises with storage time from a field value of 6.69 to 6.88 after one week to values between 7.8 and 8.3 after one month to six months. The ground-water sample pH remained stable for the first week at a value of 8.4 .

Over time the lixiviant shows significant drops in bicarbonate content (634 versus $267 \mathrm{ppm}$ ), calcium content ( 320 versus $168 \mathrm{ppm}$ ), Mn content $(0.43$ versus $0.02 \mathrm{ppm}$ ) and $\mathrm{Fe}$ content $(0.12$ versus $<0.05 \mathrm{ppm})$. Conversely, sodium and sulfate concentrations appear to increase (994 versus $1300 \mathrm{ppm}$ and 1270 versus $1435 \mathrm{ppm}$, respectively). These increases probably signify scatter in the analytical results. Sodium analysis by ICP is not very precise $( \pm 30 \%)$ and the original value of 944 appears to be biased low. The four sulfate values reported in Table A.1 show about $20 \%$ scatter. Three different instruments and four different analysts were used to obtain the results and perhaps this level of scatter is common. The decrease in calcium, bicarbonate, manganese, and iron does appear to be real. We suspect that calcite is precipitating from the lixiviant and in fact can see some white precipitate in the bottom of the large container. Furthermore, perhaps the iron and manganese are being coprecipitated with the calcite or are forming hydrous oxides. The precipitation of calcite is also the reason that the pH increases. The other constituents, including trace metals and uranium, appear to be stable in the lixiviant, although most trace metals are present at or below their detection limits.

The downgradient ground water, as typified by analysis of the sample taken from Well 912, shows the water to be dominated by sodium chloride-bicarbonate. No significant changes seem to occur during storage except an increase in Eh and perhaps a slight decrease in carbonate/bicarbonate content. 
The data, which represents the work of three independent labs and instruments and (for several constituents) three different analytical techniques, allow us to evaluate the applicability of the various techniques and to suggest recommended techniques for the various constituents. The ICP results were excellent for either lixiviant or ground-water matrices for the following elements: $\mathrm{Li}, \mathrm{B}, \mathrm{Mg}, \mathrm{Al}, \mathrm{Si}, \mathrm{K}, \mathrm{Ca}, \mathrm{Mn}, \mathrm{Zn}, \mathrm{Sr}, \mathrm{Mo}, \mathrm{Cd}$, and $\mathrm{Ba}$. ICP results for $\mathrm{Na}$ are not precise $( \pm 30 \%)$; not sensitive enough for $\mathrm{P}, \mathrm{Cr}, \mathrm{Fe}, \mathrm{Co}, \mathrm{Ni}$, and $\mathrm{Cu}$; and appear to give unrealistically high values for $\mathrm{Sb}, \mathrm{As}$, and $\mathrm{Pb}$ in high salt solution samples. High values of uranium $(>15 \mathrm{mg} / \ell)$ cause positive interferences on numerous metals, including $\mathrm{Al}, \mathrm{B}, \mathrm{Ca}, \mathrm{Cu}, \mathrm{Fe}, \mathrm{La}, \mathrm{Mg}, \mathrm{Mn}, \mathrm{Mo}$, $\mathrm{Na}$, and $\mathrm{Si}$. For $\mathrm{U}$ concentrations as low as $5 \mathrm{ppm}$, the $\mathrm{Al}, \mathrm{Ca}, \mathrm{Cu}, \mathrm{Fe}, \mathrm{Mg}$, and $\mathrm{Na}$ analyses are biased high. The spectral interferences are not linear, and numerous $U$ standards must be run to bracket the effects on the other elements such that corrections can be made. Alternately, the solutions may be diluted until the uranium concentration is no larger than $1 \mathrm{mg} / \ell$; this procedure, however, raises the detection limits.

Atomic absorption graphite furnace is capable of measuring most metals at low concentrations (below MCL levels) on very small samples. Further, hydride generation is available to extend detection limits on As and Se although larger sample sizes are required ( $50 \mathrm{mls})$.

Ion chromatography has proven quite useful for determining anions, except for bicarbonate/carbonate. The precision for each analyst/instrument is quite good $(< \pm 10 \%)$ and, except for sulfate, analyses by separate analyst/instrument combinations are also precise. Detection limits for common anions depend on the overal total dissolved solids content, but for these in-situ uranium leach samples ( 500 to $>5000 \mathrm{ppm}$ TDS), detection limits of tenths of a part per million are common. The pulsed laser fluorescence technique is much more sensitive than ICP and is favored for analysis of uranium in ground waters. Either method is adequate for the lixiviant.

Table A.3 lists the preferred techniques, practical detection limits and pertinent comments for moderate ionic strength solutions such as the lixiviant and ground water ( 500 to $5000 \mathrm{mg} / \ell$ TDS). 
TABLE A.1. Lixiviant Analyses (Well 666)

Field Results :

$\begin{array}{rl}\mathrm{pH} & 6.69 \\ \mathrm{Eh} & 300 \mathrm{mV} \\ \text { dissolved } \mathrm{O}_{2} & 23.2 \mathrm{ppm} \\ \text { conduct ivity } & 5721 \mu \mathrm{mhos} / \mathrm{cm} \\ \mathrm{s} & <0.02 \mathrm{mg} / \ell \\ \text { NHt } & <0.05 \mathrm{mg} / \ell\end{array}$

Lab Results:

Lab A ran analyses within two weeks of sampling. Lab B ran analyses within four weeks of sampling. Lab $C$ ran analyses within six weeks of sampling. Lab D ran analyses after 24 weeks of sampling

\begin{tabular}{|c|c|c|c|c|}
\hline . & Lab A & Lab B & Lab C & Lab D \\
\hline $\mathrm{pH}$ & 6.88 & --- & 7.87 & 7.8 \\
\hline Eh $(m V)$ & -- & -- & +186 & +310 \\
\hline Dissolved $\mathrm{O}_{2}(\mathrm{ppm})$ & -- & --- & --- & 9.0 \\
\hline Conductivity $(u m h o s / \mathrm{cm})$ & 6352 & -- & 6600 & -- \\
\hline Diss & nstituer & $(\mathrm{mg} / \mathrm{l}$ & & \\
\hline Li & 0.20 & 0.22 & --- & \\
\hline & 1.33 & 1.21 & --- & 1.69 \\
\hline Dissolved organic carbon & 0.45 & --- & -.- & -- \\
\hline $\mathrm{HCO}_{\overline{3}}^{-}$ & 634 & --- & --- & 267 \\
\hline $\mathrm{NO}_{2}{ }^{\mathrm{N}}$ & $<1.0$ & -- & --- & -- \\
\hline $\mathrm{ND}_{3}$ & 0.54 & --- & $<1$. & $<1$. \\
\hline & 0.16 & 0.23 & 0.2 & 0.2 \\
\hline $\mathrm{Na}$ & 944 & 1220 & -- & 1300 \\
\hline $\mathrm{Mg}$ & 91 & 93.7 & -- & 96 \\
\hline Al & $<0.3$ & $<0.8$ & -- & $<0.3$ \\
\hline Si & 8.7 & 10.6 & --- & 11.4 \\
\hline$P$ & 0.09 & 0.31 & --- & $<0.2$ \\
\hline $\begin{array}{l}P_{0} 0_{4} \\
s^{2}\end{array}$ & 80.2 & -.- & 1370 & 1125 \\
\hline $\mathrm{Cl}^{4}$ & 1032 & 1068 & 1039 & $\begin{array}{l}1435 \\
1052\end{array}$ \\
\hline$K(I C P)$ & 29 & 43 & --- & 43.6 \\
\hline (AA) & & 34 & --- & \\
\hline $\mathrm{Ca}$ & 320 & 315 & --- & 168 \\
\hline v & $<0.003$ & --- & $<0.05$ & --- \\
\hline $\mathrm{Cr}$ & -- & 0.42 & $<0.02$ & $<0.02$ \\
\hline Mn & 0.43 & 0.41 & 0.49 & 0.02 \\
\hline $\mathrm{Fe}$ & 0.12 & 0.08 & 0.08 & $<0.05$ \\
\hline Co & $<0.2$ & 0.03 & --. & $<0.1$ \\
\hline
\end{tabular}


TABLE A.1. (contd)

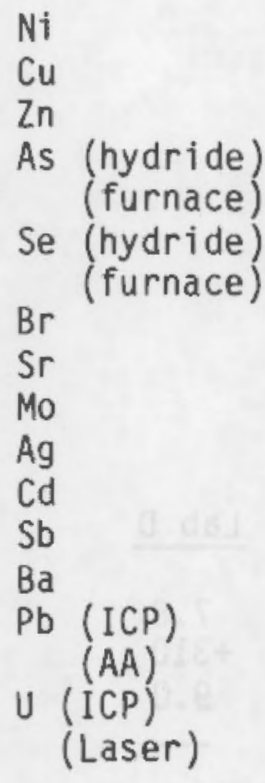

Lab A Lab B Lab C Lab D

\begin{tabular}{|c|c|c|c|}
\hline$<0.06$ & $<0.1$ & $\cdots$ & $<0.2$ \\
\hline 0.16 & $<0.1$ & $<0.05$ & $<0.05$ \\
\hline 0.13 & 0.12 & --- & 0.32 \\
\hline$<0.003$ & $\cdots$ & & -- \\
\hline --. & --. & $<0.05$ & $<0.02$ \\
\hline 0.01 & --- & & --- \\
\hline & & 0.018 & 0.018 \\
\hline 2.2 & $\because-$ & & -- \\
\hline $\begin{array}{r}5.8 \\
0.007\end{array}$ & $\begin{array}{r}6.5 \\
0.06\end{array}$ & $<0.05$ & $\begin{array}{l}4.23 \\
0.03\end{array}$ \\
\hline -- & 0.2 & $<0.05$ & -- \\
\hline 0.004 & 0.02 & $<0.01$ & 0.02 \\
\hline 0.054 & 0.625 & --- & 0.07 \\
\hline 0.024 & 0.022 & $<0.05$ & 0.02 \\
\hline 0.002 & 0.277 & & 0.22 \\
\hline & --- & $<0.0$ & $<0.02$ \\
\hline 51.4 & 53.3 & & -- \\
\hline 54.4 & & & 53.2 \\
\hline
\end{tabular}

-.. = Not analyzed 
TABLE A.2. Well 912 Chemical Analysis (downgradient (of ore zone in reduced zone)

Field Results:

$$
\begin{array}{rl}
\mathrm{T}^{\circ} & 28.4^{\circ} \mathrm{C} \\
\mathrm{pH} & 8.4 \\
\mathrm{Eh} & -85 \mathrm{mV} \\
\text { Conductivity } & 1900 \mu \mathrm{mhos} / \mathrm{cm} \\
\mathrm{S}^{=} & <0.02 \mathrm{mg} / \ell \\
\mathrm{NH}_{4}^{+} & 0.056 \mathrm{mg} / \mathrm{\ell} \\
\mathrm{HCO}_{3}^{-} & 239 \mathrm{mg} / \ell \\
\mathrm{CO}^{2}- & 7.4 \mathrm{mg} / \mathrm{l}
\end{array}
$$

\begin{tabular}{|c|c|c|c|}
\hline 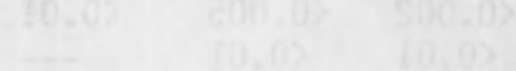 & Lab A & Lab B & Lab C \\
\hline $\mathrm{pH}$ & 8.4 &.-- & --- \\
\hline Eh $(m V)$ & +130 & -- & -- \\
\hline Conductivity (umhos/cm) & 1860 & -- & -- \\
\hline Dissolved Con & ituents & $g / \ell)$ & \\
\hline Li & 0.075 & 0.069 & -- \\
\hline B & 1.03 & 0.97 & -- \\
\hline Dissolved organic carbon & 1.5 & -. & --- \\
\hline $\mathrm{HCO}_{\overline{3}}$ & 216.3 & -- & -- \\
\hline $\mathrm{CO}_{3}^{-}$ & 3.1 & -- & -- \\
\hline $\mathrm{NO}_{2}$ & $<1.0$ & -- & --- \\
\hline $\mathrm{NO}_{3}$ & $<0.2$ & -- & -- \\
\hline$F^{-}$ & 0.71 & $<0.1$ & -- \\
\hline $\mathrm{Na}$ & 3030 & 342 & -- \\
\hline Mg & 4.6 & 5.0 & --- \\
\hline Al̆ & 0.015 & 0.038 & --- \\
\hline Si & 8.2 & 7.94 & -- \\
\hline & $<0.05$ & 0.11 & --- \\
\hline $\mathrm{PO}^{3-}$ & $<0.2$ & - & $-\cdots$ \\
\hline $\begin{array}{l}\mathrm{SO}_{4}^{2-} \\
\mathrm{Cl}^{4}\end{array}$ & $\begin{array}{r}66.2 \\
417\end{array}$ & $\begin{array}{r}79.8 \\
418\end{array}$ &.-- \\
\hline$K($ ICP) & 11.3 & 11.8 & $\ldots$ \\
\hline (AA) & & 13.0 & $-\cdots$ \\
\hline $\mathrm{Ca}$ & 13.1 & 13.4 & $-\cdots$ \\
\hline V & $<0.003$ & --- & $<0.05$ \\
\hline $\mathrm{Cr}$ & $<0.01$ & 0.005 & $<0.040$ \\
\hline Mn & 0.015 & 0.01 & $<0.02$ \\
\hline $\mathrm{Fe}$ & 0.041 & $<0.1$ & $<0.05$ \\
\hline
\end{tabular}

Lab Results:

Lab A ran analyses within 1 week of sampling

Lab B ran analyses within 4 weeks of sampling

Lab C ran analyses within 6 weeks of sampling 
TABLE A.2. (contd)

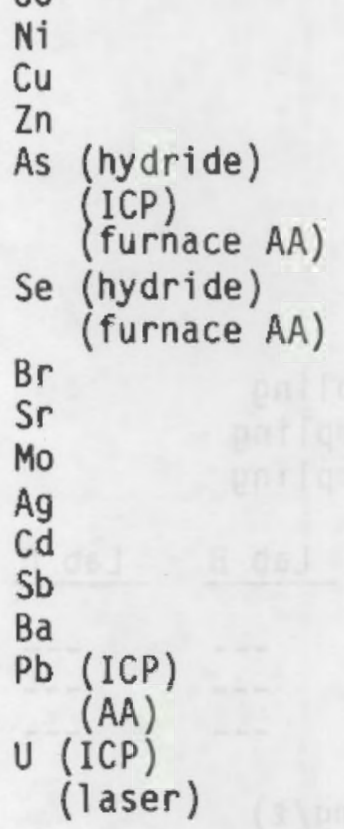

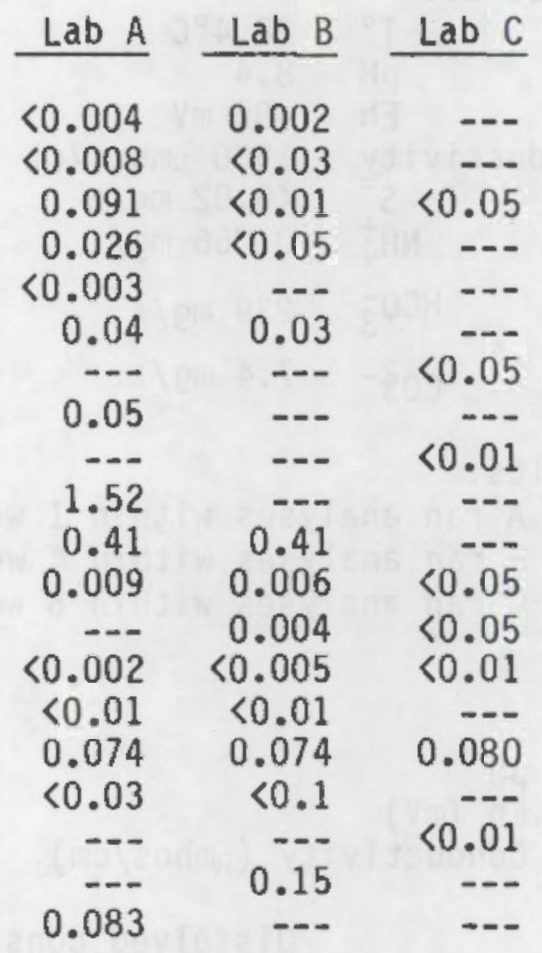




\section{TABLE A.3. Recommended Analytical Techniques}

\begin{tabular}{|c|c|c|c|}
\hline Constituent & Procedure & $\begin{array}{r}\text { Practical Detection } \\
\text { Limit (mg/l) } \\
\end{array}$ & Comments \\
\hline Li & ICP & 0.01 & $\begin{array}{l}\text { Excelient preclsion, no signifleant } \\
\text { Interterences }\end{array}$ \\
\hline 8 & ICP & 0.01 & $\begin{array}{l}\text { Excelient orecision, no signiticant } \\
\text { Interferences }\end{array}$ \\
\hline $\mathrm{HCO}_{3} / \mathrm{CO}_{3}$ & Titration & 10. & Need 20 to $50 \mathrm{~m} / \mathrm{s}$ if low \\
\hline $\begin{array}{l}\text { DIssolvad organic } \\
\text { carbon }\end{array}$ & TOC snalyzer & 0.1 & $\begin{array}{l}\text { Detection IImit much higher If } \\
\text { hlgh-temperature oxidizer used }\end{array}$ \\
\hline $\mathrm{NO}_{3}$ & IC & 0.2 & \\
\hline$F^{3}$ & IC or Electrode & 0.2 & \\
\hline Na & ICP & 0.1 & $\begin{array}{l}\text { Precision fair, use Fiome AA If good } \\
\text { precision necossary }\end{array}$ \\
\hline Mg & ICP & 0.2 & $\begin{array}{l}\text { Precislon very good, watch hlgh U } \\
\text { interferance }\end{array}$ \\
\hline AI & I CP & 0.1 & U Interference if $>5 \mathrm{ppm}$ \\
\hline S! & ICP & 0.06 & U Interterence it >15 $\mathrm{DP}$ m \\
\hline $\mathrm{PO}_{4}$ & IC & $0: 2$ & \\
\hline $\mathrm{SO}_{4}$ & IC & 0.2 & \\
\hline $\mathrm{Cl}^{2}$ & 16 & 0.2 & \\
\hline K & ICP & 0.5 & $\begin{array}{l}\text { Precision fair, wse Flame AA If good } \\
\text { precision necessary }\end{array}$ \\
\hline $\mathrm{Ca}$ & ICP & 0.1 & \\
\hline $\begin{array}{l}\mathrm{V} \\
\mathrm{Cr}\end{array}$ & $A A-G F$ & 0.05 & AA-GF for better precislon \\
\hline $\begin{array}{l}\mathrm{Cr} \\
\mathrm{Mn}\end{array}$ & $\begin{array}{l}\text { ICP } \\
\text { ICP }\end{array}$ & $\begin{array}{l}0.02 \\
0.01\end{array}$ & $\begin{array}{l}\text { AA-GF for better precislon } \\
A A-G F \text { better only if }<0.03 \text { PPa }\end{array}$ \\
\hline $\mathrm{F} \bullet$ & $A A-G F$ & 0.02 & ICP OK if $>0.2 \mathrm{PP}$ \\
\hline Co & ICP & 0.03 & \\
\hline N I & ICP & 0.1 & AA-GF for better precision \\
\hline $\mathrm{Cu}$ & ICP & 0.04 & If strong U Interterence, AA-GF better \\
\hline $2 n$ & I CP & 0.02 & ICP good \\
\hline As & $A A-G F$ & 0.02 & Hydrlde more sensitl ve but takes $50 \mathrm{ml}$ \\
\hline S• & $A A-G F$ & 0.01 & HydrIde no Improvement \\
\hline Br & IC & 0.2 & \\
\hline Sr & $I C P$ & 0.01 & Precision/sensitivity very good \\
\hline Mo & ICP & 0.01 & Precision/sensitivity very good \\
\hline Cd & I CP & 0.01 & Precision/sensitI vity AA-GF no Improvement \\
\hline Sb & $\mathrm{ICP}$ & 0.05 & Precision fair \\
\hline Ba & ICP & 0.01 & Preclsionfsensitivity very good \\
\hline Lo & ICP & 0.1 & Prectsion good \\
\hline Pb & GF $-A A$ & 0.02 & ICP blased hIgh \\
\hline $\mathbf{u}$ & Laser Fluorlmetry & 0.005 & ICP OK If $U>0.5 \mathrm{pP}$ \\
\hline
\end{tabular}




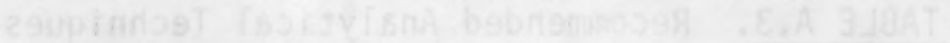

(4)


APPENDIX B

COMPOSITION OF COLUMN EFFLUENTS 


\section{COMPOSITION OF COLUMN EFFLUENTS}

Two series of column experiments were conducted for this study. Four columns were run in each series. The methodology section of this report describes the experiments and the analytical procedures used to determine the composition of the column influent and effluent solutions. This appendix contains eight tables that list the solution compositions for the columns run for this study. A brief description of each table follows:

Test Number

Series 1

Column 1

Series 1

Column 2

Series 1

Column 3

Series 1

Column 4

Series 2

Column 1

Series 2

Column 2

Series 2

Column 3

Series 2

Column 4
Influent Solution

$73_{\mathrm{As}},{ }^{109} \mathrm{Cd}$, and ${ }^{210} \mathrm{~Pb}$ spiked

lixiviant from Well 666

${ }^{51} \mathrm{Cr}$ and ${ }^{75}$ Se spiked lixiviant

from Well 666

${ }^{59} \mathrm{Fe}$ and ${ }^{53} \mathrm{Mn}$ spiked lixiviant

from Well 666

${ }^{228} \mathrm{Ra}$ spiked lixiviant from

Well 666

Ground water from Well 912

Lixiviant from Wel1 666

Lixiviant from Well 666. Influent changes to Well 912 ground water after collecting 3 pore volumes of effluent.
Column Pore

Volume, ml Table Number

150

B.1.1

150

B.1.2

150

B.1.3

150

B. 1.4

150

B.2.1

150

B.2.2

300

B. 2.3

600

B.2.4 


\section{TABLE B.1.1. Series 1 Column 1 Effluent Composition (mg/L or counts/min)}

\begin{tabular}{|c|c|c|c|c|c|c|c|c|c|c|c|c|}
\hline \multirow{2}{*}{\multicolumn{2}{|c|}{$\begin{array}{c}\text { Constituent } \\
(\mathrm{mg} / \mathrm{L})\end{array}$}} & \multirow{2}{*}{$\begin{array}{l}\text { Original } \\
\text { Lixiviant }\end{array}$} & \multirow{2}{*}{$\begin{array}{c}\text { Radiotraced } \\
\text { Lixiviant } \\
\end{array}$} & \multicolumn{9}{|c|}{ Effluents (pore volumes) } \\
\hline & & & & 0.31 & 1.04 & 2.32 & 3.43 & 4.93 & 6.93 & 9.87 & 11.62 & 12.56 \\
\hline Li & & 0.20 & 0.25 & 0.26 & 0.19 & 0.2 & 0.2 & 0.2 & 0.2 & 0.2 & 0.2 & 0.2 \\
\hline B & & 1.33 & 1.90 & 0.68 & 1.08 & 1.6 & 1.6 & 1.6 & 1.4 & 1.5 & 1.5 & 1.5 \\
\hline $\mathrm{NO}_{3}$ & 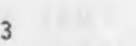 & 0.54 & 10.6 & 5.8 & 9.0 & 9.6 & 7.1 & 7.7 & 8.3 & 8.3 & 7.1 & 9.0 \\
\hline$F$ & & 0.2 & -- & - & -- & -. & -- & $\cdots$ & 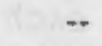 & -- & $\cdots$ & -- \\
\hline $\mathrm{Na}$ & t & 944 & 1400 & 1580 & 1380 & 1250 & 1260 & 1250 & 1250 & 1270 & 1240 & 1270 \\
\hline Mg & & 91 & 99 & 167 & 120 & 92 & 89 & 88.8 & 83.8 & 80.5 & 79.3 & 78.2 \\
\hline Al & & $<0.3$ & $<0.85$ & $<0.3$ & $<0.3$ & $<0.5$ & $<0.5$ & $<0.5$ & $<0.5$ & $<0.5$ & $<0.5$ & $<0.5$ \\
\hline Si & & 9.5 & 12.4 & 3.8 & 4.9 & 6.4 & 6.6 & 6.8 & 6.9 & 7.2 & 7.53 & 7.50 \\
\hline P & & $<0.2$ & $<0.1$ & $<0.1$ & 0.17 & 0.1 & 0.15 & 0.20 & 0.14 & 0.2 & $<0.2$ & $<0.2$ \\
\hline $\mathrm{SO}_{4}$ & & 1394 & 1485 & 4080 & 2333 & 1500 & 1440 & 1440 & 1420 & 1440 & 1420 & 1420 \\
\hline $\mathrm{Cl}$ & & 1046 & 1080 & 630 & 970 & 1030 & 1030 & 1030 & 1020 & 1030 & 1030 & 1020 \\
\hline K & & 34 & 48.3 & 99 & 83 & 77 & 67 & 64 & 60 & 56 & 52 & 53 \\
\hline $\mathrm{Ca}$ & & 320 & 156 & 499 & 351 & 247 & 233 & 238 & 213 & 222 & 219 & 211 \\
\hline$v$ & & $<0.05$ & -- & -. & -- & -. & -- & $\cdots$ & -- & - & -- & - \\
\hline $\mathrm{Cr}$ & & $<0.02$ & $<0.2$ & $<0.02$ & 0.02 & 0.03 & 0.02 & 0.02 & $<0.02$ & $<0.02$ & 0.02 & 0.02 \\
\hline & $\begin{array}{l}(1 C P) \\
(A A)\end{array}$ & $\begin{array}{l}0.43 \\
0.49\end{array}$ & $\begin{array}{l}<0.02 \\
<0.02\end{array}$ & $\begin{array}{l}0.16 \\
0.17\end{array}$ & $\begin{array}{l}0.10 \\
0.10\end{array}$ & $\begin{array}{r}0.03 \\
0.025\end{array}$ & $\begin{array}{l}0.025 \\
<0.02\end{array}$ & $\begin{array}{r}0.03 \\
0.025\end{array}$ & $\begin{array}{r}<0.025 \\
<0.02\end{array}$ & $\begin{array}{r}<0.03 \\
0.04\end{array}$ & $\begin{array}{r}0.05 \\
0.038\end{array}$ & $\begin{array}{r}0.05 \\
0.043\end{array}$ \\
\hline $\mathrm{Fe}$ & $\left(\begin{array}{l}\text { ICP }) \\
(A A)\end{array}\right.$ & $\begin{array}{l}0.12 \\
0.08\end{array}$ & $\begin{array}{l}<0.09 \\
<0.02\end{array}$ & $\begin{array}{l}<0.05 \\
<0.02\end{array}$ & $\begin{array}{l}<0.06 \\
<0.02\end{array}$ & $\begin{array}{l}<0.06 \\
<0.02\end{array}$ & $\begin{array}{l}<0.06 \\
<0.02\end{array}$ & $\begin{array}{l}<0.06 \\
<0.02\end{array}$ & $\begin{array}{l}<0.06 \\
<0.02\end{array}$ & $\begin{array}{r}<0.05 \\
0.02\end{array}$ & $\begin{array}{l}<0.06 \\
<0.02\end{array}$ & $\begin{array}{l}<0.04 \\
<0.02\end{array}$ \\
\hline $\mathrm{Co}$ & & $<0.2$ & $<0.04$ & $<0.01$ & 0.03 & 0.05 & 0.04 & 0.05 & 0.03 & 0.04 & 0.03 & 0.03 \\
\hline Ni & & $<0.2$ & $<0.05$ & $<0.02$ & 0.02 & 0.03 & 0.03 & 0.03 & 0.02 & 0.03 & 0.03 & 0.03 \\
\hline $\mathrm{Cu}$ & $\begin{array}{l}(\text { ICP }) \\
(\mathrm{Aa})\end{array}$ & $\begin{array}{r}0.16 \\
<0.05\end{array}$ & $<0.04$ & $<0.04$ & $<0.04$ & $<0.06$ & $<0.06$ & $<0.04$ & 0.06 & $\begin{array}{r}0.04 \\
. .\end{array}$ & $<0.04$ & $<0.04$ \\
\hline $2 n$ & & 0.13 & 0.06 & 0.8 & 0.3 & 0.17 & 0.04 & 0.15 & 0.04 & 0.04 & 0.05 & 0.04 \\
\hline & $\begin{array}{l}(I C P) \\
(A A)\end{array}$ & $<0 . \ddot{05}$ & $\begin{array}{r}0.22 \\
<0.02\end{array}$ & $\begin{array}{l}<0.09 \\
<0.02\end{array}$ & $\begin{array}{r}0.18 \\
<0.02\end{array}$ & $\begin{array}{r}0.20 \\
<0.02\end{array}$ & $\begin{array}{r}0.20 \\
<0.02\end{array}$ & $\begin{array}{r}0.21 \\
<0.02\end{array}$ & $\begin{array}{r}0.08 \\
<0.02\end{array}$ & $\begin{array}{r}0.18 \\
<0.02\end{array}$ & $\begin{array}{r}0.21 \\
<0.02\end{array}$ & $\begin{array}{r}0.23 \\
<0.02\end{array}$ \\
\hline Se & & 0.02 & 0.02 & 0.026 & 0.015 & 0.015 & 0.011 & $<0.01$ & 0.014 & 0.014 & 0.010 & 0.016 \\
\hline $\mathrm{Br}$ & $2 x^{2}=1$ & 2.2 & 2.0 & 2.0 & 2.0 & 2.0 & 2.0 & 2.0 & 2.0 & 2.0 & 2.0 & 2.0 \\
\hline Sr & & 5.8 & 3.73 & 14.7 & 10.4 & 7.7 & 7.0 & 7.0 & 6.6 & 6.6 & 6.23 & 6.53 \\
\hline Mo & & 0.01 & 0.01 & 0.05 & 0.04 & 0.03 & 0.03 & 0.03 & 0.04 & 0.03 & 0.03 & 0.03 \\
\hline $\mathrm{Cd}$ & & $<0.04$ & $<0.04$ & 0.009 & 0.012 & 0.012 & 0.008 & 0.012 & 0.013 & 0.009 & 0.10 & 0.012 \\
\hline Sb & & 0.05 & $<0.05$ & $<0.05$ & 0.10 & 0.10 & 0.08 & 0.09 & 0.05 & 0.04 & 0.06 & $<0.05$ \\
\hline $\mathrm{Ba}$ & & 0.024 & $<0.02$ & 0.07 & 0.09 & 0.08 & 0.09 & 0.10 & .0 .03 & 0.03 & 0.03 & 0.10 \\
\hline La & & $<0.8$ & 0.22 & 0.25 & 0.25 & 0.23 & 0.23 & 0.23 & 0.22 & 0.22 & 0.22 & 0.22 \\
\hline & $\begin{array}{l}(I C P) \\
(A A)\end{array}$ & $<0 . \overline{01}$ & $\begin{array}{r}0.13 \\
<0.02\end{array}$ & $\begin{array}{r}0.11 \\
<0.02\end{array}$ & $\begin{array}{r}0.28 \\
<0.02\end{array}$ & $\begin{array}{r}0.31 \\
<0.02\end{array}$ & $\begin{array}{r}0.26 \\
<0.02\end{array}$ & $\begin{array}{r}0.31 \\
<0.02\end{array}$ & $\begin{array}{r}0.26 \\
<0.02\end{array}$ & $\begin{array}{r}0.27 \\
<0.02\end{array}$ & $\begin{array}{r}0.31 \\
<0.02\end{array}$ & $\begin{array}{r}0.32 \\
<0.02\end{array}$ \\
\hline U & & 54.4 & 56.7 & 11.5 & 30.6 & 45.9 & 54.2 & 55.0 & 54.5 & 55.7 & 54.5 & 52.5 \\
\hline pH & & 7.9 & 8.1 & 7.8 & 8.0 & 7.8 & 7.9 & - & -- & -. & 8.1 & -- \\
\hline $\mathrm{HCO}$ & $\mathrm{O}_{3}$ & 634 & 230.4 & 91.1 & 254.9 & 200.4 & -- & $\cdots$ & - & -- & -. & -- \\
\hline & $(m V)$ & +330 & +286 & +120 & +240 & +240 & -. & $\cdots$ & +240 & -. & +230 & -. \\
\hline & $\begin{array}{l}\text { dionuclide } \\
\text { ounts/min) }\end{array}$ & & & & & & & & & & & \\
\hline $73_{\mathrm{A}}$ & As & -- & 1203 & 0 & 0 & 0 & 0.5 & 1.3 & 1.8 & 2.9 & 3.6 & 3.9 \\
\hline 109 & ${ }^{9} \mathrm{Cd}$ & - & 279 & 0 & 0 & 0 & 0 & 0 & 0 & 0 & 0 & 0 \\
\hline 210 & $O_{p b}$ & -- & 140 & 0 & 0 & 0 & 0 & 0 & 0 & 0 & 0 & 0 \\
\hline
\end{tabular}

- = Not analyzed 


\section{TABLE B.1.2. Series 1 Column 2 Effluent Composition (mg/L or counts/min)}

\begin{tabular}{|c|c|c|c|c|c|c|c|c|c|c|c|c|}
\hline \multirow{2}{*}{\multicolumn{2}{|c|}{$\begin{array}{c}\text { Constituent } \\
(\mathrm{mg} / \mathrm{L})\end{array}$}} & \multirow{2}{*}{$\begin{array}{l}\text { Original } \\
\text { Lixiviant } \\
\end{array}$} & \multirow{2}{*}{$\begin{array}{c}\text { Radiot raced } \\
\text { Lixiviant } \\
\end{array}$} & \multicolumn{9}{|c|}{ Effluents (pore volumes) } \\
\hline & & & & 0.32 & 1.28 & 2.55 & 3.98 & 5.15 & 6.15 & 7.50 & 10.6 & 13.68 \\
\hline Li & & 0.20 & 0.24 & 0.22 & 0.18 & 0.23 & 0.23 & 0.23 & 0.17 & 0.19 & 0.18 & 0.18 \\
\hline B & & 1.33 & 1.46 & 0.59 & 1.4 & 1.66 & 1.54 & 1.56 & 1.40 & 1.45 & 1.44 & 1.50 \\
\hline $\mathrm{NO}_{3}$ & 3 & 0.54 & 1.6 & $<1.3$ & 1.9 & 1.3 & $<1.3$ & $<1.3$ & $<1.3$ & $<1.3$ & $<1.3$ & 1.3 \\
\hline$F$ & & 0.2 & - & -- & $\cdots$ & -- & & & & & & \\
\hline Na & t & 944 & 1220 & 1580 & 1290 & 1190 & 1170 & 1180 & 1190 & 1180 & 1200 & 1200 \\
\hline Mg & & 91 & 94 & 173 & 106 & 91 & 90 & 88 & 86 & 82 & 79 & 76 \\
\hline Al & & $<0.3$ & 0.45 & $<0.3$ & $<0.3$ & $<0.3$ & $<0.3$ & $<0.3$ & $<0.3$ & $<0.3$ & $<0.3$ & $<0.3$ \\
\hline Si & & 9.5 & 10.7 & 3.5 & 5.0 & 6.4 & 6.3 & 6.6 & 6.4 & 6.1 & 7.1 & 7.8 \\
\hline $\mathrm{P}$ & & $<0.2$ & $<0.2$ & $<0.2$ & $<0.3$ & $<0.3$ & $<0.1$ & $<0.2$ & $<0.2$ & $<0.2$ & $<0.2$ & $<0.2$ \\
\hline $\mathrm{SO}_{4}$ & & 1394 & 1425 & 4250 & 2140 & 1560 & 1440 & 1440 & 1440 & 1440 & 1430 & 1440 \\
\hline $\mathrm{Cl}$ & & 1046 & 1035 & 640 & 1040 & 1060 & 1060 & 1060 & 1060 & 1030 & 1040 & 1040 \\
\hline K & & 34 & 40 & 79 & 64 & 59 & 56 & 57 & 55 & 60 & 50 & 45 \\
\hline $\mathrm{Ca}$ & & 320 & 175 & 496 & 308 & 244 & 247 & 227 & 198 & 208 & 225 & 218 \\
\hline v & & $<0.05$ & -- & -- & - & -- & -- & -- & -. & -- & -- & -- \\
\hline $\mathrm{Cr}$ & & $<0.02$ & 0.02 & 0.02 & 0.04 & 0.03 & 0.02 & $<0.02$ & $<0.02$ & $<0.02$ & $<0.02$ & 0.03 \\
\hline & $\begin{array}{l}(\text { ICP }) \\
(A A)\end{array}$ & & $\begin{array}{r}0.03 \\
<0.02\end{array}$ & $\begin{array}{r}0.14 \\
0.126\end{array}$ & $\begin{array}{r}0.08 \\
0.065\end{array}$ & $\begin{array}{r}0.04 \\
0.023\end{array}$ & $\begin{array}{r}0.04 \\
0.032\end{array}$ & $\begin{array}{r}0.02 \\
0.026\end{array}$ & $\begin{array}{r}0.02 \\
0.031\end{array}$ & $\begin{array}{l}<0.01 \\
<0.02\end{array}$ & $\begin{array}{r}0.08 \\
0.062\end{array}$ & $\begin{array}{r}0.06 \\
0.046\end{array}$ \\
\hline $\mathrm{Fe}$ & $\begin{array}{l}(I C P) \\
(A A)\end{array}$ & $\begin{array}{l}0.12 \\
0.08\end{array}$ & $\begin{array}{l}<0.1 \\
0.035\end{array}$ & $\begin{array}{r}0.02 \\
<0.02\end{array}$ & $\begin{array}{r}0.05 \\
<0.02\end{array}$ & $\begin{array}{l}<0.05 \\
<0.02\end{array}$ & $\begin{array}{l}<0.05 \\
<0.02\end{array}$ & $\begin{array}{l}<0.05 \\
<0.02\end{array}$ & $\begin{array}{l}<0.05 \\
<0.02\end{array}$ & $\begin{array}{l}<0.05 \\
<0.02\end{array}$ & $\begin{array}{l}<0.05 \\
<0.02\end{array}$ & $\begin{array}{l}<0.05 \\
<0.02\end{array}$ \\
\hline Co & & $<0.2$ & 0.05 & 0.05 & 0.06 & 0.06 & 0.04 & 0.03 & 0.03 & 0.02 & 0.05 & 0.05 \\
\hline $\mathrm{Ni}$ & & $<0.2$ & 0.22 & 0.04 & 0.07 & 0.06 & 0.03 & 0.03 & 0.03 & 0.02 & 0.04 & 0.05 \\
\hline $\mathrm{Cu}$ & $\begin{array}{l}(I C P) \\
(A A)\end{array}$ & $\begin{array}{r}0.16 \\
<0.05\end{array}$ & $<0.06$ & $<0.05$ & 0.05 & $\begin{array}{r}0.04 \\
--\end{array}$ & $<0.04$ & $\begin{array}{r}<0.04 \\
-.\end{array}$ & $<0.04$ & $<0.04$ & $<0.04$ & $<0.04$ \\
\hline $2 n$ & 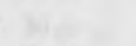 & 0.13 & 0.43 & 0.12 & 0.23 & 0.33 & 0.05 & $<0.02$ & $<0.02$ & 0.04 & 0.07 & 0.04 \\
\hline As & $\begin{array}{l}(I C P) \\
(A A)\end{array}$ & $<0 . \ddot{05}$ & $\begin{array}{r}0.23 \\
<0.02\end{array}$ & $\begin{array}{r}0.21 \\
<0.02\end{array}$ & $\begin{array}{r}0.34 \\
<0.02\end{array}$ & $\begin{array}{r}0.26 \\
<0.02\end{array}$ & $\begin{array}{r}0.20 \\
<0.02\end{array}$ & $\begin{array}{r}0.24 \\
<0.02\end{array}$ & $\begin{array}{r}0.23 \\
<0.02\end{array}$ & $\begin{array}{r}0.13 \\
<0.02\end{array}$ & $\begin{array}{r}0.20 \\
<0.02\end{array}$ & $\begin{array}{r}0.28 \\
<0.02\end{array}$ \\
\hline Se & & 0.02 & 0.016 & 0.052 & 0.025 & 0.012 & $<0.01$ & $<0.01$ & $<0.01$ & $<0.01$ & 0.015 & 0.012 \\
\hline $\mathrm{Br}$ & & 2.2 & 1.8 & 2.0 & 2.0 & 2.0 & 2.0 & 2.0 & 2.0 & 2.0 & 2.0 & 2.0 \\
\hline Sr & & 5.8 & 4.7 & 14.3 & 8.8 & 7.3 & 7.4 & 6.9 & 5.7 & 6.6 & 6.5 & 6.2 \\
\hline Mo & 1 & 0.01 & 0.03 & 0.12 & 0.08 & 0.05 & 0.04 & 0.03 & 0.03 & 0.02 & 0.04 & 0.05 \\
\hline Cd & 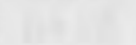 & $<0.04$ & 0.01 & 0.01 & 0.02 & 0.01 & 0.01 & 0.01 & 0.01 & 0.01 & 0.01 & 0.01 \\
\hline Sb & 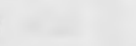 & 0.05 & 0.06 & 0.04 & 0.12 & 0.19 & 0.09 & 0.08 & 0.06 & 0.06 & 0.07 & 0.10 \\
\hline $\mathrm{Ba}$ & & 0.024 & 0.019 & 0.07 & 0.09 & 0.10 & 0.07 & 0.06 & 0.03 & 0.02 & 0.03 & 0.03 \\
\hline La & 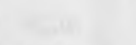 & $<0.8$ & 0.23 & 0.12 & 0.26 & 0.26 & 0.23 & 0.22 & 0.21 & 0.17 & 0.23 & 0.24 \\
\hline & $\begin{array}{l}(I C P) \\
(A R)\end{array}$ & $<0 . \overline{01}$ & $\begin{array}{r}0.3 \\
<0.02\end{array}$ & $\begin{array}{r}0.2 \\
<0.02\end{array}$ & $\begin{array}{r}0.6 \\
<0.02\end{array}$ & $\begin{array}{r}0.4 \\
<0.02\end{array}$ & $\begin{array}{r}0.25 \\
<0.02\end{array}$ & $\begin{array}{r}0.20 \\
<0.02\end{array}$ & $\begin{array}{r}0.23 \\
<0.02\end{array}$ & $\begin{array}{r}0.15 \\
<0.02\end{array}$ & $\begin{array}{r}0.31 \\
<0.02\end{array}$ & $\begin{array}{r}0.36 \\
<0.02\end{array}$ \\
\hline U & 1 & 54.5 & 46.0 & 20.1 & 23.9 & 43.0 & 52.2 & 57.5 & 57.5 & 57.5 & 52.7 & 55.1 \\
\hline $\mathrm{pH}$ & & 7.9 & 8.2 & 7.9 & 8.0 & 7.7 & 7.8 & 7.6 & 8.0 & 8.0 & 7.7 & 7.9 \\
\hline $\mathrm{HCO}$ & & 634 & 262.8 & 70.3 & -- & -- & -- & -- & - & -- & - & -- \\
\hline & $(m V)$ & +330 & +236 & -. & $\cdots$ & -- & -- & -. & -- & -- & - & +272 \\
\hline & dionuclid & & & & & & & & & & & \\
\hline & & - & 118 & 0 & 0 & 0 & -- & 0 & 0 & 0 & 0 & 0 \\
\hline $75_{5}$ & & $\ldots$ & 1772 & 56 & 251 & 326 & -- & 217 & 257 & 264 & 355 & 356 \\
\hline
\end{tabular}

$\overline{\ldots=\text { Not Analyzed }}$ 
TABLE B.1.3. Series 1 Column 3 Effluent Composition (mg/L or counts/min)

\begin{tabular}{|c|c|c|c|c|c|c|c|c|c|c|c|}
\hline \multirow{2}{*}{\multicolumn{2}{|c|}{$\begin{array}{c}\text { Const ituent } \\
(\mathrm{mg} / \mathrm{L})\end{array}$}} & \multirow{2}{*}{$\begin{array}{l}\text { Original } \\
\text { Lixiviant } \\
\end{array}$} & \multirow{2}{*}{$\begin{array}{c}\text { Radiotraced } \\
\text { Lixiviant } \\
\end{array}$} & \multicolumn{8}{|c|}{ Effluents (pore volumes) } \\
\hline & & & & 0.36 & 1.15 & 3.14 & 4.09 & 5.47 & 8.70 & 10.25 & 12.63 \\
\hline Li & 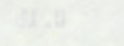 & 0.20 & 0.19 & 0.32 & 0.15 & 0.24 & 0.22 & 0.21 & 0.18 & 0.16 & 0.16 \\
\hline B & & 1.33 & 1.90 & 0.51 & 0.87 & 1.78 & 1.66 & 1.57 & 1.33 & 1.47 & 1.52 \\
\hline $\mathrm{NO}_{3}$ & & 0.54 & $<1.3$ & 3.8 & 1.6 & $<1.3$ & $<1.3$ & $<1.3$ & $<1.3$ & $<1.3$ & $<1.3$ \\
\hline $\mathbf{F}$ & & 0.2 & - & - & - & - & - & - & -- & -. & \\
\hline $\mathrm{Na}$ & & 944 & 1333 & 1530 & 1250 & 1200 & 1200 & 1180 & 1170 & 1190 & 1170 \\
\hline $\mathrm{Mg}$ & & 91 & 99 & 162 & 92 & 84 & 84 & 83 & 81 & 79 & 78 \\
\hline Al & & $<0.3$ & $<0.3$ & $<0.3$ & $<0.3$ & $<0.3$ & $<0.3$ & $<0.3$ & $<0.3$ & $<0.3$ & $<0.3$ \\
\hline St & & 9.5 & 11.9 & 3.1 & 4.1 & 6.6 & 6.5 & 6.7 & 6.0 & 6.3 & 6.7 \\
\hline$P$ & & $<0.2$ & $<0.2$ & $<0.2$ & $<0.2$ & $<0.3$ & $<0.2$ & $<0.2$ & $<0.2$ & $<0.3$ & $<0.3$ \\
\hline $\mathrm{SO}_{4}$ & 4 & 1394 & 1455 & 3890 & 1830 & 1440 & 1440 & 1430 & 1390 & 1390 & 1390 \\
\hline Cl & & 1046 & 1070 & 720 & 1030 & 1040 & 1060 & 1060 & 1030 & 1030 & 1010 \\
\hline K & & 34 & 44 & 78 & 66 & 60 & 59 & 57 & 52 & 53 & 48 \\
\hline $\mathrm{Ca}$ & & 320 & 171 & 479 & 260 & 222 & 222 & 226 & 217 & 223 & 222 \\
\hline v & & $<0.05$ & -. & -- & -. & -- & -- & -- & - & -. & -- \\
\hline $\mathrm{Cr}$ & & $<0.02$ & 0.03 & 0.02 & 0.02 & 0.03 & 0.03 & 0.06 & 0.02 & $<0.02$ & 0.03 \\
\hline Mn & $\begin{array}{l}(I C P) \\
(A A)\end{array}$ & $\begin{array}{l}0.43 \\
0.49\end{array}$ & $\begin{array}{r}0.03 \\
0.023\end{array}$ & $\begin{array}{r}0.11 \\
0.096\end{array}$ & $\begin{array}{r}0.06 \\
0.043\end{array}$ & $\begin{array}{r}0.04 \\
<0.02\end{array}$ & $\begin{array}{r}0.04 \\
<0.02\end{array}$ & $\begin{array}{l}0.05 \\
0.02\end{array}$ & $\begin{array}{r}0.04 \\
0.023\end{array}$ & $\begin{array}{r}0.08 \\
0.060\end{array}$ & $\begin{array}{r}0.10 \\
0.079\end{array}$ \\
\hline $\mathrm{Fe}$ & $\begin{array}{l}(I C P) \\
(A A)\end{array}$ & $\begin{array}{l}0.12 \\
0.08\end{array}$ & $\begin{array}{l}<0.05 \\
0.038\end{array}$ & $\begin{array}{l}<0.05 \\
<0.02\end{array}$ & $\begin{array}{l}<0.05 \\
<0.02\end{array}$ & $\begin{array}{r}<0.05 \\
0.24\end{array}$ & $\begin{array}{l}<0.05 \\
<0.02\end{array}$ & $\begin{array}{l}<0.05 \\
<0.02\end{array}$ & $\begin{array}{l}<0.05 \\
<0.02\end{array}$ & $\begin{array}{l}<0.05 \\
<0.02\end{array}$ & $\begin{array}{l}>0.05 \\
<0.02\end{array}$ \\
\hline Co & 25.60 & $<0.02$ & $<0.05$ & $<0.05$ & $<0.05$ & $<0.07$ & $<0.07$ & $<0.08$ & $<0.04$ & $<0.05$ & $<0.07$ \\
\hline $\mathrm{Ni}$ & & $<0.2$ & 0.29 & $<0.2$ & $<0.05$ & 0.04 & $<0.05$ & $<0.05$ & $<0.03$ & $<0.04$ & $<0.05$ \\
\hline & $\begin{array}{l}\text { (ICP) } \\
(A A)\end{array}$ & $\begin{array}{r}0.16 \\
<0.05\end{array}$ & $<0.1$ & $<0.05$ & $\begin{array}{r}<0.07 \\
--\end{array}$ & $\begin{array}{r}<0.07 \\
\ldots\end{array}$ & $<0.07$ & $<0.10$ & $<0.09$ & $\begin{array}{r}<0.07 \\
. .\end{array}$ & $<0.07$ \\
\hline $\mathrm{Zn}$ & & 0.13 & 0.71 & 0.24 & 0.24 & 0.09 & 0.07 & 0.13 & 0.05 & 0.06 & 0.06 \\
\hline & $\left(\begin{array}{l}\text { ICP }) \\
(A A)\end{array}\right.$ & $<0 . \overline{05}$ & $\begin{array}{r}0.27 \\
<0.02\end{array}$ & $\begin{array}{r}0.19 \\
<0.02\end{array}$ & $\begin{array}{r}0.24 \\
<0.02\end{array}$ & $\begin{array}{r}0.35 \\
<0.02\end{array}$ & $\begin{array}{r}0.27 \\
<0.02\end{array}$ & $\begin{array}{r}0.36 \\
<0.02\end{array}$ & $\begin{array}{r}0.20 \\
<0.02\end{array}$ & $\begin{array}{r}0.24 \\
<0.02\end{array}$ & $\begin{array}{r}0.33 \\
<0.02\end{array}$ \\
\hline Se & & 0.02 & 0.02 & 0.027 & 0.019 & $<0.01$ & $<0.01$ & $<0.01$ & $<0.01$ & $<0.01$ & $<0.01$ \\
\hline $8 r$ & & 2.2 & 2.0 & 2.0 & 2.0 & 2.0 & 2.0 & 2.0 & 2.0 & 2.0 & 2.0 \\
\hline Sr & & 5.8 & 3.7 & 13.8 & 7.52 & 6.8 & 6.7 & 6.7 & 6.6 & 6.6 & 6.6 \\
\hline Mo & 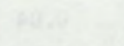 & 0.01 & 0.04 & 0.13 & 0.07 & 0.07 & 0.06 & 0.06 & 0.04 & 0.04 & 0.06 \\
\hline Co & $5=0$ & $<0.04$ & 0.014 & 0.007 & 0.012 & 0.019 & 0.015 & 0.019 & 0.010 & 0.015 & 0.015 \\
\hline Sb & cla & 0.05 & 0.12 & 0.14 & 0.11 & 0.18 & 0.20 & 0.25 & 0.10 & 0.16 & 0.16 \\
\hline $\mathrm{Ba}$ & & 0.024 & 0.021 & 0.07 & 0.07 & 0.09 & 0.07 & 0.09 & 0.03 & 0.03 & 0.03 \\
\hline La & & $<0.8$ & 0.25 & 0.12 & 0.23 & 0.27 & 0.26 & 0.29 & 0.23 & 0.25 & 0.26 \\
\hline $\mathrm{PD}$ & $\begin{array}{l}(I C P) \\
(A A)\end{array}$ & $<0 . \overline{01}$ & $\begin{array}{l}0.3 \\
0.2\end{array}$ & $\begin{array}{r}0.2 \\
<0.02\end{array}$ & $\begin{array}{r}0.4 \\
<0.02\end{array}$ & $\begin{array}{r}0.2 \\
<0.02\end{array}$ & $\begin{array}{r}0.3 \\
<0.02\end{array}$ & $\begin{array}{r}0.4 \\
<0.02\end{array}$ & $\begin{array}{r}0.2 \\
<0.02\end{array}$ & $\begin{array}{r}0.2 \\
<0.02\end{array}$ & $\begin{array}{r}0.3 \\
<0.02\end{array}$ \\
\hline U & & 54.4 & 56.7 & 0.6 & 16.9 & 53.0 & 51.8 & 52.2 & 52.4 & 50.5 & 47.1 \\
\hline $\mathrm{pH}$ & & 7.9 & 8.3 & - & 8.2 & 7.8 & 7.9 & -- & 8.3 & - & -- \\
\hline $\mathrm{HCO}$ & & 634 & 309.6 & 57.2 & 208.1 & 221.2 & 216.0 & 236.8 & 216.0 & 239.3 & 221.2 \\
\hline & $(m V)$ & +330 & +280 & -- & - & .. & -- & -- & - & - & -- \\
\hline & $\begin{array}{l}\text { Aionuclide } \\
\text { punts/min) }\end{array}$ & & & & & & & & & & \\
\hline $59_{F}$ & & -- & 260 & 0 & 0 & 0 & 0 & 0 & 0.17 & 0.13 & 0 \\
\hline 54 & & .. & 307 & 0 & 0 & 0 & 0.13 & 0 & 0 & 0 & 0.4 \\
\hline
\end{tabular}

-- = Not Analyzed 


\section{TABLE B.1.4. Series 1 Column 4 Effluent Composition (mg/L or counts/min)}

\begin{tabular}{|c|c|c|c|c|c|c|c|c|c|c|c|}
\hline \multirow{2}{*}{\multicolumn{2}{|c|}{$\begin{array}{c}\text { Const ituent } \\
\text { (mg/L) }\end{array}$}} & \multirow{2}{*}{$\begin{array}{l}\text { Original } \\
\text { Lixiviant } \\
\end{array}$} & \multirow{2}{*}{$\begin{array}{c}\text { Radiotraced } \\
\text { Lixiviant } \\
\end{array}$} & \multicolumn{8}{|c|}{ Effluents (pore volumes) } \\
\hline & & & & 0.31 & 1.21 & 2.47 & 3.78 & 6.91 & 8.38 & 10.13 & 11.03 \\
\hline Li & & 0.20 & 0.22 & 0.20 & 0.15 & 0.18 & 0.16 & 0.20 & 0.20 & 0.19 & 0.21 \\
\hline B & & 1.33 & 1.50 & 0.57 & 1.43 & 1.66 & 1.51 & 1.35 & 1.44 & 1.45 & 1.49 \\
\hline $\mathrm{NO}_{3}$ & & 0.54 & $<1.3$ & $<1.3$ & $<1.3$ & $<1.3$ & $<1.3$ & 3.8 & $<1.3$ & 5.8 & 6.4 \\
\hline F & & 0.20 & - & - & -- & - & $\cdots$ & $*$ & - & -- & -- \\
\hline $\mathrm{Na}$ & & 944 & 1260 & 1510 & 1180 & 1260 & 1230 & 1230 & 1180 & 1220 & 1240 \\
\hline Mg & & 91 & 92 & 152 & 84 & 85 & 84 & 84 & 82 & 82 & 81 \\
\hline A] & & $<0.3$ & $<0.3$ & $<0.3$ & $<0.3$ & $<0.3$ & $<0.3$ & $<0.3$ & $<0.3$ & $<0.3$ & $<0.3$ \\
\hline Si & & 9.5 & 10.7 & 3.2 & 5.3 & 6.2 & 6.4 & 6.2 & 6.5 & 6.7 & 6.8 \\
\hline P & & $<0.2$ & $<0.1$ & $<0.3$ & $<0.2$ & $<0.1$ & $<0.2$ & $<0.2$ & $<0.2$ & $<0.2$ & $<0.1$ \\
\hline $\mathrm{SO}_{4}$ & & 1394 & 1375 & 3610 & 1500 & 1420 & 1420 & 1390 & 1390 & 1440 & 1390 \\
\hline $\mathrm{Cl}$ & & 1046 & 1025 & 690 & 1030 & 1030 & 1020 & 1030 & 1030 & 1020 & 1030 \\
\hline$k$ & & 34 & 42 & 73 & 56 & 62 & 59 & 57 & 54 & 55 & 55 \\
\hline $\mathrm{Ca}$ & & 320 & 168 & 441 & 230 & 221 & 226 & 223 & 230 & 230 & 226 \\
\hline$v$ & & $<0.05$ & -- & - & - & - & -- & - & - & -- & -- \\
\hline $\mathrm{Cr}$ & & $<0.02$ & $<0.02$ & $<0.02$ & 0.02 & $<0.02$ & $<0.02$ & $<0.02$ & $<0.02$ & 0.02 & $<0.02$ \\
\hline Mn & $\begin{array}{l}(1 C P) \\
(A A)\end{array}$ & $\begin{array}{l}0.43 \\
0.49\end{array}$ & $\begin{array}{r}0.017 \\
<0.020\end{array}$ & $\begin{array}{r}0.11 \\
0.106\end{array}$ & $\begin{array}{r}0.04 \\
0.026\end{array}$ & $\begin{array}{r}0.03 \\
<0.02\end{array}$ & $\begin{array}{r}0.04 \\
<0.02\end{array}$ & $\begin{array}{r}0.03 \\
0.123\end{array}$ & $\begin{array}{r}0.06 \\
0.051\end{array}$ & $\begin{array}{r}0.08 \\
0.070\end{array}$ & $\begin{array}{l}0.07 \\
0.059\end{array}$ \\
\hline $\mathrm{Fe}$ & $\begin{array}{l}(I C P) \\
(A A)\end{array}$ & $\begin{array}{l}0.12 \\
0.08\end{array}$ & $\begin{array}{l}<0.05 \\
<0.02\end{array}$ & $\begin{array}{l}<0.05 \\
<0.02\end{array}$ & $\begin{array}{l}<0.05 \\
<0.02\end{array}$ & $\begin{array}{l}<0.05 \\
<0.02\end{array}$ & $\begin{array}{l}<0.05 \\
<0.02\end{array}$ & $\begin{array}{l}<0.05 \\
<0.02\end{array}$ & $\begin{array}{l}<0.05 \\
0.055\end{array}$ & $\begin{array}{r}<0.05 \\
<0.020\end{array}$ & $\begin{array}{l}<0.05 \\
0.029\end{array}$ \\
\hline $\mathrm{Co}_{0}$ & & $<0.2$ & 0.02 & $<0.03$ & $<0.04$ & $<0.03$ & $<0.04$ & $<0.03$ & 0.04 & 0.04 & $<0.02$ \\
\hline Ni & & $<0.2$ & $<0.04$ & $<0.03$ & $<0.04$ & $<0.03$ & $<0.03$ & $<0.02$ & 0.03 & $<0.03$ & $<0.02$ \\
\hline $\begin{array}{l}\text { Cu } \\
\text { Zn } \\
\text { As }\end{array}$ & $\begin{array}{l}(I C P) \\
(I C P) \\
(A A)\end{array}$ & $\begin{array}{r}0.16 \\
0.13 \\
\overline{-} \\
<0.05\end{array}$ & $\begin{array}{r}<0.07 \\
0.07 \\
0.12 \\
<0.02\end{array}$ & $\begin{array}{r}<0.05 \\
0.09 \\
0.21 \\
<0.02\end{array}$ & $\begin{array}{r}<0.07 \\
0.07 \\
0.22 \\
<0.02\end{array}$ & $\begin{array}{r}<0.07 \\
0.08 \\
0.17 \\
<0.02\end{array}$ & $\begin{array}{r}<0.07 \\
0.09 \\
0.23 \\
<0.02\end{array}$ & $\begin{array}{r}<0.07 \\
0.04 \\
0.16 \\
<0.02\end{array}$ & $\begin{array}{r}<0.07 \\
0.06 \\
0.21 \\
<0.02\end{array}$ & $\begin{array}{r}<0.07 \\
0.09 \\
0.22 \\
<0.02\end{array}$ & $\begin{array}{r}<0.07 \\
0.05 \\
0.11 \\
<0.02\end{array}$ \\
\hline Se & & 0.02 & 0.014 & 0.044 & 0.017 & 0.014 & $<0.01$ & $<0.01$ & $<0.01$ & $<0.01$ & $<0.01$ \\
\hline $\mathrm{Br}$ & & 2.2 & 2.0 & 2.0 & 2.0 & 2.0 & 2.0 & 2.0 & 2.0 & 2.0 & 2.0 \\
\hline Sr & & 5.8 & 4.8 & 12.9 & 6.8 & 6.7 & 6.7 & 6.6 & 6.6 & 6.6 & 6.6 \\
\hline Mo & & 0.01 & 0.02 & 0.18 & 0.05 & 0.03 & 0.04 & 0.03 & 0.04 & 0.04 & 0.02 \\
\hline $\mathrm{cd}$ & & $<0.04$ & 0.006 & 0.013 & 0.026 & 0.009 & 0.011 & 0.007 & 0.009 & 0.009 & 0.006 \\
\hline So & & 0.05 & 0.03 & 0.06 & 0.15 & 0.09 & 0.12 & 0.07 & 0.11 & 0.15 & $<0.05$ \\
\hline $\mathrm{Ba}$ & . & 0.024 & 0.013 & 0.079 & 0.09 & 0.08 & 0.08 & 0.02 & 0.03 & 0.03 & 0.02 \\
\hline La & & $<0.8$ & 0.20 & 0.13 & 0.22 & 0.23 & 0.24 & 0.21 & 0.22 & 0.24 & 0.20 \\
\hline $\mathrm{Pb}$ & $\begin{array}{l}(\mathrm{ICP}) \\
(\mathrm{AA})\end{array}$ & $<0 . \overline{0}$ & $\begin{array}{r}0.16 \\
<0.02\end{array}$ & $\begin{array}{r}0.31 \\
<0.02\end{array}$ & $\begin{array}{r}0.33 \\
<0.02\end{array}$ & $\begin{array}{r}0.24 \\
<0.02\end{array}$ & $\begin{array}{r}0.30 \\
<0.02\end{array}$ & $\begin{array}{r}0.21 \\
<0.02\end{array}$ & $\begin{array}{r}0.27 \\
<0.02\end{array}$ & $\begin{array}{r}0.33 \\
<0.02\end{array}$ & $\begin{array}{r}0.14 \\
<0.02\end{array}$ \\
\hline U & & 54.4 & 53.4 & 3.6 & 36.0 & 52.6 & 56.2 & 55.2 & 54.4 & 51.0 & 40.4 \\
\hline $\mathrm{pH}$ & & 7.9 & 8.3 & - & 8.2 & 7.8 & -- & $=\quad \cdots$ & -. & 7.8 & 7.8 \\
\hline $\mathrm{HCO}_{2}$ & & 634 & - & 83.2 & - & - & - & $\cdots$ & - & -- & -- \\
\hline En & $(m V)$ & +330 & +256 & - & -- & -- & -. & -- & $=$ & +263 & +283 \\
\hline & tionucl & & & & & & & & & & \\
\hline $228 \mathrm{f}$ & & - & 169 & 38.2 & 2.8 & 0 & 0 & 0 & 0 & 0 & 0 \\
\hline
\end{tabular}

-. = Not Analyzed 
TABLE B.2.1. Series 2 Column 1 Effluent Composition (concentration units are ppm unless otherwise noted)

\begin{tabular}{|c|c|c|c|c|c|c|c|c|c|c|c|c|c|c|c|c|c|c|c|}
\hline ID. & $G M-2$ & $1-1$ & $1-2$ & $1-3$ & $1-4$ & $1-5$ & $1-8$ & $1-7$ & $1-8$ & $1-9$ & $1-10$ & $1=11$ & $1-12$ & $1-13$ & $1-14$ & $1-15$ & $1-16$ & $1-17$ & $1-18$ \\
\hline Ettluent (pore volumes) & - & 0.09 & 0.28 & 0.46 & 0.64 & 0.83 & 1.01 & 1.19 & 1.30 & 1.56 & 1.75 & 1.93 & 2.11 & 2.30 & 2.48 & 2.67 & 2.85 & 3.03 & 3.22 \\
\hline Tomereture $\left({ }^{\circ} \mathrm{C}\right)$ & 28 & 28 & 28 & 28 & 28 & 28 & 28 & 28 & 28 & 28 & 28 & 28 & 28 & 28 & 28 & 28 & 28 & 20 & 28 \\
\hline N1 & 0.4 & 8.8 & 8.6 & 0.9 & 8.6 & 9.0 & 8.9 & 9.0 & 0.9 & 8.9 & 6.9 & 9.0 & 9.0 & 9.0 & 9.0 & 9.1 & 9.1 & 9.1 & 9.1 \\
\hline en (mV) & +580 & N.D. & N.D. & N.D. & N.D. & N.D. & N.D. & W.D. & N.O. & N.D. & N.D. & N.D. & N.O. & N.D. & N.O. & N.D. & N.O. & N.O. & N.O \\
\hline Alkellalty $\left(\mathrm{mg} / \infty_{3}\right.$ ) & 120 & 33.6 & 69.3 & 94.2 & 90.3 & 101 & 106 & 113 & 115 & 118 & 120 & 118 & 118 & 115 & 105 & 120 & 120 & 120 & 120 \\
\hline ca & 13 & 100 & 74 & 51 & 45 & 37 & 31 & 26 & 23 & 20 & 20 & 19.9 & 20 & 25 & 35 & 18 & 19 & 19 & 19 \\
\hline$\omega_{0}$ & 4.9 & 37 & 30.1 & 21.4 & 18.1 & 15 & 12.7 & 10.9 & 9.55 & 9.12 & 8.66 & 6.54 & 8.43 & 9.49 & 12.6 & 8.2 & 0.1 & 8.0 & 8.0 \\
\hline Na & 360 & 740 & 690 & 1000 & 540 & 510 & 460 & 460 & 420 & 430 & 430 & 430 & 420 & 430 & 460 & 400 & 400 & 380 & 390 \\
\hline$x$ & 20 & 52 & 26 & 28 & 150 & 26 & $\mu$ & 20 & 20 & 16 & 16 & 23 & 15 & 15 & 15 & 14 & 21 & 13 & is \\
\hline CI & 430 & 442 & 446 & 478 & 553 & 452 & 462 & 458 & 433 & 436 & 430 & 426 & 423 & 423 & 455 & 429 & 436 & 423 & 420 \\
\hline $\mathrm{SO}_{4}$ & 73 & 1270 & 923 & 577 & 462 & 346 & 262 & 185 & 131 & 108 & 92 & $n$ & 77 & 100 & 215 & 69 & 62 & 69 & 62 \\
\hline Fo. $\begin{array}{c}100 \\
A A\end{array}$ & $\begin{array}{r}\text { N.O. } \\
<0.010\end{array}$ & $\begin{array}{r}(0.006) \\
<0.010\end{array}$ & $\begin{array}{r}0.121 \\
(0.010)\end{array}$ & $\begin{array}{l}<0.005 \\
<0.010\end{array}$ & $\begin{array}{r}0.005 \\
0.019\end{array}$ & $\begin{array}{l}<0.005 \\
<0.010\end{array}$ & $\begin{array}{l}0.012 \\
0.064\end{array}$ & $\begin{array}{r}0.009 \\
<0.010\end{array}$ & $\begin{array}{l}0.234 \\
0.012\end{array}$ & $\begin{array}{r}<0.005 \\
\times 0.010\end{array}$ & $\begin{array}{l}<0.005 \\
<0.010\end{array}$ & $\begin{array}{l}<0.005 \\
<0.010\end{array}$ & $\begin{array}{r}<0.005 \\
0.030\end{array}$ & $\begin{array}{l}<0.005 \\
<0.010\end{array}$ & $\begin{array}{r}0.01 \\
0.025\end{array}$ & $\begin{array}{r}0.027 \\
(0.010)\end{array}$ & $\begin{array}{r}0.016 \\
10.0101\end{array}$ & $\begin{array}{l}<0.005 \\
<0.010\end{array}$ & $\begin{array}{l}<0.005 \\
<0.010\end{array}$ \\
\hline $\mathrm{PO}_{4}$ & $<0.3$ & $<0.3$ & 0.3 & $<0.3$ & $<0.3$ & $<0.3$ & 6.9 & $<0.3$ & $<0.3$ & $<0.3$ & $<0.3$ & $<0.3$ & $<0.3$ & $<0.3$ & $<0.3$ & $<0.3$ & $<0.3$ & $<0.3$ & $<0.3$ \\
\hline A1 100 & $\begin{array}{r}<0.003 \\
0.018\end{array}$ & $\begin{array}{l}(0.040) \\
<0.020\end{array}$ & $\begin{array}{l}(0.034) \\
<0.020\end{array}$ & $\begin{array}{l}<0.03 \\
0.011\end{array}$ & $\begin{array}{l}(0.04) \\
<0.020\end{array}$ & $\begin{array}{r}(0.04) \\
0.033\end{array}$ & $\begin{array}{r}<0.03 \\
<0.020\end{array}$ & $\begin{array}{r}<0.0 \\
<0.020\end{array}$ & $\begin{array}{r}\omega .0 \\
<0.020\end{array}$ & $\begin{array}{r}(0.03) \\
0.023\end{array}$ & $\begin{array}{l}<0.03 \\
0.015\end{array}$ & $\begin{array}{l}<0.03 \\
0.011\end{array}$ & $\begin{array}{r}<0.03 \\
<0.010\end{array}$ & $\begin{array}{l}<0.03 \\
0.014\end{array}$ & $\begin{array}{l}0.047 \\
0.016\end{array}$ & $\begin{array}{l}<0.03 \\
0.012\end{array}$ & $\begin{array}{l}<0.03 \\
0.015\end{array}$ & $\begin{array}{r}<0.03 \\
<0.010\end{array}$ & $\begin{array}{l}<0.03 \\
0.019\end{array}$ \\
\hline 4 & $0 . \infty$ & 0.149 & $0.1 \times 6$ & 0.117 & 0.105 & 0.063 & 0.081 & 0.074 & 0.074 & 0.074 & 0.074 & 0.074 & 0.074 & 0.074 & 0.074 & 0.071 & 0.071 & 0.077 & 0.072 \\
\hline co & $<0.004$ & $<0.004$ & $<0.004$ & $<0.004$ & $<0.004$ & $<0.004$ & $<0.004$ & $<0.004$ & $<0.004$ & $<0.004$ & $<0.004$ & $<0.004$ & $<0,004$ & $<0.004$ & $<0.004$ & $<0.004$ & $<0.004$ & $<0.004$ & $<0.004$ \\
\hline st & 0.40 & 2,87 & 2.20 & 1.57 & 1.35 & 1.12 & 0.937 & 0.006 & 0.701 & 0.656 & 0.626 & 0.617 & 0.610 & 0.695 & 0.932 & 0.611 & 0.588 & 0.579 & 0.580 \\
\hline Ba & 0.069 & 0.076 & 0.066 & 0.076 & 0.079 & 0.120 & 0.134 & 0.140 & 0.129 & 0.191 & 0.206 & 0.189 & 0.173 & 0.151 & 0.120 & 0.171 & 0.142 & 0.155 & 0.157 \\
\hline m & $(0.005)$ & 0.027 & 0.016 & 0.012 & $<0.002$ & $(0.008 \mathrm{~J}$ & $(0.004)$ & $(0.006)$ & $(0.007)$ & $(0.004)$ & $(0.006)$ & $(0.005)$ & $(0.008)$ & 0.009 & 0.009 & $(0.004)$ & 0.006 & 0.006 & 0.006 \\
\hline cr & $<0.02$ & $<0.02$ & $<0.02$ & $<0.02$ & $<0.02$ & $<0,02$ & $<0.02$ & $<0.02$ & $<0.02$ & $<0.02$ & $<0.02$ & $<0.02$ & $<0.02$ & $<0.02$ & $<0.02$ & $<0.02$ & $<0.02$ & $<0,02$ & $<0.02$ \\
\hline$c_{0}$ & $<0.01$ & 0.01 & $<0.01$ & $<0.01$ & $\infty .01$ & $\infty .01$ & $\infty .01$ & $<0.01$ & $<0.01$ & $<0.01$ & $<0.01$ & $<0.01$ & $<0.01$ & $<0.01$ & $<0.01$ & $<0.01$ & $<0.01$ & $<0.01$ & $\infty .01$ \\
\hline NI & $<0.02$ & $<0.02$ & $<0.02$ & $<0.02$ & $<0.02$ & $<0.02$ & $<0.02$ & $<0.02$ & $<0.02$ & $<0.02$ & $<0.02$ & $<0.02$ & $<0.02$ & $<0.02$ & $<0.02$ & $(0.02)$ & $<0.02$ & $<0.02$ & $<0.02$ \\
\hline Cu & $<0.004$ & $(0.011)$ & 0.016 & $(0.009)$ & $(0.009)$ & $(0.009)$ & 0.015 & $(0,006)$ & 0.009 & $(0.006)$ & $(0.005)$ & $(0.005)$ & $(0.005)$ & $(0.005)$ & 0.006 & 0.026 & $<0.004$ & $<0.004$ & $<0.004$ \\
\hline $2 n$ & $<0.02$ & $<0.02$ & $<0,02$ & 0.023 & $(0.021)$ & $<0.02$ & $<0.02$ & $<0.02$ & $<0.02$ & $<0.02$ & $<0.02$ & $<0.02$ & $<0.02$ & $<0.02$ & $<0.02$ & 0.027 & $<0.02$ & $<0.02$ & $<0.02$ \\
\hline Pb & $<0.06$ & $<0.06$ & $<0 . \infty$ & 80.06 & $<0.06$ & $<0.06$ & $<0.06$ & $<0.06$ & $<0.06$ & $<0.06$ & $<0.06$ & $<0.06$ & $<0.06$ & $<0.06$ & $<0.06$ & $<0,06$ & $<0.06$ & $<0.06$ & $<0.06$ \\
\hline $\mathrm{H}_{4} \mathrm{SiO}_{4}$ & 29 & 18.1 & 19.1 & 23.0 & 19.3 & 21.8 & 22.4 & 22.1 & 21.3 & 22.5 & 22.5 & 21.4 & 20.8 & 20.6 & 22.0 & 21.3 & 21.4 & 20.6 & 20.4 \\
\hline $\mathrm{H}_{3} \mathrm{EO}_{3}$ & 5.7 & 4.50 & 4.74 & 3.55 & 4.92 & 6.01 & 6.48 & 6.46 & 6.18 & 6.75 & 6.73 & 6.35 & 6.12 & 6.06 & 6.46 & 6.46 & 6.35 & 6.23 & 6.12 \\
\hline As & $<0.015$ & 20.015 & $<0.015$ & 00.015 & $\infty 0.015$ & $<0.015$ & $<0.015$ & $<0.015$ & $<0.015$ & $<0.015$ & $<0.019$ & $<0.015$ & $<0.019$ & $<0.015$ & $<0.015$ & $<0.015$ & $<0,013$ & $<0.015$ & $<0.015$ \\
\hline u & 0.03 & 0.030 & 0.008 & 0.10 & 0.05 & 0.10 & 0.09 & 0.06 & 0.095 & 0.036 & 0.039 & 0.025 & 0.018 & 0.017 & 0.055 & 0.03 & 0.021 & 0.028 & 0.010 \\
\hline$v$ & $<0.020$ & $<0.020$ & $<0.020$ & $<0.020$ & $<0.020$ & $<0.020$ & $<0.020$ & $<0.020$ & $<0.020$ & $<0.020$ & $<0.020$ & $<0.020$ & $<0.020$ & $<0.020$ & $<0.020$ & $<0,020$ & $<0.020$ & $<0.020$ & $<0.020$ \\
\hline$m$ & $(0.01)$ & 0.33 & 0.25 & 0.16 & 0.14 & 0.11 & 0.096 & 0.067 & 0.056 & 0.044 & 0.034 & $(0.029)$ & $(0.023)$ & 0.035 & 0.066 & 0.043 & $(0.02)$ & $(0.017)$ & $(0.01)$ \\
\hline
\end{tabular}


TABLE B.2.2. Series 2 Column 2 Effluent Composition (concentration units are $\mathrm{ppm}$ unless otherwise noted)

\begin{tabular}{|c|c|c|c|c|c|c|c|c|c|c|c|c|c|c|c|c|c|c|c|}
\hline 1.D. & $L-1$ & $L-2$ & $\leq-3$ & $1-4$ & $2-1$ & $2-2$. & $2-3$ & $2-4$ & 2-5 & $2=6$ & $2-7$ & $2-8$ & $z-9$ & $2-10$ & $2-11$ & $2-12$ & $2-13$ & $2-14$ & $2=13$ \\
\hline Etfluent (pore volumes) & - & - & -- & - & 0.06 & 0.25 & 0.42 & 0.59 & 0.76 & 0.92 & 1.09 & 1.26 & 1.43 & 1.59 & 1.76 & 1.93 & 2.10 & 2.27 & 2.43 \\
\hline Temperature $\left({ }^{\circ} \mathrm{C}\right)$ & 28 & 20 & 25 & 25 & 28 & 28 & 28 & 20 & 28 & 28 & 20 & 28 & 28 & 28 & 28 & 28 & 28 & 28 & 28 \\
\hline DH & 8.0 & 8.0 & 8.1 & 8.0 & 7.5 & 7.5 & 7.5 & 7.5 & 7.5 & 7.9 & 7.5 & 7.5 & 7.5 & 7.5 & 7.6 & 1.6 & 7.6 & 7.6 & 7.6 \\
\hline En $(a v)$ & +190 & +240 & +350 & N.O. & +300 & +300 & +300 & +260 & +220 & +180 & +140 & +100 & +60 & +20 & 0 & -100 & -120 & -210 & -250 \\
\hline pe & 3.2 & 4.0 & 5.9 & N.D. & 5.0 & 5.0 & 5.0 & 4.4 & 3.7 & 3.0 & 2.3 & 1.7 & 1.0 & 0.3 & 0 & -1.7 & -2.0 & -3.5 & -4.2 \\
\hline Alkalinity $\left(\omega_{0} \wedge \mathrm{CO}_{3}\right)$ & N.D. & 204 & 251 & 222 & 64 & 65 & 76 & 91 & 120 & 133 & 147 & 120 & 139 & 120 & 147 & 139 & 131 & (4) & 92 \\
\hline$\infty$ & 250 & 220 & 230 & 225 & 140 & 130 & 150 & 170 & 195 & 210 & 220 & 230 & 230 & 240 & 230 & 230 & 230 & 220 & 220 \\
\hline w & 67 & แos & 86 & 86 & 32 & 53 & 60 & 69 & $n$ & 82 & 86 & 90 & 91 & 97 & 93 & 95 & 90 & 92 & 91 \\
\hline No & 1000 & 1000 & 940 & 940 & 810 & 780 & 830 & 890 & 940 & 980 & 1000 & 1070 & 1070 & 1100 & 1140 & 1200 & 1100 & 1200 & 1100 \\
\hline k & 30 & 42 & 32 & 32 & 330 & 140 & 58 & 40 & 43 & 30 & 48 & so & 52 & 52 & 57 & 54 & 54 & 63 & 63 \\
\hline cI & 1080 & 1010 & 1010 & 1020 & 943 & 683 & 748 & 078 & 1000 & 1106 & 1130 & 1130 & 1106 & 1236 & 1170 & 1138 & 1106 & 1150 & 1138 \\
\hline $\mathrm{so}_{4}$ & 1333 & 1530 & 1570 & 1570 & 1518 & 1482 & 1518 & 1482 & 1482 & 1482 & 1510 & 1510 & 1482 & 1482 & 1518 & 1518 & 1482 & 1318 & 1518 \\
\hline Fo. ${ }_{M}$ & $\begin{array}{r}<0.005 \\
0.015\end{array}$ & $\begin{array}{l}(0.06) \\
<0.010\end{array}$ & $\begin{array}{r}0.03 \\
<0.010\end{array}$ & $\begin{array}{l}<0.015 \\
<0.010\end{array}$ & $\begin{array}{r}(0.007) \\
0.022\end{array}$ & $\begin{array}{r}(0.006) \\
0.015\end{array}$ & $\begin{array}{l}<0.005 \\
0.023\end{array}$ & $\begin{array}{r}<0,005 \\
0.014\end{array}$ & $\begin{array}{l}<0.005 \\
<0.020\end{array}$ & $\begin{array}{l}<0.01 \\
0.011\end{array}$ & $\begin{array}{l}<0.01 \\
0.003\end{array}$ & $\begin{array}{l}<0.01 \\
0.007\end{array}$ & $\begin{array}{l}<0.01 \\
0.005\end{array}$ & $\begin{array}{r}0.06 \\
0.030\end{array}$ & $\begin{array}{l}<0.01 \\
0.022\end{array}$ & $\begin{array}{r}<0.01 \\
<0.010\end{array}$ & $\begin{array}{r}<0.01 \\
80.010\end{array}$ & $\begin{array}{l}<0.01 \\
<0.010\end{array}$ & $\begin{array}{r}<0.01 \\
<0.010\end{array}$ \\
\hline $\mathrm{PO}_{4}$ & 10.61 & $<0.9$ & (2) & $(0.9)$ & 1.2 & 4.9 & 0.6 & $<0.3$ & $<0.3$ & $<0.3$ & $<0,3$ & $<0.3$ & $<0.3$ & $<0.3$ & $\infty .3$ & $<0.3$ & $<0.3$ & $<0.3$ & $<0.3$ \\
\hline AI ${ }_{M}^{\prime O}$ & $\begin{array}{l}<0.03 \\
0.033\end{array}$ & $\begin{array}{r}<0.09 \\
<0.010\end{array}$ & $\begin{array}{l}<0.09 \\
0.011\end{array}$ & $\begin{array}{r}<0.09 \\
<0.010\end{array}$ & $\begin{array}{l}<0.03 \\
0.032\end{array}$ & $\begin{array}{r}<0.03 \\
<0.023\end{array}$ & $\begin{array}{r}<0.03 \\
<0.025\end{array}$ & $\begin{array}{r}<0.03 \\
<0.030\end{array}$ & $\begin{array}{r}<0.03 \\
<0.020\end{array}$ & $\begin{array}{r}<0.06 \\
<0.020\end{array}$ & $\begin{array}{r}<0.08 \\
<0.020\end{array}$ & $\begin{array}{r}<0.06 \\
<0.020\end{array}$ & $\begin{array}{r}<0.06 \\
<0.020\end{array}$ & $\begin{array}{l}<0.06 \\
0.093\end{array}$ & $\begin{array}{r}<0.06 \\
<0.020\end{array}$ & $\begin{array}{r}<0.06 \\
<0.020\end{array}$ & $\begin{array}{r}<0.06 \\
<0.020\end{array}$ & $\begin{array}{l}20.08 \\
0.010\end{array}$ & $\begin{array}{l}<0.06 \\
0.010\end{array}$ \\
\hline Br & 2.3 & 2.0 & 1.8 & 2.0 & 2.5 & 2.3 & 2.5 & 2.5 & 2.7 & 2.5 & 2.9 & 2.7 & 2.6 & 2.6 & 2.7 & 2.3 & 2.7 & 2.3 & 2.5 \\
\hline Co & $(0.018)$ & 6.012 & $<0.012$ & $\infty .012$ & 0.026 & 0.01 & $(0.004)$ & $(0.005)$ & $(0,006)$ & $(0.01)$ & 0.01 & $(0.01)$ & $(0.01)$ & 10.01 & $<0.01$ & $<0.01$ & 0.01 & 80.01 & $\infty .01$ \\
\hline sr & 5.0 & 3.) & 5.6 & 9.7 & 4.13 & 4.11 & 4.60 & 3.36 & 6 & 6.3 & 6.5 & 6.0 & 6.5 & 7.3 & 1.0 & 1.2 & 6.9 & 6.9 & 6.9 \\
\hline an & 0.02 & 0.018 & 0.021 & 0.021 & 0.023 & 0.032 & 0.019 & 0.026 & 0.025 & 0.068 & 0.066 & 0.092 & 0.086 & 0.082 & 0.11 & 0.092 & 0.094 & 0.10 & 0.088 \\
\hline$m$ & $(0.01)$ & 0.024 & 0.03 & 0.03 & 0.027 & 0.024 & 0.033 & 0.040 & 0.046 & 0.048 & 0.056 & 0.058 & 0.06 & 0.056 & 0.05 & 0.054 & 0.06 & 0.04 & 0.046 \\
\hline or & $<0.02$ & 40.06 & $<0.06$ & $<0.08$ & $(0.028)$ & $<0.02$ & $<0.02$ & 60.02 & 6.02 & $<0.04$ & $<0.04$ & $<0.04$ & $<0.04$ & 0.01 & $<0.04$ & $<0.04$ & $<0.04$ & $<0.04$ & $<0.04$ \\
\hline co & $<0.01$ & $<0.03$ & 0.03 & $<0.03$ & $<0.01$ & $<0.01$ & $<0.01$ & $(0.01)$ & $\{0.017\}$ & $(0.02)$ & $(0.03)$ & $<0.02$ & $<0.02$ & $<0.02$ & $<0.02$ & $<0.02$ & $<0.02$ & $<0.02$ & $<0.02$ \\
\hline NI & $<0.02$ & $<0.06$ & $<0.06$ & $<0.06$ & $(0,03)$ & $<0,02$ & $<0.02$ & $<0.02$ & $<0.02$ & $<0.04$ & $<0.04$ & $<0.04$ & $<0.04$ & $<0.04$ & $<0.04$ & $<0.04$ & $<0.04$ & $<0.04$ & $<0,04$ \\
\hline cu & $<0.004$ & $<0.012$ & $<0.012$ & $<0.012$ & $<0.004$ & $<0.004$ & $<0.004$ & $<0.004$ & $<0.004$ & $<0.008$ & $<0.008$ & $<0.000$ & $<.000$ & $<0.008$ & $<0.008$ & $<0.000$ & $<0.000$ & $<0.000$ & $<0.006$ \\
\hline $\mathrm{Zn}$ & $<0.02$ & $<0.06$ & $<0.06$ & $<0.06$ & $(0,038)$ & $\{0.027\}$ & 0.02 & $(0.02)$ & $(0.02)$ & 20.04 & $<0.04$ & 60.04 & $<0.04$ & $(0.04)$ & $<0.04$ & $<0.04$ & $<0.04$ & $<0,04$ & $<0.04$ \\
\hline PD & $<0.06$ & $\$ 0.18$ & $(0.3)$ & $(0.3)$ & $<0.06$ & $<0.06$ & $<0.06$ & 20.06 & $<0.06$ & $<0.1$ & $<0.1$ & $<0.1$ & $<0.1$ & $<.1$ & $<0.1$ & $<0.1$ & 0.1 & $<0.1$ & $<0.1$ \\
\hline $\mathrm{H}_{4} \mathrm{SIO}_{4}$ & 32.9 & 32 & 32 & 31 & 20 & 16 & 19 & 21 & 22 & 22 & 26 & 27 & 28 & 31 & 31 & 31 & 30 & 30 & 30 \\
\hline $\mathrm{H}_{3} \mathrm{BO}_{3}$ & 9.1 & 0.0 & 8.0 & 0.0 & 5.07 & 4.79 & 5.3 & 6.29 & 6.9 & 7.4 & 8.0 & 8.0 & 8.0 & 9.2 & 9.3 & 9.4 & 8.8 & 9.2 & 9.2 \\
\hline As & $<0.015$ & $<0.015$ & $<0.013$ & 0.015 & $<0.015$ & $<0,015$ & 4.013 & $<0.015$ & $<0.015$ & 0.015 & $<0.015$ & $<0.015$ & $<0.015$ & $<0.015$ & $<0.015$ & $<0.015$ & $<0,015$ & $<0.015$ & 0.015 \\
\hline u & 56 & 95 & 43,6 & 52.3 & 0.11 & 1.5 & 3.25 & 12.5 & 17.2 & 23.9 & 27.8 & 30.4 & 35.2 & 30 & 35.9 & 20.8 & 20.0 & 14.5 & 14,2 \\
\hline$v$ & $<0.020$ & $<0.020$ & 0,020 & $<0.020$ & $<0.020$ & 0.020 & $<0.020$ & $<0,020$ & $<0.020$ & $<0.020$ & $<0.020$ & $<0.020$ & $\omega .020$ & $<0.020$ & $<0.020$ & $<0.020$ & $<0.020$ & $<0.020$ & $<0.020$ \\
\hline
\end{tabular}

N.D. - not antectod

(1) denotes questionable value near detection IImits 
TABLE B.2.2. (contd)

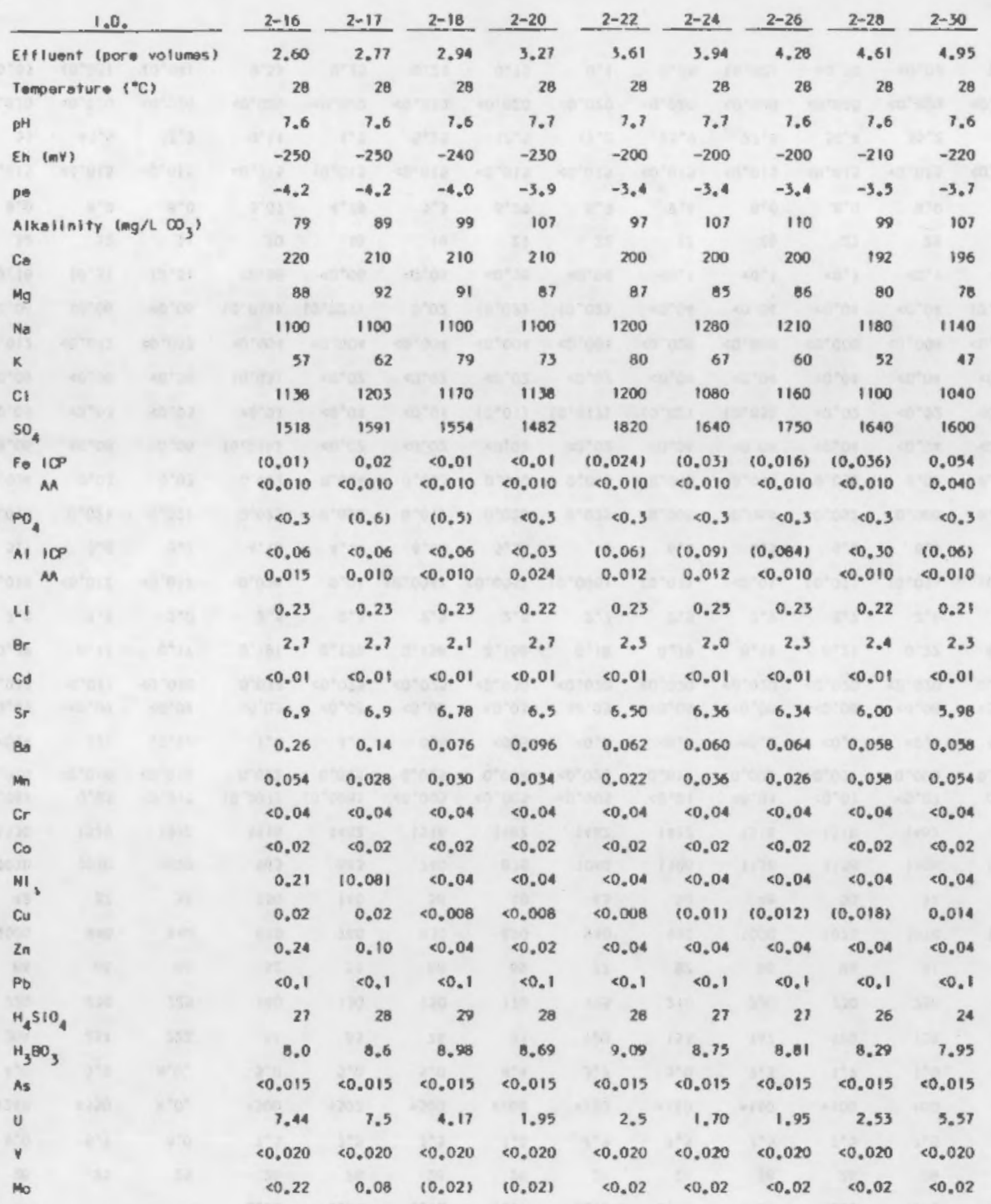


TABLE B.2.3. Series 2 Column 3 Effluent Composition (concentration units are ppm unless otherwise noted)

\begin{tabular}{|c|c|c|c|c|c|c|c|c|c|c|c|c|c|c|c|c|c|c|c|}
\hline $1,0_{2}$ & $9-1$ & $3-2$ & $3-3$ & $5-5$ & $3-6$ & $3-0$ & $3-10$ & $3-11$ & $3-13$ & $9-14$ & $3-16$ & $3-17$ & $3-19$ & $3-20$ & $3-22$ & $3-23$ & $5-25$ & $3-26$ & \\
\hline Eftluent (pare volumas) & & 0.04 & 0.11 & 0.10 & 0.32 & 0.39 & 0.53 & 0.67 & 0.74 & 0.89 & 0.96 & 1.10 & 1.17 & 1,31 & 1.30 & 1.52 & 1.60 & 1.74 & 1.81 \\
\hline Temperature $\left({ }^{\circ} \mathrm{C}\right\}$ & & 20 & 28 & 28 & 28 & 20 & 29 & 20 & 28 & 28 & 28 & 28 & 28 & 28 & 28 & 28 & 28 & 26. & 28 \\
\hline DH & & 7.9 & 7.9 & 2.9 & 7.9 & 7.8 & 7.8 & 1.0 & 7.8 & 7.6 & 7.6 & 7.8 & 7,0 & 7,8 & 1.8 & 7.8 & 7.6 & 7.8 & 7.7 \\
\hline En $(n V)$ & N.D, & N.D. & N.D. & N.D. & N.D. & +160 & N.D. & H.D. & W.D. & +110 & +90 & $+\infty 0$ & N.D. & N.D. & -260 & N.O. & -140 & N.o. & N,D. \\
\hline Alkallnity $\left(\mathrm{mg} / \mathrm{c} \infty_{3}\right)$ & & 69 & so & 52 & 36 & $\$$ & 84 & 63 & $n$ & 94 & 107 & 118 & 113 & 99 & 122 & 131 & 115 & 123 & 115 \\
\hline$c_{0}$ & & 390 & 340 & 340 & 310 & 310 & 276 & 300 & 290 & 230 & 270 & 270 & 270 & 268 & 270 & 274 & 246 & 244 & 254 \\
\hline$n_{0}$ & & 130 & 125 & 123 & 113 & 114 & 100 & 108 & 103 & 105 & 100 & 98 & 103 & 97 & 101 & 101 & 94 & 95 & 97 \\
\hline No & & 1100 & 1090 & 1000 & 1040 & 1140 & 1010 & 1010 & 1000 & 1100 & 1070 & 1020 & 1080 & 1000 & 1100 & 1100 & 980 & 1000 & 1030 \\
\hline k & & 210 & 120 & 75 & 36 & 60 & 56 & s5 & 57 & 62 & 54 & 50 & 50 & so & 63 & 55 & 45 & 49 & so \\
\hline $\mathrm{Cl}$ & & 625 & 531 & 500 & 503 & 625 & 906 & 750 & 780 & 1125 & 3125 & 1156 & 1188 & 1125 & 1156 & 1125 & 1180 & 1188 & 1188 \\
\hline so $_{4}$ & & 3300 & 3200 & 3133 & 2867 & 2667 & 2033 & 2500 & 2300 & 1835 & 1733 & 1600 & 1633 & 1500 & 1500 & 1466 & 1533 & 1500 & 1533 \\
\hline Fo $\underset{M A}{I O P}$ & & $\begin{array}{l}0.032 \\
0.026\end{array}$ & $\begin{array}{l}0.032 \\
0.018\end{array}$ & $\begin{array}{l}0.056 \\
0.022\end{array}$ & $\begin{array}{l}<0.01 \\
0.014\end{array}$ & $\begin{array}{l}20.01 \\
0.013\end{array}$ & $\begin{array}{l}<0.01 \\
0.002\end{array}$ & $\begin{array}{l}c 0.01 \\
0.010\end{array}$ & $\begin{array}{l}<0.01 \\
0.015\end{array}$ & $\begin{array}{r}(0,06) \\
0.036\end{array}$ & $\begin{array}{l}<0.01 \\
0.064\end{array}$ & $\begin{array}{r}<0.01 \\
<0.010\end{array}$ & $\begin{array}{r}<0,01 \\
<0.010\end{array}$ & $\begin{array}{r}<0.01 \\
<0.010\end{array}$ & $\begin{array}{l}<0.01 \\
0.010\end{array}$ & $\begin{array}{l}<0.01 \\
0.011\end{array}$ & $\begin{array}{r}<0.01 \\
<0.039\end{array}$ & $\begin{array}{r}<0.01 \\
<0.010\end{array}$ & $\begin{array}{r}<0.01 \\
<0.010\end{array}$ \\
\hline $\mathrm{PO}_{4}$ & & 1 & , & I & 1 & 0.6 & $<0.6$ & 80.6 & $<0.6$ & $<0.6$ & $<0.6$ & 1 & (1) & (1) & $<0.6$ & $<0.6$ & (1) & (1) & (1) \\
\hline AI ICP & & $\begin{array}{r}<0.06 \\
<0,020\end{array}$ & $\begin{array}{r}<0.06 \\
<0.025\end{array}$ & $\begin{array}{r}<0.06 \\
<0.020\end{array}$ & $\begin{array}{r}<0.06 \\
<0.020\end{array}$ & $\begin{array}{r}<0,06 \\
<0.020\end{array}$ & $\begin{array}{r}<0.06 \\
<0.020\end{array}$ & $\begin{array}{r}<0.06 \\
<0.020\end{array}$ & $\begin{array}{r}<0,06 \\
<0.020\end{array}$ & $\begin{array}{r}<0.06 \\
<0.020\end{array}$ & $\begin{array}{l}<0.06 \\
\infty .020\end{array}$ & $\begin{array}{r}<0.06 \\
<0.020\end{array}$ & $\begin{array}{r}<0.06 \\
<0.022\end{array}$ & $\begin{array}{r}<0,06 \\
<0,010\end{array}$ & $\begin{array}{l}<0.06 \\
0.013\end{array}$ & $\begin{array}{l}<0.06 \\
0.026\end{array}$ & $\begin{array}{l}e 0.06 \\
0.010\end{array}$ & $\begin{array}{r}<0.06 \\
\times 0.010\end{array}$ & $\begin{array}{l}<0.06 \\
0.011\end{array}$ \\
\hline 4 & & 0.250 & 0.242 & 0.23 & 0.23 & 0.26 & 0.22 & 0.22 & 0.22 & 0.24 & 0.23 & 0.37 & 0.25 & 0.22 & 0.25 & 0.24 & 0.20 & 0.20 & 0.22 \\
\hline Br & & 1.7 & 1.7 & 2.0 & 2.0 & 2.0 & 2.4 & 2.0 & 2.3 & 2.6 & 2.6 & 2.3 & "z & 2.4 & 2.4 & 2.4 & 2.0 & 2.4 & 2.6 \\
\hline Cd & & $(0.014)$ & $(0.012)$ & $(0.012)$ & $<0.008$ & $<0.008$ & $(0.012)$ & $(0,01)$ & 0.012 & 0.010 & 0.010 & 0.05 & 0.022 & 0.014 & 0.012 & 0.014 & 0.012 & 0.012 & 0.012 \\
\hline Sr & & 10.3 & 9.9 & 5.6 & 8.9 & 9.1 & 1.9 & 8.5 & 7.9 & 0.0 & 7.7 & 7.5 & 6.7 & 7.4 & 1.7 & 7.7 & 6.8 & 6.7 & 7.0 \\
\hline Bo & & 0.016 & 0.014 & 0.012 & 0.006 & $<0.004$ & 0.000 & 0.000 & 0.010 & 0.012 & 0.012 & 0.014 & 0.012 & 0.014 & 0.014 & 0.014 & 0.014 & 0.014 & 0.014 \\
\hline$M_{n}$ & & 0.16 & 0.15 & 0.15 & 0.12 & 0.12 & 0.11 & 0.12 & 0.12 & 0.10 & 0.10 & 0.20 & 0.00 & 0.12 & 0.12 & 0.13 & 0.090 & 0.086 & 0.10 \\
\hline cr & & $<0.04$ & $<0.04$ & $<0.04$ & $<0.04$ & 20.04 & $<0.04$ & $<0.04$ & $<0.04$ & $\infty .04$ & $<0.04$ & 0.11 & $<0.04$ & $<0.04$ & $<0.04$ & $<0.04$ & $<0.04$ & $<0.04$ & $<0.04$ \\
\hline$c_{0}$ & & $<0.02$ & $\infty .02$ & $<0.02$ & $<0.02$ & $<0.02$ & $<0.02$ & $<0.02$ & $<0.02$ & $<0.02$ & $<0.02$ & $<0.02$ & $<0.02$ & $(0.02)$ & $<0.02$ & 0.02 & $(0.02)$ & $(0.02)$ & $(0.02)$ \\
\hline IN & & $<0,04$ & $<0.04$ & $<0.04$ & $<0.04$ & $<0.04$ & $<0.04$ & $<0.04$ & $<0.04$ & $<0.04$ & $<0.04$ & $<0.04$ & $\infty .04$ & $<0.04$ & $<0.04$ & $<0.04$ & $<0.04$ & $<0.04$ & $<0.04$ \\
\hline $\mathrm{Cu}$ & & $<0.000$ & $<0.008$ & $<0,000$ & $<0,000$ & $<0.008$ & $<0.008$ & $<0.008$ & $<0.000$ & $<0.000$ & $<0,000$ & $<0.008$ & $<0.008$ & $<0.008$ & $<0.008$ & $<0.008$ & $<0.008$ & $<0.000$ & $<0.008$ \\
\hline $2 n$ & & 10.05 & $<0.04$ & $<0.04$ & $<0.04$ & $<0.00$ & $<0.04$ & $<0.04$ & $<0.04$ & $<0.04$ & $<0.04$ & $<0.04$ & $<0.04$ & $<0,04$ & $<0.04$ & $<0.04$ & $<0.04$ & $<0.04$ & $<0.04$ \\
\hline po & & $<0.1$ & $<0.1$ & $<0.1$ & $\infty .1$ & $<0.1$ & $\infty .1$ & $<0.1$ & $<0.1$ & $<0.1$ & $<0.1$ & $<0.1$ & $<0.1$ & $<0.1$ & $<0.1$ & $<0.1$ & $<0.1$ & $<0.1$ & $<0.1$ \\
\hline $\mathrm{H}_{4} \mathrm{SIO}_{4}$ & & 21 & 18 & 11 & 16 & 17 & 18 & 17 & 17 & 22 & 23 & 23 & 24 & 24 & 25 & 25 & 23 & 24 & 24 \\
\hline $\mathrm{H}_{3} \mathrm{EO}_{3}$ & & 4.6 & 4.7 & 4.7 & 4.7 & 5.0 & 9,03 & 3.2 & 5.4 & a. 0 & 8.0 & 9.2 & 9.04 & 8.87 & 9.27 & 9.2 & 6.6 & 8.6 & 8.98 \\
\hline As & & $<0.015$ & $<0.015$ & $<0.013$ & $<0.015$ & $<0.015$ & $<0.015$ & $<0.015$ & $<0.015$ & $<0.015$ & $<0.015$ & $<0.015$ & $<0.015$ & $<0.015$ & $<0.015$ & $<0.015$ & $<0.015$ & $e 0.015$ & $<0.015$ \\
\hline v & & 0.078 & 0.5 & 0.1 & 0.72 & 1.2 & 6.18 & 2.7 & 3.7 & 11.3 & 11.5 & 17.1 & 17.1 & 25.4 & 21.3 & 24.4 & 28.3 & 27.6 & 23.4 \\
\hline$v$ & & $<0.020$ & $<0.020$ & $<0.020$ & $<0.020$ & $<0.020$ & $<0.020$ & $<0.020$ & $<0.020$ & $<0,020$ & $<0.020$ & $<0.020$ & $<0.020$ & $<0.020$ & $<0.020$ & $<0.020$ & $<0.020$ & $<0.020$ & $<0.020$ \\
\hline Mo & & 0.12 & 0.12 & 0.12 & 0.09 & 0.00 & 0.07 & 0.08 & 0.07 & 0.04 & 0.04 & 0.04 & 0.04 & 0.04 & 0.03 & 0.03 & 0.04 & 0.03 & 0.04 \\
\hline
\end{tabular}

N.D. - not determined

(1) denotes questionabie value near detection $11 \mathrm{mit}$ 


\section{TABLE B.2.3. (contd)}

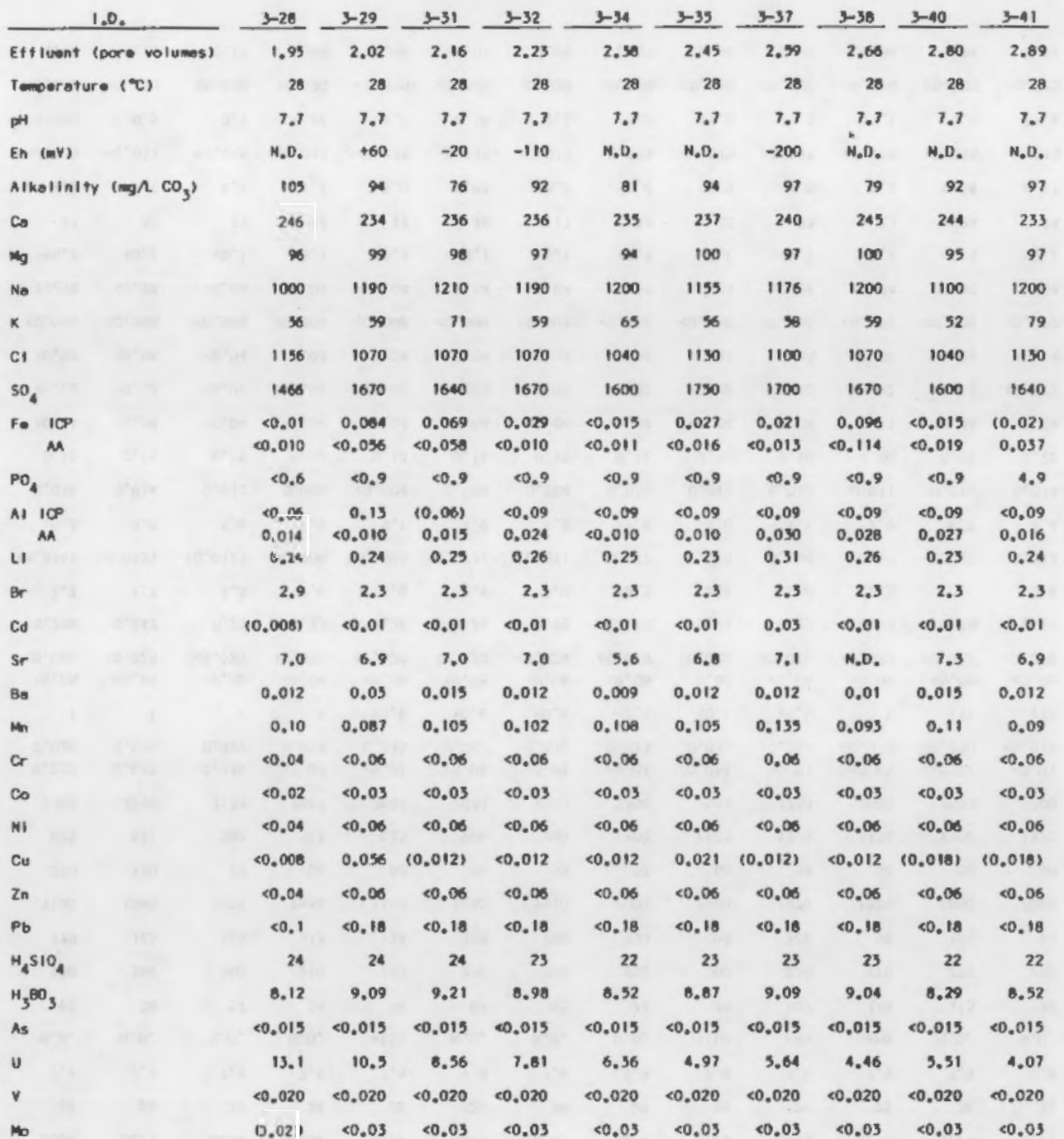


TABLE B.2.3. (contd)

$\frac{3-42}{2.90} \frac{3-44}{3.17} \frac{3-43}{3.24} \frac{3.46}{3.33} \frac{3-47}{3.41} \frac{3-50}{3.34} \frac{3-51}{3.63}-\frac{3-52}{3.71} \frac{3.54}{3.93} \frac{3-90}{4.10} \frac{3.57}{4.19} \frac{3-50}{4.20} \frac{3-99}{4.30} \frac{3-60}{4.46} \frac{3-62}{4.64}$

\begin{tabular}{|c|c|c|c|c|c|c|c|c|c|c|c|c|c|c|c|}
\hline & & & & & & & & & & & & & & & \\
\hline Effluent (pore volumes) & 2.96 & 3.17 & 3.24 & 3.33 & 3.41 & 3.34 & 3.63 & 3.71 & 3.93 & 4.10 & 4.19 & 4.26 & 4.50 & 4.46 & 4.64 \\
\hline Temperature $\left({ }^{n}\right)$ & 20 & 28 & 25 & 25 & 23 & 25 & 25 & 25 & 25 & 25 & 25 & 25 & 25 & 25 & 25 \\
\hline phr & 7.7 & 1.7 & 1.7 & 7.7 & 7.7 & 7.7 & 7.7 & 7.7 & 1.8 & 7.8 & 7.8 & 7.8 & 3.8 & 7.0 & 7.8 \\
\hline En $(n v)$ & N.O. & N.O. & N.D. & N.D. & N.D. & $-\infty$ & -220 & N.D. & N.D. & -260 & N.D. & N.O. & N.o. & -360 & N.O. \\
\hline Alkallnity $\left(\mathrm{mg} / \mathrm{C} \mathrm{Co}_{3}\right)$ & 139 & 94 & 110 & 99 & 110 & 120 & 130 & 120 & 139 & 147 & 147 & 187 & (4) & 139 & 144 \\
\hline co & 243 & 230 & 210 & 184 & 100 & 100 & 80 & 13 & 43 & 35 & 31 & 29 & 27 & 20 & 23 \\
\hline$\omega_{0}$ & 99 & 66 & 84 & 13 & 63 & 42 & M & 31 & 22 & 15 & 14 & 13 & 12 & 12 & 10 \\
\hline Na & 1200 & 1090 & 1000 & 1080 & 1000 & 840 & 740 & 200 & 610 & 560 & 510 & 490 & 520 & 470 & 440 \\
\hline k & 100 & 63 & 60 & 69 & 72 & 66 & 31 & 51 & 30 & 53 & 55 & 47 & 51 & 29 & 37 \\
\hline cI & 1040 & 1040 & 1020 & 930 & 830 & 700 & 640 & 630 & 580 & 500 & 500 & 460 & 460 & 460 & 430 \\
\hline $\mathrm{SO}_{4}$ & 1600 & 1600 & 1580 & 1300 & $11 \times 0$ & 690 & 300 & 510 & 360 & 220 & 180 & 100 & 150 & 150 & 110 \\
\hline Fo $\begin{array}{c}\text { ICP } \\
M A\end{array}$ & $\begin{array}{r}0.1 \\
0.006\end{array}$ & $\begin{array}{l}<0.015 \\
<0.010\end{array}$ & $\begin{array}{r}0.03 \\
0.021\end{array}$ & $\begin{array}{r}0.18 \\
0.010\end{array}$ & $\begin{array}{r}0.10 \\
0.033\end{array}$ & $\begin{array}{l}<0.01 \\
0.012\end{array}$ & $\begin{array}{r}<0.010 \\
0.014\end{array}$ & $\begin{array}{l}<0.01 \\
0.011\end{array}$ & $\begin{array}{r}<0.01 \\
<0,010\end{array}$ & $\begin{array}{r}0.11 \\
e 0.010\end{array}$ & $\begin{array}{l}<0.005 \\
<0.010\end{array}$ & $\begin{array}{l}<0.005 \\
\infty .010\end{array}$ & $\begin{array}{l}<0.005 \\
<0.010\end{array}$ & $\begin{array}{r}<0.005 \\
0.014\end{array}$ & $\begin{array}{r}0.02 \\
<0.010\end{array}$ \\
\hline $\mathrm{PO}_{4}$ & $(0.9)$ & $<0.9$ & $<0.9$ & $<0.9$ & $\infty .0$ & $<0.9$ & $<0.6$ & 0.6 & $<0.6$ & $<0.3$ & $<0.3$ & $\infty .3$ & $\infty .3$ & $<0.3$ & $\$ 0.3$ \\
\hline A1 $1 \mathbb{A O}^{\circ}$ & $\begin{array}{l}<0.09 \\
0.013\end{array}$ & $\begin{array}{l}<0.09 \\
0.096\end{array}$ & $\begin{array}{r}<0.00 \\
<0.010\end{array}$ & $\begin{array}{l}<0.09 \\
0.018\end{array}$ & $\begin{array}{r}\infty 0.09 \\
<0.010\end{array}$ & $\begin{array}{l}<0.09 \\
0.012\end{array}$ & $\begin{array}{l}<0.09 \\
0.010\end{array}$ & $\begin{array}{l}<0.06 \\
0.015\end{array}$ & $\begin{array}{l}(0.07) \\
00.010\end{array}$ & $\begin{array}{r}0.05 \\
0.012\end{array}$ & $\begin{array}{r}0.04 \\
<0.010\end{array}$ & $\begin{array}{l}\infty .03 \\
0.011\end{array}$ & $\begin{array}{l}0.03 \\
0.011\end{array}$ & $\begin{array}{l}<0.03 \\
0.024\end{array}$ & $\begin{array}{l}<0.03 \\
0.012\end{array}$ \\
\hline$u$ & 0.26 & 0.22 & 0.21 & 0.22 & 0.20 & 0.15 & 0.14 & 0.14 & 0.12 & 0.12 & 0.10 & 0.096 & 0.099 & 0.000 & 0.079 \\
\hline$\theta$ & 2.3 & 2.3 & 2.3 & 2.3 & 2.1 & 2.4 & 2.1 & 1.0 & 2.0 & 1.8 & 1.5 & 1.5 & 1.8 & 2.0 & 1.5 \\
\hline co & $<0,01$ & $<0.01$ & $\infty .01$ & $<0.01$ & $\$ 0.01$ & $<0.01$ & 0.008 & $<0.008$ & $<0,000$ & 0.009 & $<0.004$ & $<0.004$ & $<0,004$ & $<0.004$ & $<0.004$ \\
\hline Sr & 3.3 & 6.7 & 6.0 & 5,3 & 4.3 & 3.0 & 2.3 & 2.3 & 1.5 & 1.1 & 1.0 & 0.95 & 0.91 & 0.76 & 0.75 \\
\hline Bo & 0.012 & 0.015 & 0.012 & $(0.009)$ & $(0.009)$ & $<0.006$ & 0.014 & 0.016 & 0.016 & 0.028 & 0.03 & 0.03 & 0.036 & 0.034 & 0.047 \\
\hline m & 0.11 & $0.09 \%$ & 0.06 & 0.05 & $(0,015)$ & $(0.015)$ & $(0.012)$ & 0.01 & $<0,004$ & 0.01 & $<0.002$ & $<0.002$ & $<0.002$ & $<0.002$ & $<0.002$ \\
\hline cr & $<0,06$ & 80.06 & $<0.08$ & $<0,06$ & $<0,06$ & $<0.06$ & $<0.04$ & $<0.04$ & $<0.04$ & $<0.02$ & $<0,02$ & $<0.02$ & $<0.02$ & $<0.02$ & $<0.02$ \\
\hline$c_{0}$ & $<0.03$ & 0.03 & $<0.03$ & $<0.03$ & $<0.03$ & $<0.03$ & $<0.02$ & $<0,02$ & $<0.02$ & $<0.01$ & $<0.01$ & $\infty .01$ & $<0.01$ & $<0,01$ & $<0.01$ \\
\hline NI & $<0.08$ & $<0.06$ & $<0.06$ & $<0.08$ & $<0.08$ & $<0.06$ & $<0.04$ & $<0,04$ & $<0,04$ & $<0,02$ & $<0.02$ & $<0.02$ & $<0,02$ & $<0.02$ & $<0.02$ \\
\hline cu & $(0.02)$ & $<0.012$ & $(0.018)$ & $(0.015)$ & 0.01 & $<0.012$ & $<0,000$ & $<0,000$ & $<0,006$ & $<0.004$ & $<0,004$ & $<0.004$ & $<0.004$ & $<0.004$ & $<0.004$ \\
\hline$Z n$ & $<0.06$ & $<0.08$ & $<0.06$ & $<0.06$ & $<0.06$ & $<0.06$ & $<0.04$ & $<0,04$ & $<0.04$ & $<0.02$ & $<0.02$ & $<0.02$ & $<0.02$ & $<0.02$ & $<0.02$ \\
\hline $\mathrm{Pb}_{\mathrm{b}}$ & $<0.18$ & $<0,18$ & $<0.18$ & $<0.18$ & $<0.18$ & $<0.10$ & $<0.12$ & $<0,12$ & $<0.12$ & $<0.06$ & $<0.06$ & $<0.06$ & $<0.06$ & $<0.06$ & 0.06 \\
\hline $\mathrm{H}_{4} \mathrm{SiO}_{4}$ & 22 & 20 & 20 & 21 & 20 & 20 & 19 & 19 & 18 & 17 & 17 & 16 & $n$ & 16 & $n$ \\
\hline $\mathrm{H}_{3} \mathrm{BO}_{3}$ & 8.18 & 7.38 & 7.55 & 7.61 & 7.44 & 6.86 & 6.18 & 6.3 & 5.7 & 3.4 & 5.2 & 5.1 & 5.4 & 3.3 & 5.4 \\
\hline u & 3.90 & 4.97 & 6.10 & 6.0 & 3.26 & 5.04 & 3.72 & 3.49 & 2.39 & 1,70 & 1.16 & 1.67 & 0.6 & 0.61 & 0.34 \\
\hline$v$ & $<0.020$ & $<0.020$ & $<0.020$ & $<0.020$ & $<0.020$ & $<0.020$ & $<0.020$ & $<0.020$ & $<0.020$ & $<0.020$ & $<0.020$ & $<0.020$ & $<0.020$ & $<0.020$ & $<0.020$ \\
\hline No & $<0.03$ & $<0.03$ & $<0.03$ & $<0.03$ & $<0.03$ & $<0.03$ & $(0.02)$ & $(0.02)$ & $(0.03)$ & 0.02 & 0.03 & 0.02 & 0.024 & 0.027 & 0.024 \\
\hline
\end{tabular}


TABLE B.2.4. Series 2 Column 4 Effluent Composition (concentration units are ppm unless otherwise noted)

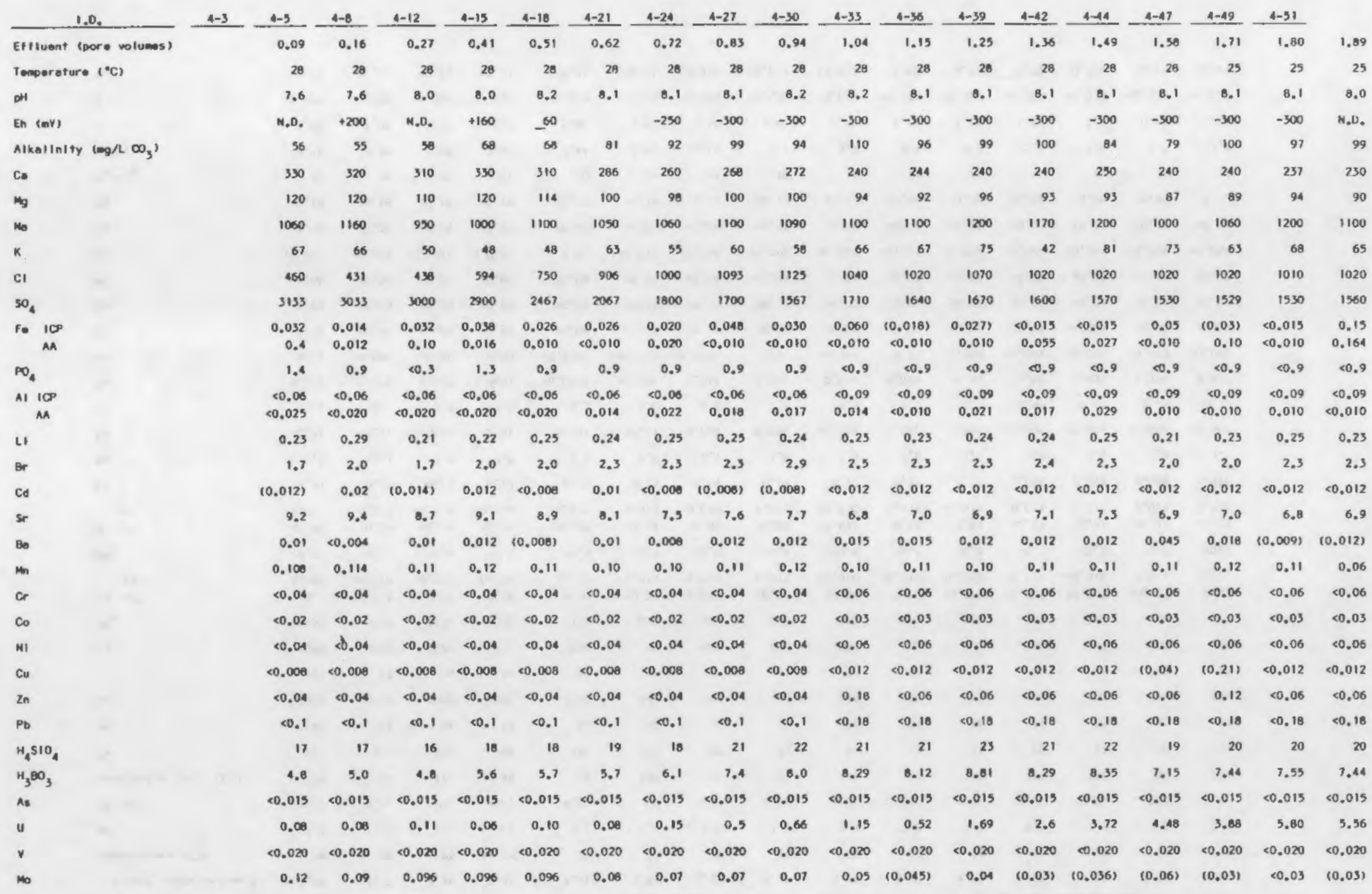

N.D. - not determined

(1) - Denotes auestionable value near detection limit 


\section{TABLE B.2.4. (contd)}

\begin{tabular}{|c|c|c|c|c|c|c|c|c|c|c|c|}
\hline 1,0, & $4-34$ & $4-57$ & $4-59$ & $4-61$ & $4-63$ & $-\infty-\infty$ & $4-60$ & $4=71$ & $4-73$ & $4-75$ & $4-78$ \\
\hline Ettluent (pore volumes) & 2.02 & 2.15 & 2.24 & 2.33 & 2,42 & 2.55 & 2.64 & $2 . n$ & 2.06 & 2.95 & 3.08 \\
\hline Temperature (c) & 25 & 25 & 25 & 23 & 25 & 25 & 25 & 25 & 25 & 25 & 25 \\
\hline مH & 0.0 & 8.0 & 8.0 & 8.0 & 8.1 & 8.1 & 8.1 & 8.1 & 0.1 & 8.1 & 8.1 \\
\hline En (mv) & -230 & N.O. & N.D. & -250 & -300 & -300 & -300 & -300 & -300 & -500 & -300 \\
\hline Alkotinity (ing $/ \mathrm{CO}_{3}$ ) & 84 & 110 & 130 & 92 & 100 & 92 & 110 & 86 & 110 & 110 & 120 \\
\hline$c_{0}$ & 235 & 230 & 243 & 230 & 234 & 235 & 237 & 240 & 224 & 245 & 2930 \\
\hline $\mathrm{Mg}$ & 92 & 95 & 96 & 95 & 93 & 96 & 90 & se & 89 & 93 & 93 \\
\hline Mo & 1000 & 1000 & 1000 & 1000 & 950 & 1000 & 900 & 860 & 050 & 870 & 870 \\
\hline $\mathrm{k}$ & 64 & 57 & 64 & $m$ & 65 & 79 & 63 & 37 & so & 31 & 57 \\
\hline ci & 1020 & 1020 & 1010 & 1040 & 1020 & 1020 & 1020 & 1010 & 1020 & 1010 & 1020 \\
\hline SO $_{4}$ & 1550 & 1570 & 1530 & 1530 & 1570 & 1490 & 1530 & 1530 & 1570 & $15 \times 0$ & 1570 \\
\hline Fo $\frac{100}{\mathrm{M}}$ & $\begin{array}{l}0.33 \\
0.34\end{array}$ & $\begin{array}{l}(0.03) \\
<0.010\end{array}$ & $\begin{array}{l}(0.02\} \\
<0.010\end{array}$ & $\begin{array}{l}(0.05) \\
00.010\end{array}$ & $\begin{array}{l}10.02) \\
<0.010\end{array}$ & $\begin{array}{r}0.05 \\
<0.010\end{array}$ & $\begin{array}{r}0.04 \\
<0.010\end{array}$ & $\begin{array}{l}0.18 \\
0.23\end{array}$ & $\begin{array}{r}0.05 \\
0.022\end{array}$ & $\begin{array}{r}0.06 \\
0.039\end{array}$ & $\begin{array}{r}0.05 \\
0.027\end{array}$ \\
\hline $\mathrm{PO}_{4}$ & $<0.9$ & $<0.9$ & $<0.9$ & $<0.9$ & $<0.9$ & $<0.9$ & $<0.9$ & $<0.9$ & $<.9$ & $<0.9$ & $<0.9$ \\
\hline $\begin{array}{ll}A 1 & 100 \\
& A \wedge\end{array}$ & $\begin{array}{r}<0.09 \\
<0.010\end{array}$ & $\begin{array}{r}<0.09 \\
<0.010\end{array}$ & $\begin{array}{r}<0.09 \\
<0.010\end{array}$ & $\begin{array}{r}<0.09 \\
<0.010\end{array}$ & $\begin{array}{r}20.09 \\
<0.010\end{array}$ & $\begin{array}{r}<0.09 \\
<0.010\end{array}$ & $\begin{array}{l}<0.09 \\
0.011\end{array}$ & $\begin{array}{l}<0,09 \\
0.014\end{array}$ & $\begin{array}{l}<0.09 \\
0.015\end{array}$ & $\begin{array}{r}(0.12) \\
0.020\end{array}$ & $\begin{array}{r}(0.18) \\
0.010\end{array}$ \\
\hline 4 & 0.22 & 0.22 & 0.22 & 0.20 & 0.19 & 0.21 & 0.18 & 0.17 & 0.16 & 0.17 & 0.17 \\
\hline ar & 2.3 & 2.0 & 2.0 & 2.5 & 2.3 & 2.0 & 1.8 & 2.3 & 25 & 2.0 & 2.0 \\
\hline Cd & $<0.012$ & $<0.012$ & $<0.012$ & $\infty .012$ & $<0.012$ & $<0.012$ & 0.012 & $<0.012$ & $\infty .012$ & $<0.012$ & $<0,012$ \\
\hline sr & 6.5 & 1.0 & 7.3 & 6.8 & 6.8 & 7.2 & 6.8 & 6.7 & 6.2 & 6.9 & 6.9 \\
\hline Ba & 0.012 & 0.012 & 0.012 & 0.012 & 0.012 & 0.012 & 0.018 & 0.018 & 0.015 & 0.018 & 0.021 \\
\hline m & 0.11 & 0.10 & 0.11 & 0.096 & 0.10 & 0.12 & 0.12 & 0.13 & 0.12 & 0.13 & 0.13 \\
\hline cr & $<0.06$ & $<0.08$ & $<0,06$ & $<0.06$ & $\infty .06$ & $<0.00$ & $<0.08$ & $<0.06$ & 80.06 & $<0.06$ & $<0.06$ \\
\hline$\infty$ & $<0,03$ & $<0.03$ & $<0.03$ & $<0.03$ & $<0.03$ & $<0,03$ & $<0,03$ & $<0,03$ & $<0.03$ & $(0.03)$ & $(0.03)$ \\
\hline NI & $<0.06$ & $<0.06$ & $<0.06$ & $<0.06$ & $<0.06$ & $<0.06$ & $<0.06$ & $<0.06$ & $<0.06$ & $<0.06$ & $<0.06$ \\
\hline $\mathrm{Cu}$ & $(0.024)$ & $<0.012$ & $<0.012$ & $(0.024)$ & $(0.027)$ & 0.027 & 0.033 & 0.042 & 0.024 & 0.03 & 0.04 \\
\hline $2 n$ & $<0.06$ & $<0.06$ & $<0.06$ & $<0.06$ & $<0.06$ & $<0.06$ & $<0.06$ & $<0.06$ & $<0.06$ & $\infty .00$ & $<0.06$ \\
\hline $\mathrm{Pb}$ & $<0.18$ & $<0.18$ & $<0.18$ & $<0.18$ & $<0.18$ & $<0.18$ & $<0.10$ & 40.18 & $<0,18$ & $<0.18$ & $<0.18$ \\
\hline $\mathrm{H}_{4} \mathrm{SIO}_{4}$ & 20 & 19 & 20 & 20 & 19 & 20 & 18 & 18 & 10 & 19 & 19 \\
\hline $\mathrm{H}_{3} \mathrm{BO}_{3}$ & 1.50 & 7.21 & 7.19 & 7.26 & 6.9 & 7,38 & 6.92 & 6.92 & 3.15 & 7.32 & 7.44 \\
\hline As & $<0.015$ & $<0,015$ & $<0,015$ & $<0.015$ & $<0.015$ & $<0.015$ & $<0.015$ & 0.015 & $<0.015$ & $<0.015$ & $<0.015$ \\
\hline u & 5.76 & 8.01 & 6.4 & 7.61 & 7.08 & 9.51 & 8.0 & 9.5 & 10.6 & 8.94 & 6.08 \\
\hline v & $<0,020$ & $<0.020$ & $<0.020$ & $<0.020$ & $<0,020$ & $<0.020$ & 0.020 & $<0.020$ & $<0.020$ & $<0.020$ & $<0,020$ \\
\hline to & $(0,036)$ & $<0.03$ & $<0.03$ & $<0.03$ & $<0.03$ & $<0.03$ & $(0.03)$ & $(0.03)$ & $(0.03)$ & 0.04 & 0.05 \\
\hline
\end{tabular}





\section{DISTRIBUTION}

No. of

Copies

OFFSITE

485 U.S. Nuclear Regulatory Commission

Division of Technical Information and Document Control

7920 Norfolk Avenue

Bethesda, MD 20014

E. F. Conti

NRC Office of Nuclear Regulatory Research

Washington, DC 20555

Mark Matthews

UMTRAP

DOE Albuquerque Operations Office P. 0. Box 5400

Albuquerque, NM 87115

Thomas Nicholson

NRC Office of Nuclear Regulatory Research

Washington, DC 20555

C. N. Ostrowski

NRC Office of Nuclear Regulatory Research

Washington, DC 20555

P. J. Garcia

NRC Office of Nuclear Material Safety and Safeguards

Washington, DC 20555

D. R. Tweeton

Twin Cities Research Center

Bureau of Mines

5629 Minnehaha Avenue South

Minneapolis, MN 55417

Dan Siefken

NRC Office of Nuclear Materials, Safety, and Safeguards

Washington, DC 20555
No. of

Copies

OFFSITE

K. L. Weaver

Radiation Control Division

Colorado Department of Health

$4210 \mathrm{E}$. 11th Avenue

Denver, C0 8D220

ONSITE

50 Pacific Northwest Laboratory

N. E. Bell

W. J. Deutsch (14)

M. E. Dodson

D. W. Dragnich

C. E. Elderkin

R. L. Erikson

M. R. Elmore

A. R. Felmy

M. G. Foley

J. S. Fruchter

G. W. Gee

J. N. Hartley

E. A. Jenne

D. R. Kalwarf

C. T. Kincaid

B. K. Marshall

W. J. Martin

B. W. Mercer

R. W. Nelson

B. E. Dpitz

P. R. Partch

R. W. Perkins

S. R. Peterson

R. J. Serne

J. W. Shade

D. R. Sherwood

J. A. Stottlemyre

V. T. Thomas

W. C. Weimer

N. A. Wogman

Publishing Coordination (2)

Technical Information (5) 
$38+8-90123914$

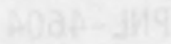

49

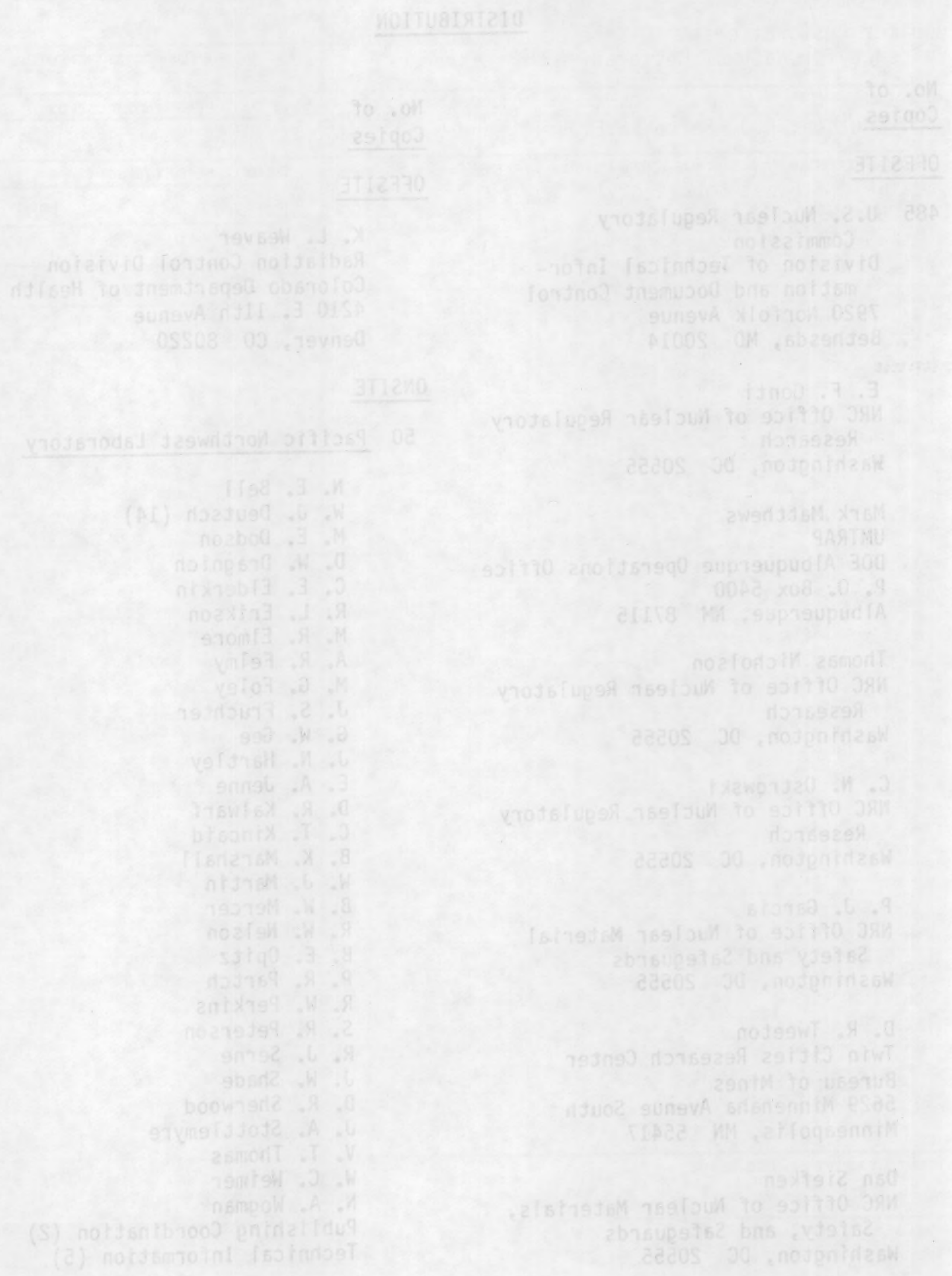




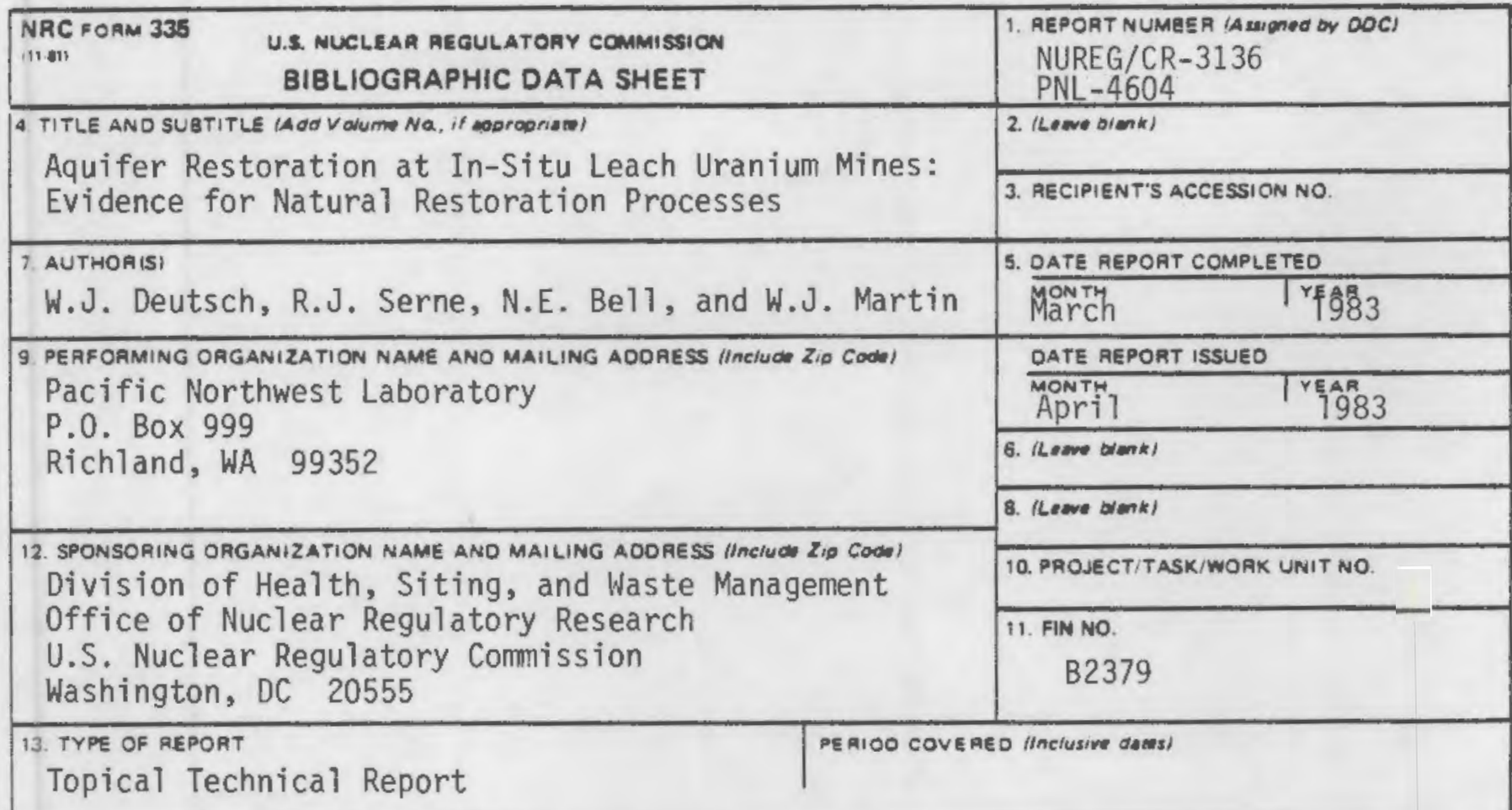

\begin{tabular}{|l|l|l}
\hline 15. SUPPLEMENTAAY NOTES & 14. (Lem ankJ)
\end{tabular}

18. ABSTRACT R00 words or lossi Pacific Northwest Laboratory conducted experiments with aquifer sediments and leaching solution (lixiviant) from an in-situ leach uranium mine. The data from these laboratory experiments and information on the normal distribution of elements associated with roll-front uranium deposits provide evidence that natural processes can enhance restoration of aquifers affected by leach mining. Our experiments show that the concentration of uranium (U) in solution can decrease at least an order of magnitude (from 50 to less than $5 \mathrm{ppm} \mathrm{U}$ ) due to reactions between the lixiviant and sediment. The concentrations of As, Se, and Mo in an oxidizing lixiviant should also decrease as a result of redox and precipitation reactions between the solution and sediment.

The lixiviant concentrations of major anions (chloride and sulfate) other than carbonate were not affected by short-term (less than one week) contact with the aquifer sediments. This is also true of the total dissolved solids level of the solution. Consequently, we recommend that these solution parameters be used as indicators of an excursion of leaching solution from the leach field.

17. KEY WOROS AND OOCUMENT ANALYSIS 17. OESCAIPTORS

Uranium Mining

In Situ Leaching

Geochemistry

Mine Restoration

Lixiviant Excursions

176. IDENTIFIERS: OPEN-EN DED TEAMS

18. AVAILABILITY STATEMENT

Unlimited

\begin{tabular}{|c|c|}
\hline $\begin{array}{l}\text { 19. SE CuRity CLASS IThis moont } \\
\text { Unclassified }\end{array}$ & 21 NO. OF PAGES \\
\hline 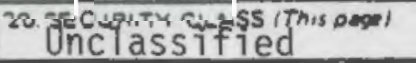 & $\begin{array}{l}\text { 22. PAICE } \\
\mathrm{S}\end{array}$ \\
\hline
\end{tabular}

NAC FORM 335 111-11 


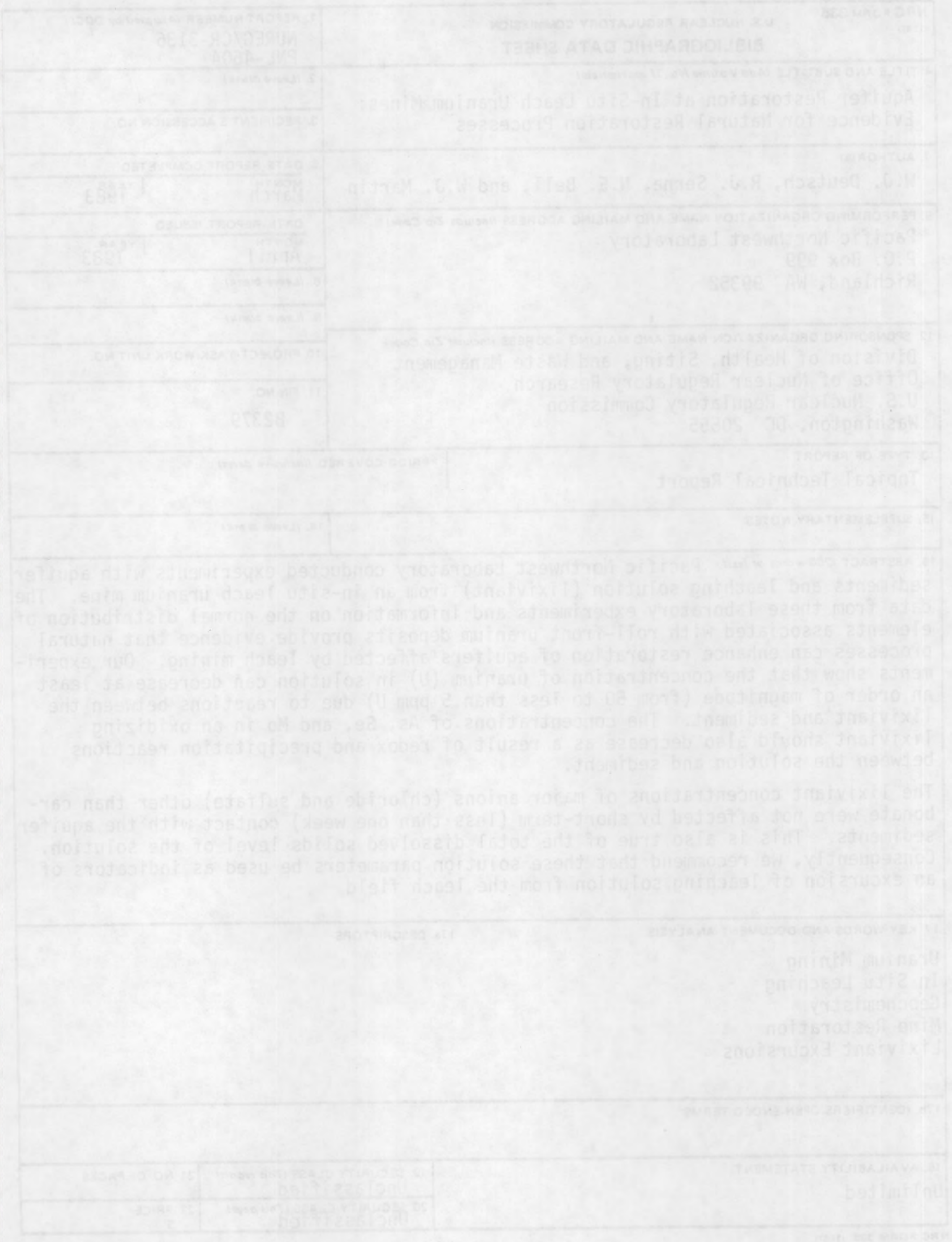

